ANATOLIA Anatolia Antiqua

ANTIQUA

Revue internationale d'archéologie anatolienne

XXIII | 2015

Varia

\title{
Marble Trade in Antiquity: Looking at Labraunda
}

\section{Agneta Freccero}

\section{(2) OpenEdition}

\section{Journals}

Electronic version

URL: http://journals.openedition.org/anatoliaantiqua/344

DOI: 10.4000/anatoliaantiqua.344

Publisher

IFEA

Printed version

Date of publication: 1 June 2015

Number of pages: 11-54

ISBN: 9782362450600

ISSN: 1018-1946

\section{Electronic reference}

Agneta Freccero, " Marble Trade in Antiquity: Looking at Labraunda », Anatolia Antiqua [Online], XXIII |

2015, Online since 30 June 2018, connection on 18 December 2020. URL : http://

journals.openedition.org/anatoliaantiqua/344 ; DOI : https://doi.org/10.4000/anatoliaantiqua.344

Anatolia Antiqua 


\title{
ANATOLIA ANTIQUA ESKI ANADOLU
}

\author{
XXIII
}

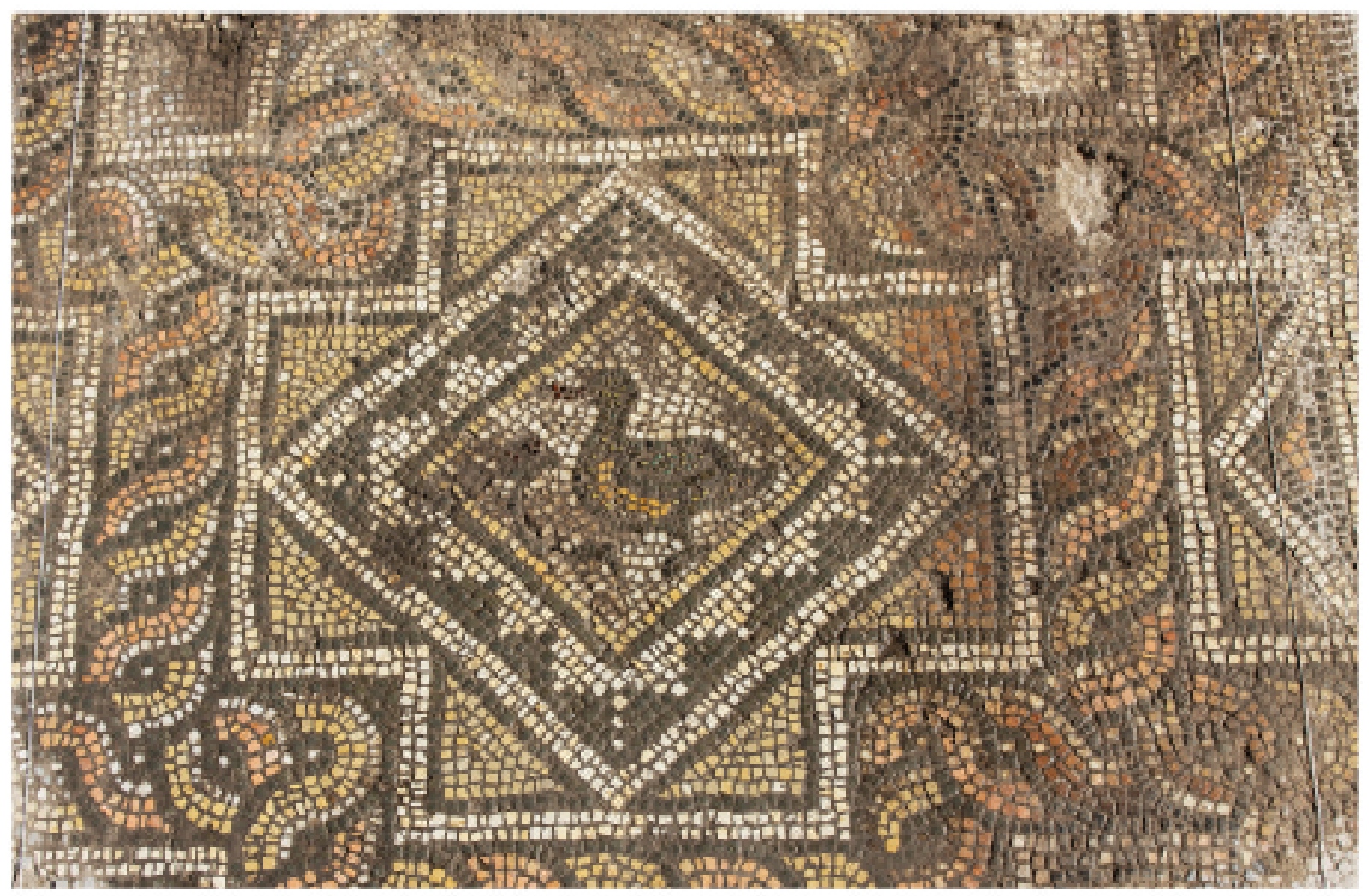

INSTITUT FRANC̣AIS D'ETUDES ANATOLIENNES GEORGES-DUMEZIL CNRS USR 3131 


\section{TABLE DES MATIERES}

Hélène BOUILLON,

On the anatolian origins of some Late Bronze egyptian vessel forms

Agneta FRECCERO,

Marble trade in Antiquity. Looking at Labraunda

Şehnaz ERASLAN,

Dionysus and Ariadne in the light of Antiocheia and Zeugma Mosaics

Ergün LAFLI et Gülseren KAN ŞAHIN,

Middle Byzantine ceramics from Southwestern Paphlagonia

Mustafa AKASLAN, Doğan DEMIRCİ et Özgür PERÇİN en collaboration avec Guy LABARRE, L'église paléochrétienne de Bindeos (Pisidie)

Anaïs LAMESA,

La chapelle des Donateurs à Soğanlı, nouvelle fondation de la famille des Sképidès

Martine ASSENAT et Antoine PEREZ,

Localisation et chronologie des moulins hydrauliques d'Amida. A propos d'Ammien Marcellin,

XVIII, 8,11

Helke KAMMERER-GROTHAUS,

$»$ Ubi Troia fuit«

Atzik-Köy - Eine Theorie von Heinrich Nikolaus Ulrichs (1843)

CHRONIQUES DES TRAVAUX ARCHEOLOGIQUES EN TURQUIE, 2015

Sami PATACI et Ergün LAFLI,

Surveys in Ardahan on the turkish-georgian borderline in 2013 and 2014

Çĭ̆dem MANER,

Preliminary report on the second season of the Konya-Ereğli survey (KEYAR) 2014

Dominique BEYER, Can KARAVUL, Françoise LAROCHE-TRAUNECKER et Aksel TiBBET,

Rapport préliminaire sur les travaux de la mission archéologique de Zeyve Höyük-Porsuk 2014

Jean-Charles MORETTI avec la collaboration de Nicolas BRESCH, Isabel BONORA,

Jean-Jacques MALMARY et Olivier RISS,

Claros, le temple d'Apollon : travaux réalisés en 2014

Olivier HENRY et Erika ANDERSSON, Christophe BOST, Ömür Dünya ÇAKMAKLI, Angela COMMITO, Mélissa CORMIER-HUGUET, Peter DE STAEBLER, Pierre DUPONT, Duygu ERGENÇ, Axel FREJMAN, Banu KEPENEK, Pascal LEBOUTEILLER, Haral NILSSON, Felipe ROJAS, Baptiste VERGNAUD, 


\section{MARBLE TRADE IN ANTIQUITY: LOOKING AT LABRAUNDA*}

\section{INTRODUCTION}

What is the provenance of the marble used at Labraunda? According to tradition, marble was supplied by quarries at Sodradag at the feet of which Mylasa, the ancient capital of Karia, was laid out. Strabo reports that Mylasa was known for its many buildings of white marble, and he suggests that such marble might have been used at Labraunda too ${ }^{1}$. Antique quarries identified at the southern slopes of Mount Sodra contribute to the proposition that Sodra provided marble for Labraunda. However, ocular inspection suggests there are at least three types of marble at the site. Could three different kinds of marble have been quarried at Sodradağ? Yes, it is possible, because quarries in any mountain can provide different kinds of stones. But there are many ancient quarries in the vicinity, as for example at Euromos, Stratonikeia and Herakleia on Latmos. It can therefore not be excluded that some blocks were brought from Mount Sodra and other elements were imported from quarries further away, and that such trade may be linked to periods in time. Furthermore, it is probable that one type of marble was preferred for sculpture, another for finely cut inscriptions and architectonic elements while yet another quality was used for columns, bases and anta blocks; these marbles may have different origins. I assume that the Karian kings would choose what was considered the very best for each purpose, rather than to choose the nearest available product because the transport was easier and cheaper. The ruling dynasts did not care for the costs when one objective was to make an impact on the people. The present study was made to establish the origin of the Labraunda marbles and the possible existence of ancient transport roads that would have enabled marble trade in antiquity (Fig. 1-2).

\section{BACKGROUND}

Ocular observations during surveying and conservation in 2011-2012 indicated that there were at least three kinds of marble at the sanctuary of Labraunda. Most characteristic was a coarse-grained white marble which often had veins of large calcite crystals. The second distinctive type was white and fine-grained and the third was fine-grained pale grey $^{2}$ (Fig. 3). There are some less distinct marbles too, possibly variations of those mentioned above. I made a first attempt to see if there was any connection between marbles found at Mount Sodra and Labraunda in 2010, and four samples randomly obtained were analysed at CNR/ICVBC in Florence in $2011^{3}$. Two of these samples were obtained at Labraunda - one coarse-grained white, Labranda white, and one finegrained pale grey, Labraunda grey, and two small pieces were brought from a pre-modern quarry at Sodradağ, Sodra white, and Sodra black. According to analyses Labraunda grey and Sodra white were very similar, and the characteristic large-grained Labraunda white was of a different type ${ }^{4}$. Sodra

\footnotetext{
*) Acknowledgements: My sincere thanks go to the former excavation Director Lars Karlsson who invited me to plan the marble conservation project at Labraunda, and to the present Director Olivier Henry who introduced me to professionals of great importance for the marble study, both of whom permitted and supported this research project. Special thanks go to Anneliese Peschlow-Bindokat for sharing information and showing the ancient Herakleia/Miletos quarries, to Åke Olson who accompanied me in search for quarries, to Emma Cantisani, Donato Attanasio and Walter Prochaska for stimulating and important discussions on the marbles, and to Pontus Hellström for valuable comments and information regarding Labraunda. My deep gratitude goes to the Swedish Academy of Letters, History and Antiquities, Stiftelsen Längmanska Kulturfonden, and to Helge Ax:son Johnsons stiftelse, for financing this research.

1) Strabo XIV, 658 .

2) Freccero 2013: 324f.

3) Consiglio Nazionale delle Ricerche/Istituto per la Conservazione e Valorizazione dei Beni Culturali.

4) The methods applied were mineralogical and petrographic analyses.
} 

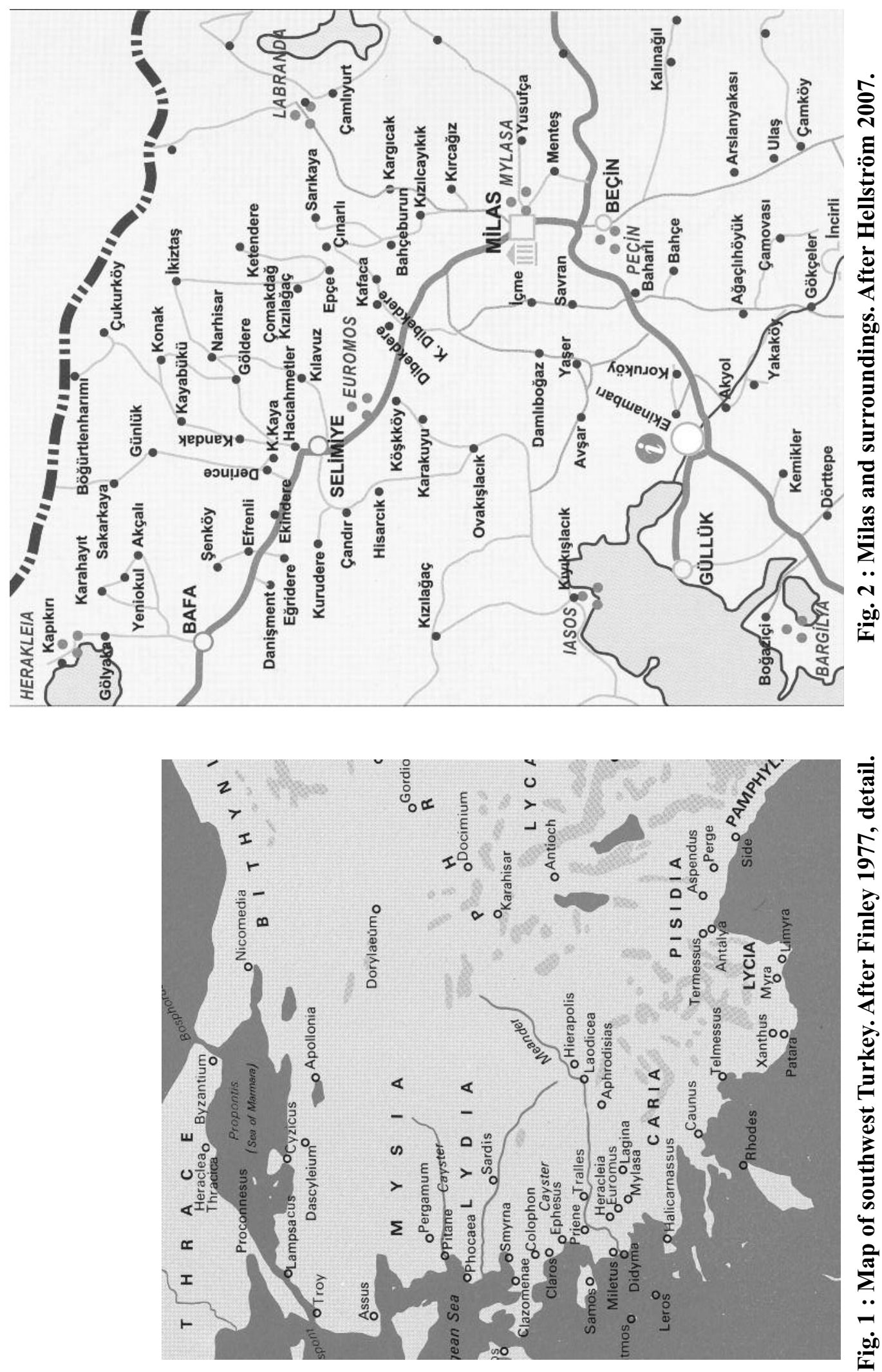


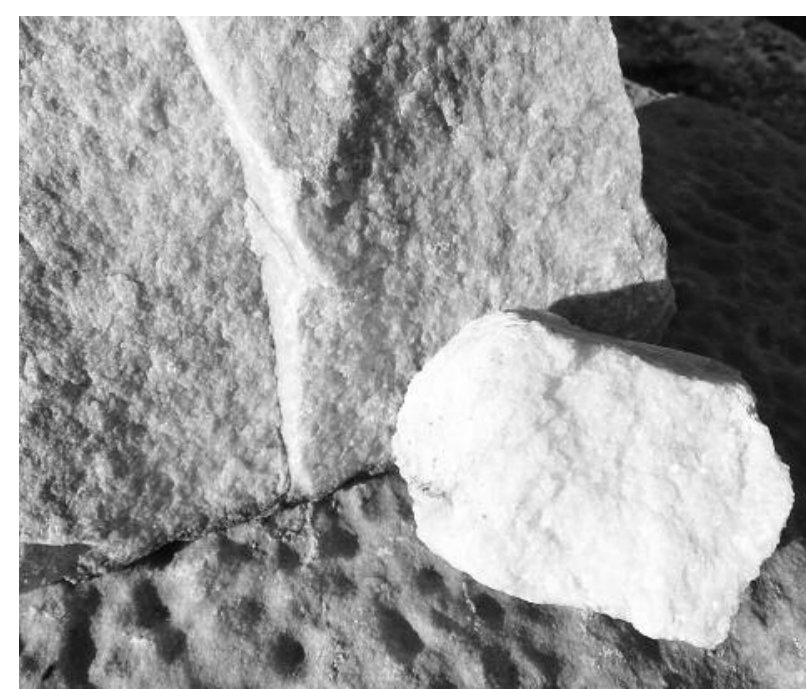

Fig. 3 : Coarse-grained white and fine-grained pale grey marble from Labraunda (Photo A.F.).

black was not expected to be similar to the marbles, but analysed to determine its components. The following year I sampled five datable objects at Labraunda. Three were obtained from architectural fragments dated to the Hekatomnid period, LabA3, LabC42, and $\mathrm{LabCol}$, and two from Corinthian capitals of the Roman period LabCorcap 1 and LabCorcap $2^{5}$. A fifth sample, MaTo, was taken at the subterranean marble tomb situated along the Sacred Way between Labraunda and Milas, near the village of Kargicak. The results showed that the marbles of the Hekatomnid period were quite similar but not identical, and the Corinthian capitals were of another kind. The extremely fine-grained greyish marble from the marble tomb was totally different. It thus became possible to distinguish three preliminary groups; one contained coarse-grained white marble (Labraunda white, $L a b A 3$, LabC42, LabCol), the second held marbles used for the Corinthian capitals (LabCorcap 1 and Corcap 2) and a third group, so far, contained finegrained white marble from Sodra and grey marbles from Labraunda and Kargicak. At this point I planned to make a regular marble study and applied for funding, which I was happy to receive.

\section{LABRAUNDA AND THE HEKATOMNIDS}

The Hekatomnids, as satraps appointed by the Persian king and natives of Karia, manifested their wealth and power in an extensive building programme. The founder of the dynasty, Hekatomnus, ruled from the capital Mylasa and began monumentalizing the ancient Sanctuary at Labraunda by building a temple to Zeus with the double axe $e^{6}$ known as Zeus of the Armies ${ }^{7}$, Zeus of Karia, or the God of War ${ }^{8}$. At his death, he was succeeded by the eldest son Maussollos, who not only continued the building programme at Labraunda, but also moved the capital from inland Mylasa to seaside Halikarnassos, today's Bodrum. The originally Greek settlement was rebuilt into a splendid city with a strategic position that gave easy access to the Persian Empire as well as to Greece and the Aegean world. When Maussollos died in 353 , he left the empire to his wife ${ }^{9}$. She is closely connected to one of the most important buildings of the period, the Mausoleum at Halikarnassos, which probably was begun by Maussollos and completed by Artemisia in honour of her husband; it was so remarkable it was considered one of the Seven Wonders of the Ancient World ${ }^{10}$. Artemisia was succeeded by the younger brother Idrieus. According to earlier interpretations, Idrieus continued the extensive building activity at Labraunda during his reign, but recently, Pontus Hellström has argued that Idrieus continued or was in charge of the dynastic project at Labraunda during the satrapy of Maussollos, and that the vast building programme was completed when he himself became satrap and moved to Halikarnassos ${ }^{11}$. At his death in 344 his wife and sister Ada took over ${ }^{12}$. Only a few years later she was banished by the youngest brother Pixodaros. Ada retreated to Alinda, where she remained until Alexander the Great reinstated her on the throne in $334^{13}$.

The Hekatomnids had special needs for a representative city where art and architecture underlined the importance of the family ${ }^{14}$. They had roots in Karian tradition and cultural affiliation to Greece as well as to Persia, a combination that eventually resulted in a new fashion in art and architecture,

5) The prefix $L a b$ was added later in order to clearly distinguish the Labraunda samples from samples obtained at other sites and quarries. $L a b A 3$ and $L a b C 42$ refer to inventory numbers and $\mathrm{LabCol}$ to a column. All further information is available in the schedules.

6) Hekatomnos ruled the Karians from 397-377.

7) Herodotos mentions that Karians were the only people who worshipped Zeus by this name.

8) Aelian, On Animals XII.30.

9) Maussollos ruled 377-353 and Artemisia 353-351.

10) Strabo 14.2.16.

11) Hellström 2015, forthcoming.

12) Idrieus ruled $351-344$, Ada $344-340$

13) Strabo 14.2.17.

14) Pedersen 2013: 43 
known as the Ionian Renaissance ${ }^{15}$. The earliest evidence of this new style is the combination of Ionian and Doric orders in the buildings called Andrones at Labraunda ${ }^{16}$. Structures and elements in the Hekatomnid style in East Greek architecture remain in Milas, Amyzon, Iasos, Kaunos and Ephesus ${ }^{17}$.

Olivier Henry stresses that the striking Hekatomnid architecture was not an entirely new invention but a revival of Karian tradition as seen in monumental tombs of the $6^{\text {th }}$ century ${ }^{18}$. One example of smaller dimensions is a subterranean marble tomb along the ancient Sacred Road between Mylasa and Labraunda, close to the village of Kargicak. Another example is found at Beçin, where ancient structures have been interpreted as the foundations of a temple. Henry suggests that the remnants are not of a temple, but of a monumental tomb like the Mausoleum and the recently discovered Uzun Yuva at Milas ${ }^{19}$. This particular period in time was, as Pedersen points out, characterized by a cultural mix and economic prosperity which gave growth to artists and architects who created some of the monuments considered among the Seven Wonders of the Ancient World; the Mausoleum, the Colossus at Rhodes, the Artemision at Ephirus and the Pharus at Alexandria ${ }^{20}$.

The Hekatomnids were powerful and wealthy rulers; they moved from Mylasa and made a splendid new capital at Halikarnassos and a lavish sanctuary at Labraunda. They generated a new style, in which Eastern and Western elements were combined. What kind of marble would be appropriate for the decoration of these buildings, and from where was it ordered?

\section{ANCIENT QUARRIES, QUARRYING, AND MARBLE TYPES}

Which were the quarries in the region? Many highly valued marbles were quarried in Anatolia and on islands in the Aegean Sea ${ }^{21}$. According to Pliny, sculptors were known to work here already before Cyrus had come to the throne in Persia, and they only worked in marble from Paros until later when other white marbles had been found; the white marble par excellence was quarried in subterranean galleries $^{22}$. There was a less appreciated, slightly grey marble as well, called Paros $2^{23}$. The characteristics which made the Parian marble so cherished were its transparency and candid white hue. Another highly valued stone was quarried at the island of Thasos. Like the Parian, it is a relatively largegrained marble with a slightly creamy white hue. In the Roman period the Thasian marble was so much appreciated that the island became one of the main sources of stone.

Other important quarries were located along the coast. Among these was Herakleia on Latmos, situated on a hill at Lake Bafa, which had formerly been part of the sea. Along the south shore of the lake were two extended quarry areas, where marble had been extracted from at least the $6^{\text {th }}$ century B.C. ${ }^{24}$. These mines are now called Herakleia and Miletus quarries, the latter of which provided marble for the temple of Apollo at Didyma ${ }^{25}$. There is a difference between these marbles; the Herakleia quarries provided a coarse-grained white stone while Miletus marbles have finer grains and are rarely pure white ${ }^{26}$. In spite of petrological differences, these marbles have proved to be isotopically and spectroscopically quite similar, and can therefore be collectively identified as Heraklean marble ${ }^{27}$. Another seaside town in the district was Iasos, where there were minor areas of white stone, but the veined red marble, known as cipollino rosso had made Iasos famous ${ }^{28}$.

Inland quarries provided well-known marbles as well. There were quarries at Mylasa, Stratonikeia, Aphrodisias and Docimium, just to mention a few. Strabo tells us that Mylasa "has a most excellent quarry of white marble. Now this quarry is of no small advantage since it has stone in abundance and close at hand for building purposes and in particular for the building of temples and other public works. Accordingly, this city, as much as any other, is in

15) Henry 2013b, Karlsson 2013, Pedersen 2013.

16) Karlsson 2013.

17) Pedersen 2013: 43.

18) Henry 2013: $81 \mathrm{ff}$.

19) Henry 2014: 73.

20) Pedersen 2013: 44f.

21) On white marbles, see e.g. Pensabene 2002b, and Borghini (ed.) 1998.

22) Pliny $36.8 ; 36.14$

23) Pensabene 2002b: 212.

24) Vitruvius 10.7.15; Monna and Pensabene 1997: 124.

25) On the Miletus and Herakleia quarries see Peschlow-Bindokat 1981.

26) Pensabene 2002b: 214f

27) Attanasio 2006: 190.

28) Monna and Pensabene 1977: 123ff; Marchei 1998: 207. 
every way beautifully adorned with porticoes and temples"29. Antique marble quarries close to Milas were, in fact, identified by Monna and Pensabene. They sampled in two areas, one of which was $2 \mathrm{~km}$ south of Milas (Milas S) and the other on the eastern slope of Sodradağ (Milas N) ${ }^{30}$. Analyses revealed there were some differences between the districts; samples labelled Milas S were grey, grey-black, veined grey or white with fine grains, or white with large grains, and samples labelled Milas $\mathrm{N}$ had larger grains.

On the plain northwest of Milas and below Labraunda is the archaeological site of Euromos, where nearby quarries presumably provided marble for the temple of Zeus and other monuments. Durosoy and Altınöz mentions marble quarries in the mountains close to Labraunda, but no such quarries have been identified and published so far $^{31}$. East of Labraunda is Stratonikeia which according to Strabo was adorned with costly buildings and two temples, the most famous of which was that of Hekate at Lagina ${ }^{32}$. Further east into the land is Aphrodisias, a town that had founded its wealth on marble quarrying, cutting, sculpting and trade ${ }^{33}$. Close to the ancient town were around fifteen areas that provided different types of marbles. Some were uniform white with medium large grains, others white with grey-blue veins and medium or large crystals ${ }^{34}$. The Aphrodisian marble was much appreciated for sculpture due to its slightly transparent and homogeneous whiteness, which sometimes tended towards grey or yellow. There were, in addition, occasional areas with veins of grey marble too, and the variation in colour was exploited by Aphrodisian sculptors, who were known as skilled in combining pieces of grey and white marble in statues ${ }^{35}$.

Beside all these Anatolian and Aegean marbles, there were two major sources of marble in Greece as well; Mount Pentelicon and Mount Hymettos. Pentelic marble is a fine-grained warm-white marble, and the Hymettan is veined greyish white marble, particular because of the bitumen smell as it is cut ${ }^{36}$. The foul and characteristic smell is due to gases inside the stone which are freed when the stone is broken or $\mathrm{cut}^{37}$. In the Roman period, the desire to have outstanding qualities of marble led to the opening of quarries even in disadvantaged positions, such as at Docimium ${ }^{38}$.

Marble was quarried and sculpted in Greece and in Asia Minor already in the Bronze Age, but the technique seems to have been lost for centuries after the collapse of the Mycenaean civilization, until it came to use again in the $7^{\text {th }}$ century B.C. ${ }^{39}$. It is commonly thought that the Archaic Greece had its knowledge in stone-working from Egypt, but according to Waelkens, the Greek were from the very beginning more advanced in techniques and equipment, therefore suggesting the knowledge was imported from Anatolia ${ }^{40}$. Pliny, in fact, believed that the art of cutting marbles into thin slabs was possibly invented in Karia. The earliest example he could think of was the palace at Halikarnassos, where the brick-walls were decorated with Proconnesan marble ${ }^{41}$.

The most desired marble in antiquity was quarried in subterranean galleries at Paros. Galleries were, however, exceptions and open quarries, formed as gigantic steps on hillsides, were the rule ${ }^{42}$. These characteristic formations are still visible, and are, together with deposits of waste materials, unfinished sculpted materials and iron tools, evidence of a former quarry and the coarse work which was normally carried out before the half-finished product left the site. Abandoned architectural elements can be found in every single quarry, and in some there are colossal sculptures and sarcophagi as well ${ }^{43}$. Working traditions are not the same everywhere, and by studying the organization of work and technical approach it has been possible to deduce how marble was extracted and with which tools under different periods of time ${ }^{44}$. Many components

29) Strabo 14.2, 23.

30) Monna and Pensabene 1977: 117-119.

31) Durosoy and Altınöz 2012: 350.

32) Strabo 14.2.25.

33) Pensabene 1998

34) Pensabene 2002b: 217.

35) Brody 2007: 95.

36) Marchei 1998: 251, 249.

37) Prochaska et al. 2012: 231

38) Bruno 2002: 181.

39) Waelkens et al. 1988: 88.

40) Waelkens et al. 1988: 89

41) Pliny $H N 36.48$.

42) Rockwell 1993: 80.

43) Waelkens et al. 1988: 110.

44) Nylander 1970: $20 \mathrm{ff}$. 
intended for the temple at Didyma were abandoned in the Miletus quarries, where they still remain. Some were left on the south shore of Lake Bafa too, where eighteen roughly worked column drums have been found ${ }^{45}$. Evidence of prefabrication and different levels of finishing is illustrated on marble cargo found in ships that were lost at sea, such as the marble carrier that sank near Kızılburun in Asia Mi- nor ${ }^{46}$. Research show that the small sized ship carried roughly worked half-finished column drums and a Doric capital of Proconnesan marble; the destination was the Temple of Apollo at Claros. Many wrecks of the Roman period have been found along the Italian coast, and today submarine excavations provide plenty of information about the marble trade $^{47}$ (Fig. 4-5).

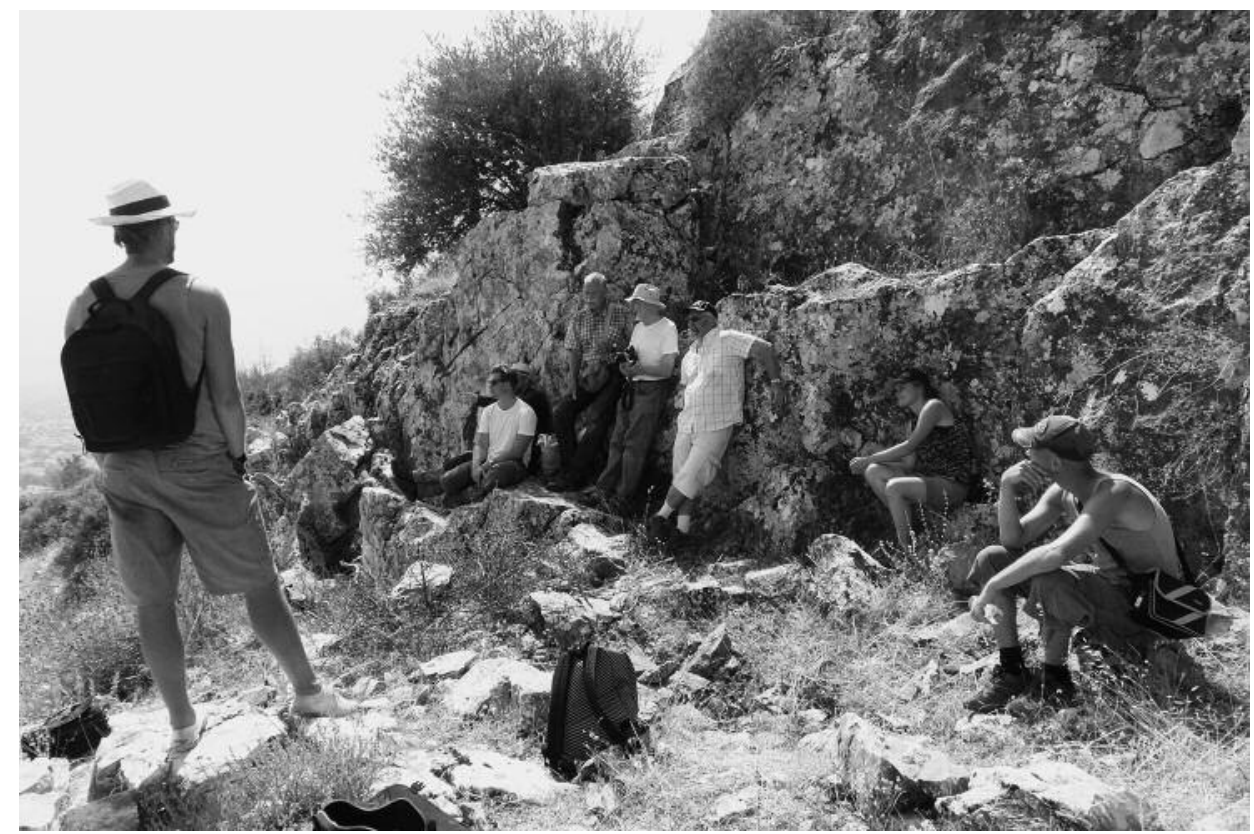

Fig. 4 : Marble quarry at Sodradağ (Photo A.F.).

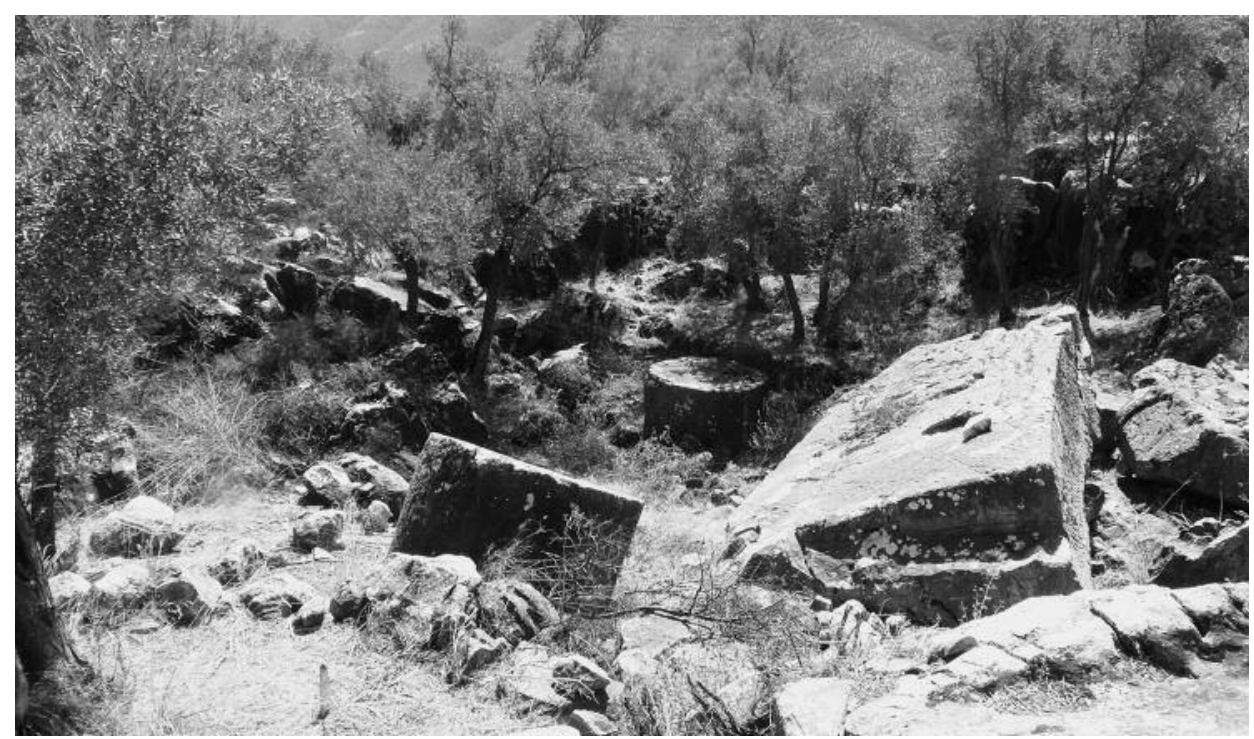

Fig. 5 : Marble quarry at Herakleia on Latmos (Photo A.F.).

45) Peschlow-Bindokat 1981: 186.

46) Carlson et al. 2010: 145-153.

47) Pensabene 2002a: 14ff; for the list of shipwrecks and their cargo, see also Carlson et al. 2010. 


\section{MARBLE TRADE, TRANSPORT, AND COSTS}

There were many marble quarries in the region, but which transport and trading possibilities were at hand? The systematic organization of quarrying and trade was not fully developed until the Roman Imperial era when quarries were turned into Imperial ownership. But techniques of lifting and to control transport down as well as up the mountains had been developed at a much earlier date and colossal blocks of marble were transported long distances from quarries to building sites.

Goods were, in the archaic period, mainly transported by rivers or at sea. Land transport, which was much more difficult and time-consuming, was developed later ${ }^{48}$. But, important mountain routes in Central Anatolia had been laid out already in the middle of the $3^{\text {rd }}$ millennium B.C.; the 'Great Caravan Route' between Cilicia and Troy was established in the early Bronze Age ${ }^{49}$. By the rise of the Hittite Kingdom in the $16^{\text {th }}$ century B.C. there were fortified administrative centres and store-houses at regular distances ${ }^{50}$. Processional roads were stone-paved around 1200 B.C., as revealed by the two km long procession road from the main temple at Hattusas to the sanctuary ${ }^{51}$. Other procession roads have been identified at Assur, Babylon and Uruk ${ }^{52}$. Further evidence of transport and trade is that a consistent traffic policy was developed by the Persian King in order to control the empire ${ }^{53}$. This means that the Aegean world had a trade network encompassing the Anatolian coast, the islands and mainland Greece ${ }^{54}$. By the time of Alexander there were even signal systems along important roads ${ }^{55}$. Strabo gives a long account for the roads in Caria, starting with the distance from Physcus to the Meander along the road to Ephesus, which amounted to 1180 stadia. From the Meander along the coast of Ionia to Tralleis were 80 stadia, then to Magnesia 140, to Ephesus 120 and so on, continuing to Cappadocia ${ }^{56}$.
How were the roads in the region of Mylasa and Labraunda? Strabo tells us that "...there is a paved road of almost sixty stadia from the shrine to Mylasa, called the Sacred Way, on which their sacred processions are conducted". Aelian estimated the distance to seventy stadia, that is, roughly $13 \mathrm{~km}^{57}$. Stonepaving a long procession road indicates a local capacity of constructing adequate transport roads as well. Labraunda is situated on a mountain, overlooking the valley. The transport of heavy marble up to the level of the sanctuary was most certainly slow and more difficult than transport on the plain. A recent study principally deals with the cultural accumulation constructions along this cultural road, which was stone-paved by the Hekatomnids to ease the transportation of building materials to Labraunda ${ }^{58}$. Transport issues such as costs and quantities of materials in connection to the Sanctuary of Labraunda have not been investigated, but conditions at Herakleia have been carefully studied.

The transport distance from the quarries at Herakleia to the construction site of the Temple of Apollo at Didyma was approximately $30 \mathrm{~km}$; main part of the distance was carried out by sea and only about $7 \mathrm{~km}$ by land ${ }^{59}$. Documents regarding the construction of the Temple contain calculations on the costs of quarrying including rough cutting, transport and work at the construction site. It has been estimated that about one third each of the money available for the temple construction was used for work in the quarries, transport and work at the temple ${ }^{60}$. When the blocks had been extracted and the rough form had been worked at the quarries, they were transported on rollers and wooden sledges down to the harbour, shipped to the harbour of Panormos and again placed on sledges drawn by oxes and brought to Didyma ${ }^{61}$. The shapes of architectural elements were not completed until the blocks were finally located at the building site. The weight of some of these architectural elements has been calculated, and one of them, a threshold, weighs

48) On quarrying techniques and transports see e.g. Bruno 2002, Forbes 1965, Niewoehner et al. 2013a, Nylander 1970, Ortolani 1998, Peschlow-Bindokat 1981, Peschlow-Bindokat 1994, Rockwell 1993, Waelkens et al. 1988.

49) On the Great Caravan Route see Efe 2007.

50) Ökse 2007: 41.

51) Forbes 1965: 136; Andrae 1941.

52) On ancient processional roads see Andrae 1941.

53) Forbes 1965: 133.

54) Ökse 2007: 61.

55) Diodorus XIX 57,5.

56) Strabo 14.2.29.

57) Hellström 2007: 39.

58) Durosoy and Altınöz 2012: $342 \mathrm{ff}$.

59) Peschlow-Bindokat 1994: 130f.

60) Peschlow Bindokat 1994: 130f; Ortolani 1998: 28

61) Peschlow-Bindokat 1981: 160ff. 
almost 47 tons, which indicates a highly developed system for transporting heavy goods ${ }^{62}$.

Similar calculations of costs have been made in Macedonia $^{63}$. Architectural elements such as columns, capitals, and bases were prefabricated, transported to the coast and kept in storage until they were finally transported to their final destinations within the Roman Empire ${ }^{64}$. Documents of the Roman period show that not only the transport conditions were considered, but also the value attached to the material, as is evidenced by the great price difference in the Diocletian era between the same quantity of grey granite, which cost 100 denari and porphyry 250 denari ${ }^{65}$. Both kinds of stones had to be transported through the desert, on the River Nile and by ship over the sea.

\section{RECENT RESEARCH ON MARBLES}

Two recent marble investigations are of particular importance in the present context, because both regard this region. Thomas Cramer applied a multivariate approach on marble objects in Berlin to the determination of the material's provenance in Mediterranean and Anatolian marble areas ${ }^{66}$. His research regards the formations of marbles in the western part of the Menderes massif to which the mountains around Milas as well as Stratonikeia, Euromos, Miletos and Herakleia belong ${ }^{67}$. Cramer points out that all marble extracted in the south part of the Menderes massif is called Milas marble, independently of its colour and chemical composition which varies between quarries ${ }^{68}$. In general, the marble at Milas itself is identified as fine-grained. Another important investigation was made by a Turkish team who studied the Triassic marbles in the Muğla region in the south part of the Menderes massif ${ }^{69}$. The group particularly investigated marbles from quarries at Çayboyu (ÇM) and Kestanecik (KM), situated north and south of the town Kavaklidere. They found that both sites had lenses with seven different layers of marble, at which chemical composition as well as grain size differed slightly ${ }^{70}$. The ÇM and KM marbles are known as Muğla marble and Milas marble respectively, and both types appear in a variety of colours and patterns. Milas marbles are fine to coarse grained and some contain Dolomite crystals. In the present investigation, the focus is set on white marbles which might originate from Milas or perhaps some other quarries in the Menderes massif. It is, however, important to remember there are variations in the quarries in each district.

Another important study regards the marbles used at the Mausoleum at Halikarnassos ${ }^{71}$. When the study began, it had been assumed the all marble used for the monument would have come from the nearby island Cos, but the result of investigations showed that none of the marble blocks investigated were. Instead several different sources had been exploited, and the selection of stone was related to its function in the monument. The freestanding sculptures of Maussollos and Artemisia, and the lions at the roof, were made of Pentelic marble. Some portrait heads were of Parian marble, the Amazon frieze of Proconnesian marble and other elements of an undefined stone. Analyses show that marble from Mylasa or Herakleia most likely had been used for the Mausoleum's upper courses ${ }^{72}$. Considering the fact that the Mausoleum as well as the early buildings at the Sanctuary of Labraunda had been contemporaneously constructed by the same family, it would not be unreasonable to assume that different marbles had been used at Labraunda too.

Halikarnassos and Herakleia were coastal towns. Mylasa on the other hand, was situated in the inland, surrounded by large mountains. Therefore, main part of the long transport from Mylasa to Halikarnassos was by land, which was more difficult, expensive and time-consuming than by sea. On the other hand, the Hekatomnids had possession of the marble mountains at Mylasa, which of course was a matter of convenience too. As Mylasan marble presumably had been used at Halikarnassos, there must have been a suitable transport road, and if marble could be transported in one direction, it might have been transported in the other direction as well. At this

62) Ortolani 1998: 26.

63) Niewoener at al. 2013: 103, 107.

64) Waelkens et al. 1988: 109f.

65) Barresi 2002: 77.

66) Cramer 2004

67) On the extension of stone and marble in the Menderes massif, see Cramer 2004: $135 \mathrm{ff}$.

68) Cramer 2004: 148

69) Bağc1 et al. 2010.

70) Bağc1 et al. 2010: 39-55.

71) Walker and Mattews 1988: 117ff; 1997: 50.

72) Walker and Matthews 1997: 56. 
time existed the broad paved road from Labraunda to Mylasa ${ }^{73}$.

There are many examples on projects aiming at the determination of marbles used for Classical Greek, Hellenistic, and Roman sculpture. One project aims at the determination of different kinds of marbles used in Ephesian architecture and sculpture, by using a set of analytic methods such as those mentioned above, with the addition of chemical analysis of inclusion fluids and extractable salts ${ }^{74}$. Another important marble investigation concerns the Aphrodisian marbles from the Göktepe quarries, which was used for the Roman copies of the Little Barbarians of the Attalid dedication in Athens ${ }^{75}$. Focus in yet another study was set on the Docimium marble used for the Capitoline Gauls and other Roman replicas of Attalid sculpture ${ }^{76}$. Isotopic analysis was also employed to determine the origin of marble fragments used for bar counters in Pompeii ${ }^{77}$.

As pointed out by Donato Attanasio, the identification of quarries is essential if we want to understand important issues such as the range of commercial relationships and the trade routes pursued in antiquity, and also to recognize technological distinctions and changing taste ${ }^{78}$.

\section{MARBLE INVESTIGATION AT LABRAUNDA}

Preliminary results had shown that there were different kinds of marbles at Labraunda, and there was a relation between one fine-grained marble at Labraunda and one from a quarry at Mount Sodra. But did different quarries at Sodra provide different marbles, and, from where was the coarse-grained white marble? Another question regarded marbles of the Roman and later periods - was marble reused or was fresh marble imported for these constructions? Some buildings at Labraunda and a few quarries were sampled as well.

Sampling started at Labraunda. Archaeologists in the team were asked to indicate a few architectural elements of particular importance in their excavation area, thereby ascertaining a selection of relevant objects which represent the different building phases at the site, from the Hekatomnid period to Late Antiquity. Then, some pre-modern quarries were visited at Sodradağ, Herakleia, Euromos, and Iasos, and a few samples were obtained. Three samples were taken at the Beçin fortress and hill south of Milas, one on the plain south of Milas, and one sample removed from a particular black dressed stone at Beçin due to its resemblance to the black stone from Mount Sodra ${ }^{79}$. Some of these places are identified antique quarries, some are not. The latter are cavities in the mountains at Sodradağ and Euromos where marble has been mined, and where there are waste materials on the ground, which indicate they might have been ancient quarries. In two cases, at Beçin hill and the south plain of Milas, samples were taken from large blocks out of quarry context. There are few identified quarries around Milas and more research on this topic is of vital importance.

All sampling spots were documented and the samples studied under a magnifying glass and photographed, providing a view of the structure of the marble block as well as allowing a rough judgement of the little sample. The samples were then divided into even smaller pieces, and one half of each was sent to Florence for petrographic and mineralogical analyses ${ }^{80}$. The laboratory methods applied permit the determination of the chemical composition, the internal structures of the marbles, and show similarities and differences between the samples. Nineteen samples from structures at Labraunda were brought to Rome for additional analytic methods such as isotopic analysis, Electron Paramagnetic Resonance spectroscopy (EPR) and petrographic analysis, for the measurement of maximum grain size (MGS) and colour of the samples, and comparing the marbles in the general database in order to establish a certain or most probable provenance ${ }^{81}$.

73) Strabo 14,2.23; Aelian, on animals, XII, 30

74) See Prochaska and Grillo 2012: 584-592. On the methods see Attanasio et al. 2012: 230-237

75) See Attanasio et al. 2012: 65-87.

76) See Attanasio et al. 2011: 1-13.

77) Fant 2013.

78) Attanasio et al. 2006: 13.

79) Henry 2013a.

80) Analyses performed by Emma Cantisani. Experimental methods used: Thin sections of samples were documented by optical microscopy in transmitted light. A polarised light microscope (ZEISS Axioscope A1) equipped with a camera (resolution 5 Megapixel) and dedicated image software (AxioVision) for evaluating the microstructural parameters (i.e. minumum and maximum diameter) was used.Powders obtained from each sample were analysed with a PANalytical diffractometer X'Pert PRO with radiation CuKal= $1,545 \AA$, operating at $40 \mathrm{KV}, 30 \mathrm{~mA}$, investigated range $2 \mathrm{q} 3-70^{\circ}$, equipped with $\mathrm{X}^{\prime}$ Celerator multi-detector and High Score data acquisition and interpretation software for determining the mineralogical composition.

81) Performed by Donato Attanasio, ISM-CNR, Rome and Walter Prochaska, Institute of Archaeology, Oxford. For a complete description of the investigation methods and results see appendix. 


\section{LABRAUNDA, ITS BUILDINGS AND THE SAMPLING SPOTS}

Remains of buildings dated to the archaic or pre-Hekatomnid period have been found at Labraunda, but the main building activity at the Sanctuary took place in one of four main phases; the Hekatomnid period c. 392-330 B.C., the Hellenistic 330-27 B.C., the Roman 30 B.C.-A.D. 400, and the late antique or Byzantine period after $400^{82}$ (Fig. 6-8). Buildings representing all known phases have been selected for sampling. Hekatomnid and later structures have been identified and dated by inscriptions and by archaeological means ${ }^{83}$.

In the Hekatomnid period there was an intense building period. It has been assumed that buildings dedicated by Idrieus were later than those of Maussollos, supposing that Idrieus began his building programme at the time he succeeded his brother as satrap. Now Hellström convincingly argues that all buildings of this period were constructed as part of one extensive dynastic project and completed before the death of Artemisia in 351, or maybe already by $353^{84}$. In this context, I will refer to Hellström's later dating.

Maussollos dedicated two buildings; Andron B and the Old North Stoa which was later rebuilt in the Roman time. One sample was removed from an architrave block with the dedication of Andron B. Idrieus dedicated Andron A, the Oikoi, the Temple of Zeus, the South Propylon, the Doric House, and presumably the East Propylon as well. Small pieces of marble were obtained at elements that belonged to these buildings. Three samples were taken at Andron B; two from blocks of the broken architrave with dedication, and one at a block with characteristic eared triglyph (Fig. 9). One sample was obtained from the architrave with dedication of the Oikoi. This building was begun by Maussollos and probably completed by Idrieus before 353 B.C..$^{85}$. The Temple of Zeus represents several construction periods; it was built in the archaic period around 500 B.C. on the site of an ancient shrine ${ }^{86}$. Maussollos planned and initiated the rebuilding of the old Temple of

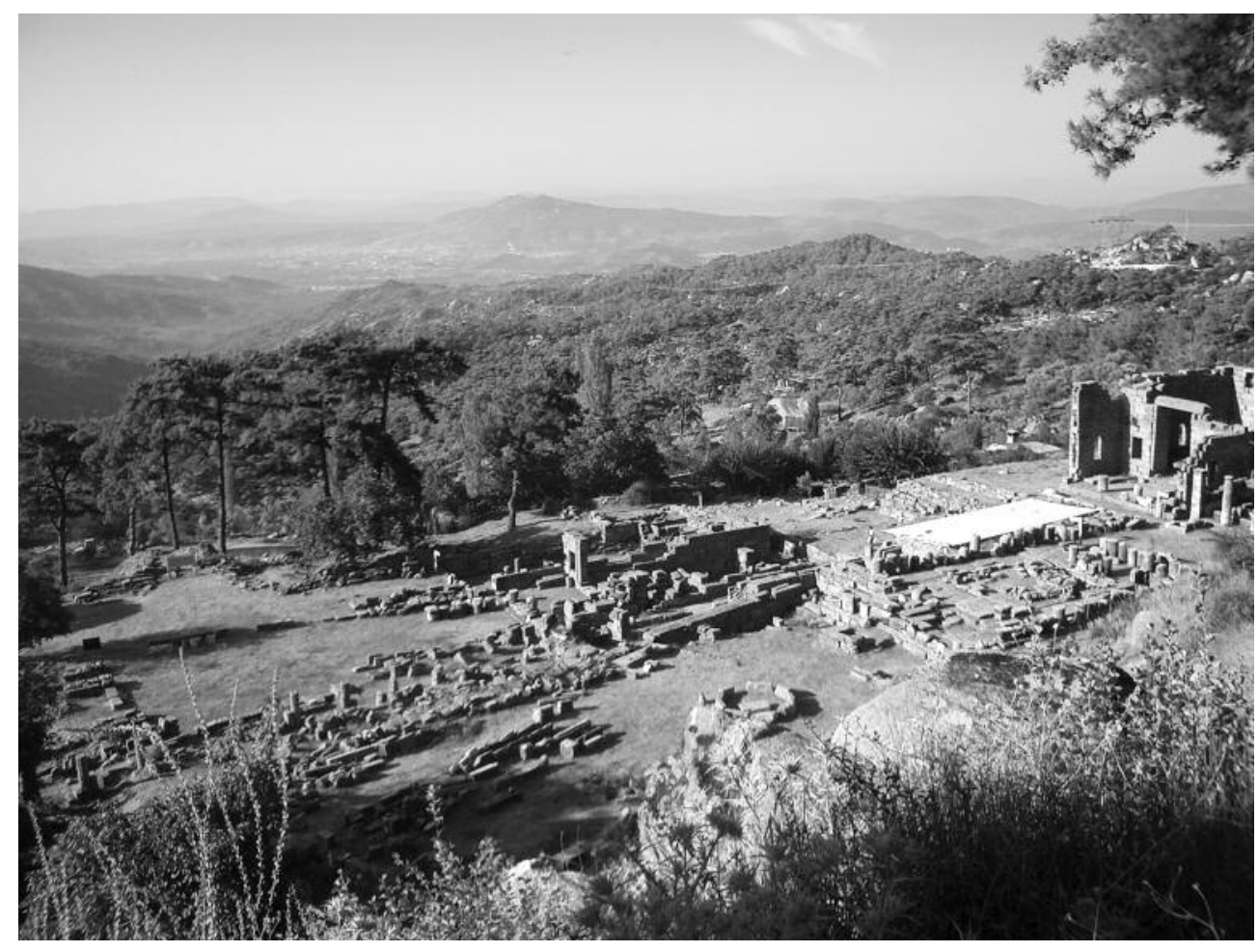

Fig. 6 : Labraunda, and the Temple terrace seen from the Split Rock (Photo A.F.).

82) Hellström 2007: 40f.

83) On the inscriptions, see Crampa 1969; 1972.

84) Hellström 2011: 154f.

85) On the inscriptions, see Crampa 1969; 1972.

86) Hellström 2015, forthcoming. 


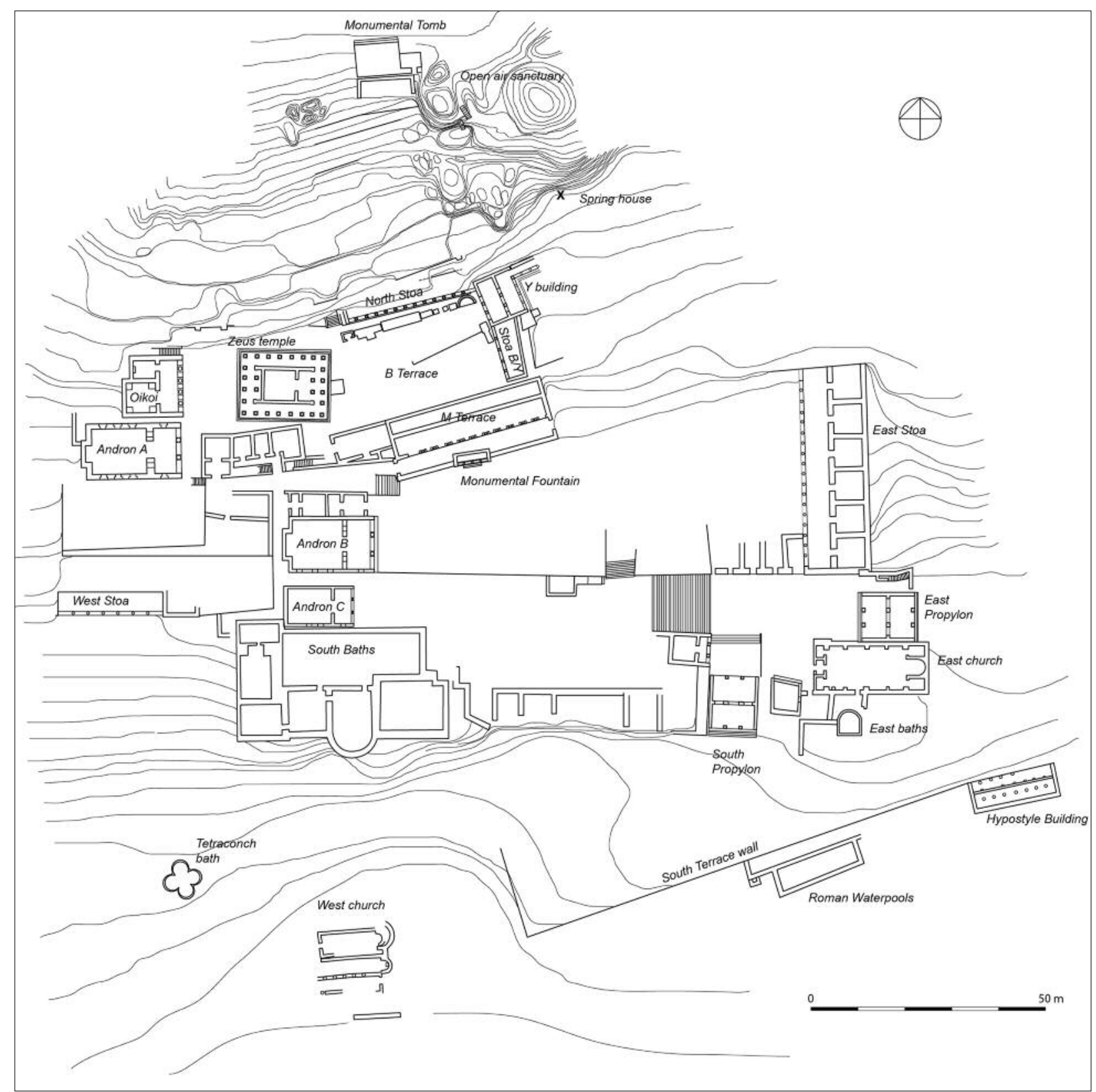

Fig. 7 : The site and its buildings (By O. Henry).

Zeus, and the former structures were incorporated into the new temple. Idrieus completed the building. One sample was obtained from an element kept in storage, which presumably belongs to the Old temple, and one sample, representing the new temple, was taken at the architrave which is part of the didactic reconstruction at the west side of the temple. Another sample was removed from the architrave with dedi- cation of the South Propylon, a building representative for the Ionic $4^{\text {th }}$ century style of Asia Minor ${ }^{87}$.

The East Propylon is presumably contemporary with the South Propylon ${ }^{88}$. One sample was removed from this architrave too. Jeppesen noted that the marble used in the building was of a bad, friable quality ${ }^{89}$. The Doric House which got its name by its Doric order may have been a treasury, a fountain

87 Jeppesen 1955: 30.

88) Karlsson 2013: 68

89) Jeppesen 1955: 6. 


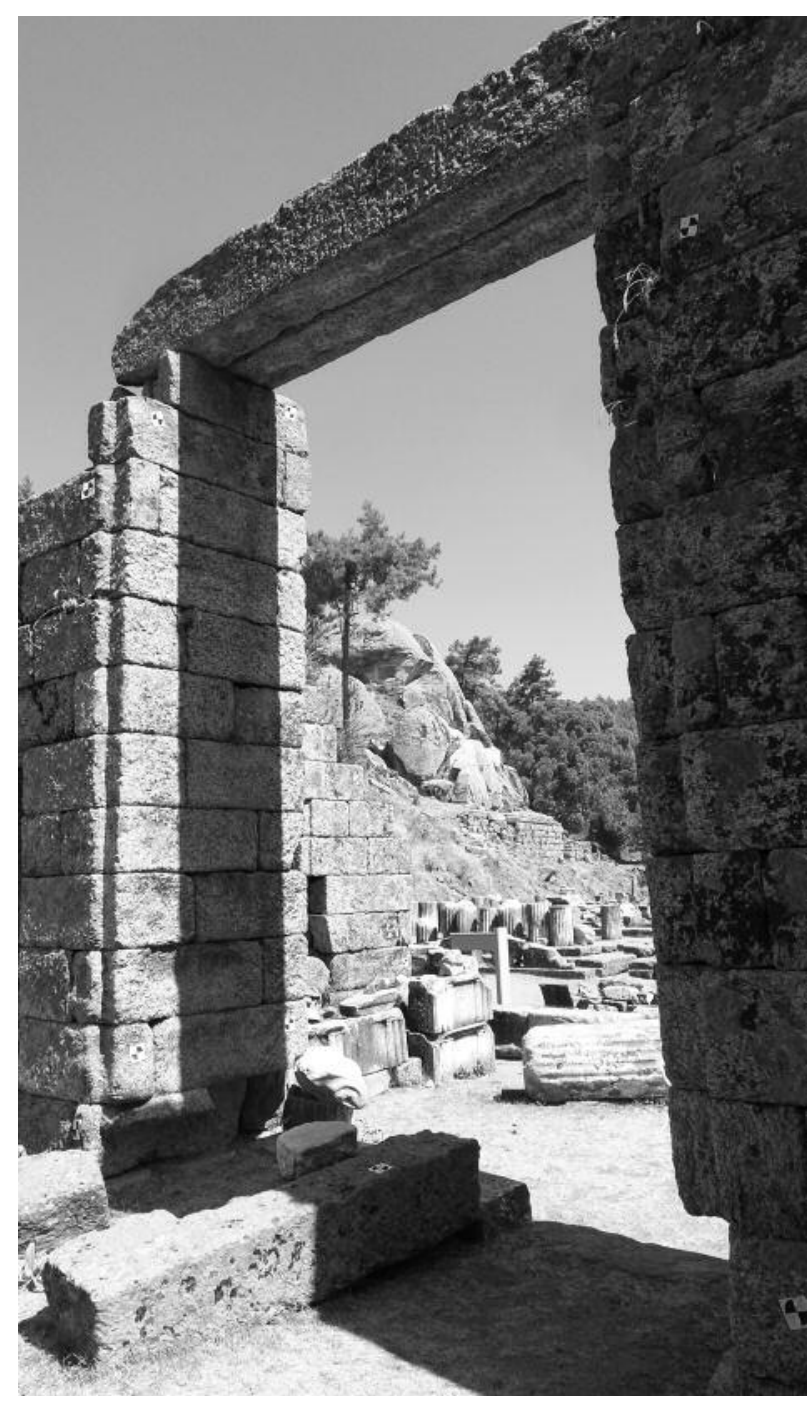

Fig. 8 : View from Andron A towards the Temple Terrace (Photo A.F.).

house or a nymphaeum. One sample was removed from the dedicatory inscription on an architrave block. The house was rebuilt in successive periods and finally it became part of the Late Antique complex of the East Church ${ }^{90}$.

The Monumental Built Tomb belongs to the Hekatomnid period too, but its foundations may be of an earlier date. The Tomb, situated roughly $30 \mathrm{~m}$ above the Sanctuary and close to the split rock, is housing three huge sarcophagi. The different dates of its construction have not been established ${ }^{91}$. A number of pieces in the Doric order have been found in the slope below the tomb ${ }^{92}$. One sample was obtained at a fragment found in the tomb's open court, and therefore assumed to have been part of the building. Yet another architectonic element that might belong to the Hekatomnid period was sampled; a fragment of a column without flutes located on the not yet excavated terrace above the entrance to the sanctuary.

There was little building activity in the Hellenistic period. One of few examples is the exedra close to the North Stoa (Fig. 10). This semicircular structure, dedicated by Demetrios Pythonos, consists of a curved back wall and a low bench ${ }^{93}$. A sample was removed from the rear side of the curved wall. Another building, Propylon $\mathrm{Y}$ at the east end of the Temple terrace, below the spring, has a long history. The building dates back to around 500 B.C. and it was rearranged many times before it was given its final form in the Roman period ${ }^{94}$. An anta block of Propylon Y, assumed to belong to the Hellenistic period, was sampled.

Many structures were rebuilt in the Roman period, among these the North Stoa which is Trajanic in its present state ${ }^{95}$. Based on the inscribed dedication of the priest Poleites, Crampa dated the building to between 102 and 114 A.D. Four samples were obtained at the North Stoa; three from Corinthian capitals, and the fourth from a block of the architrave frieze. Several architectonic elements of the Roman period are assembled at the Temple terrace. At the south part is the so-called M-terrace, with a building identified as probably a Roman basilica ${ }^{96}$. Among them are an architrave block type B and an architrave frieze type $\mathrm{C}$, both dated to the period of Trajan. A sima block, inv. B71, an un-fluted column, and an architrave block at Propylon Y, all dated to the Roman period, were sampled as well.

The last period is represented by an ambo which belonged to the West church which was built outside the sanctuary on the foundations of a stoa of the late Classical period. It was rebuilt around A.D. 400 and later, in the $5^{\text {th }}$ century it was turned into a Christian basilica $^{97}$.

90) On the Doric House and its building phases see Blid 2012: 161-220.

91) Henry 2013a: $301 \mathrm{ff}$.

92) Henry 2014.

93) Tobin 2014, 32f.

94) Hellström 2015, forthcoming.

95) Liljenstolpe and von Schmalensee 1996

96) On the structure at the Temple terrace, see Blid and Hedlund 2014, and Hedlund 2014

97) Blid 2010: 48f 


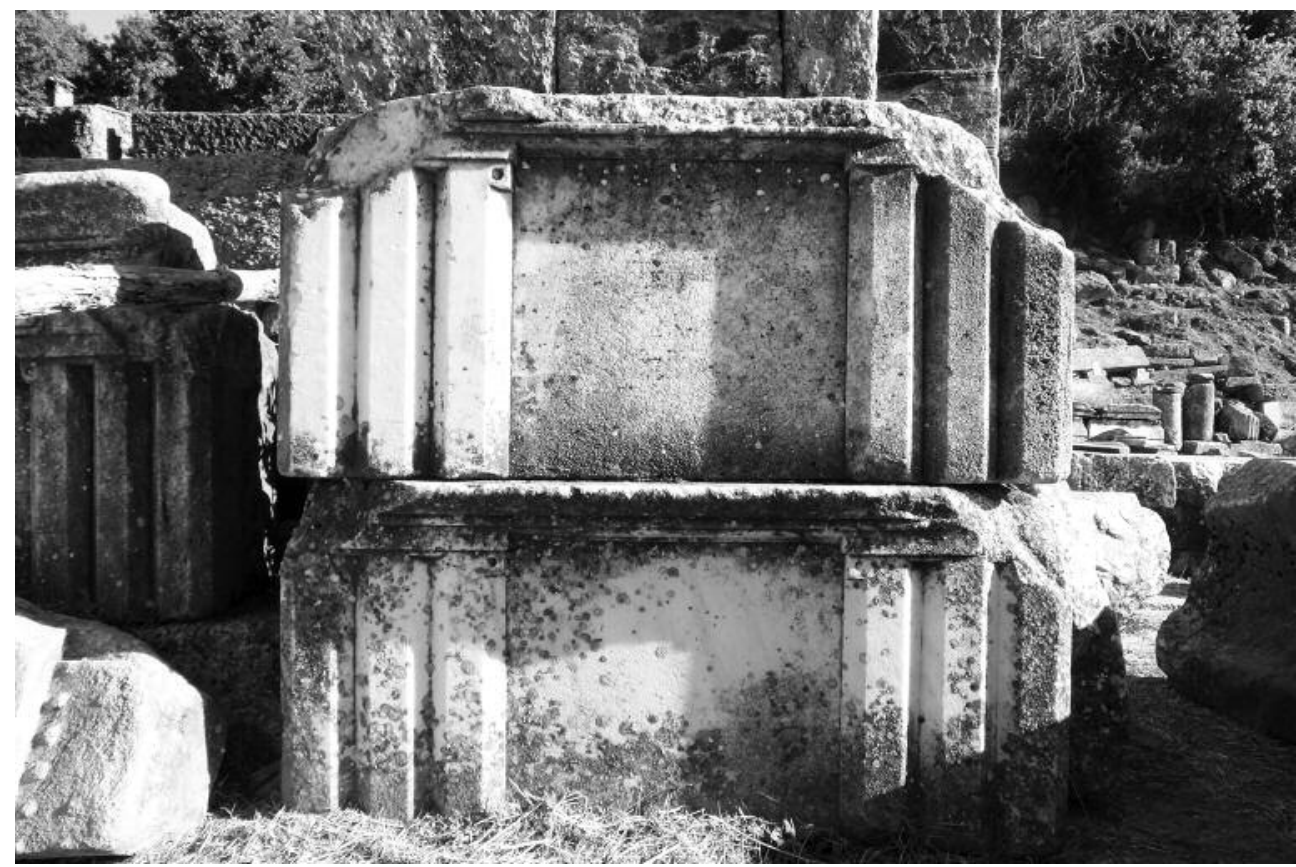

Fig. 9 : Two blocks with eared triglyphs, the upper of which was sampled (Photo A.F.).

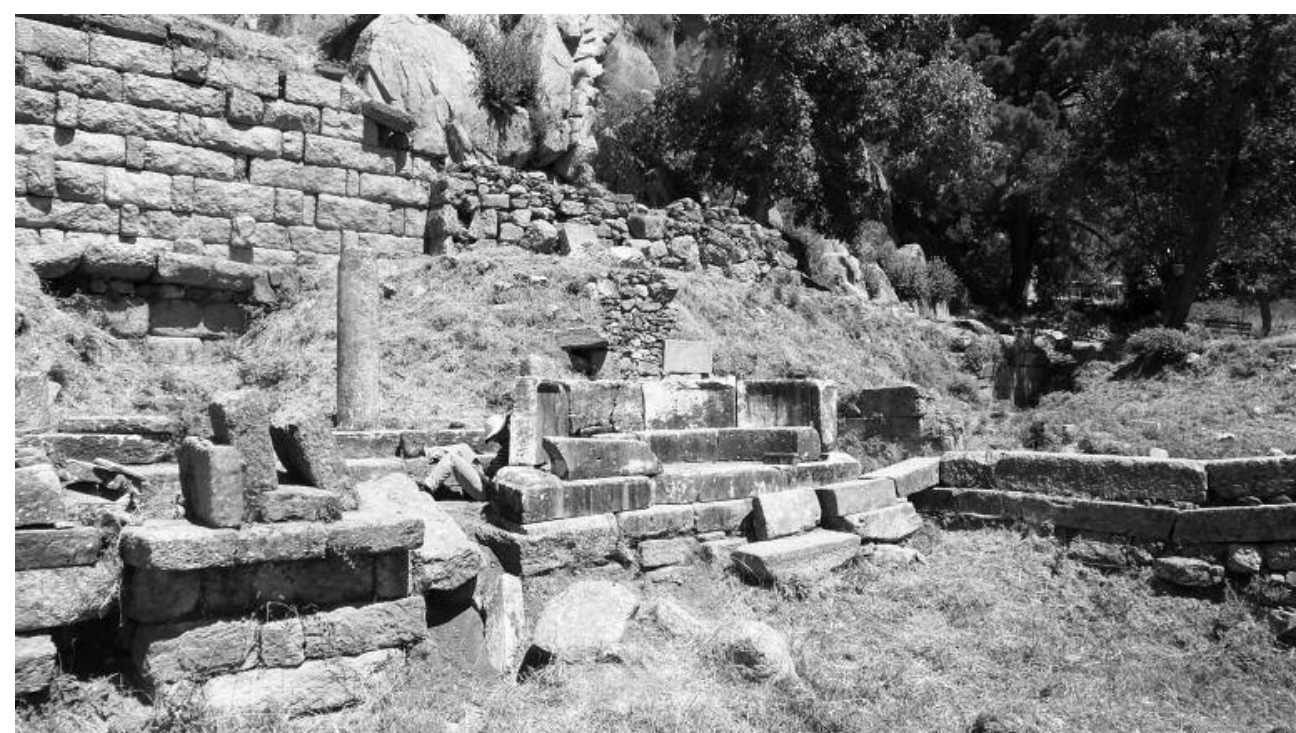

Fig. 10 : The exedra (Photo A.F.).

Building materials used at Labraunda are gneiss for the foundations and the walls. The exterior walls were then covered with a thin layer of stucco, except for the fronts which were of marble. The friezes and corniches on the Andrones were of marble too. Interior walls were, like the Mausoleum in Halikarnassos, plastered with "...stucco, so highly polished that they seem to be as glistening as glass" $"$. This description indicates that the stucco was made of a mixture of slaked lime and marble or alabaster, as was the custom in Ancient Rome and Greece ${ }^{99}$. Columns and capitals and in some cases even roof tiles on the Labraunda buildings were made of marble too. Marble had been used for sculptures and reliefs but the cult statue at the Temple of Zeus may have been of bronze ${ }^{100}$. All sculptural objects

98) Vitruvius 2.8.10.

99) Freccero $2005 ; 2008 ; 2015$, forthcoming.

100) Hellström and Thieme 1982: 32. 


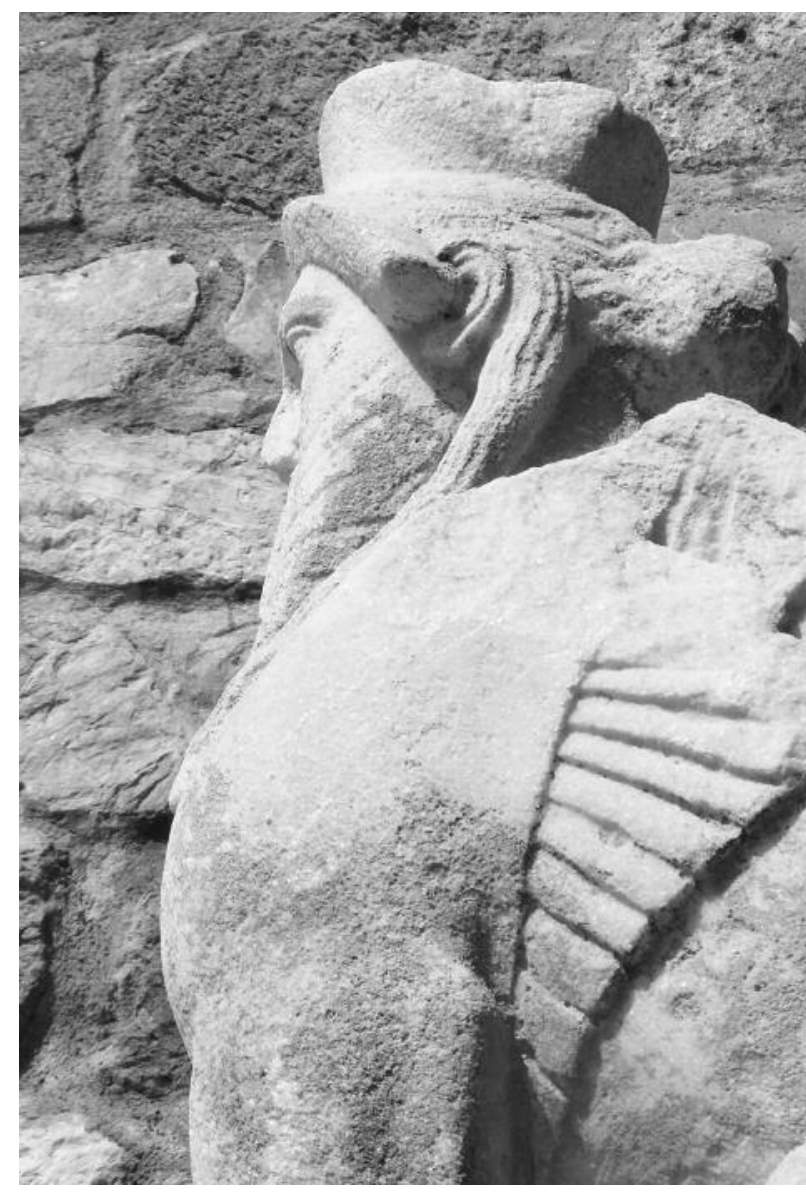

Fig. 11 : The male of white marble from Labraunda, detail (Photo A.F.).

have been removed from the site and are part of museum collections.

A sphinx, rendered as a male animal in the Oriental-Egyptian tradition, was found south of Andron $\mathrm{B}$ in $1953^{101}$. A parallel case is the two male acroteria sphinxes from the roof of the Temple of Eshmun at Sidon. The Labraunda sphinx which presumably decorated Andron B is exhibited on a high pillar in the Bodrum Museum, and other items are part of that collection too (Fig. 11). No sampling has, so far, been made on any object in museum collections.

\section{ANALYSES}

Twenty-four samples were obtained at the architectural elements mentioned above ${ }^{102}$. All samples from Labraunda received the additional letters Lab, such as LabBTomb, for the Built Tomb, in order to ascertain the Labraunda samples were kept as one group. The two first samples of white and grey marble which were removed from undated fragments are included in this investigation too, even though they are not possible to link to any specific building. Another early sample taken at a modern quarry at Stratonikeia, identified as quartz, is included as well. Two black stones are placed in the additional group of 'other stones'. I made three tables, the first of which includes all samples studied at CNR/ICVBC. The other tables show the samples investigated by all methods applied. Table 2 is focusing on the construction periods and table 3 is a concordance table.

Twenty-two samples were obtained at quarries and sites close to Labraunda. The letter Q has been added to samples obtained in quarries. Most samples were removed at Sodradağ and Beçin, two at Euromos (EQ and Euromos), four at the Herakleia/Miletos (HMQ) and three at Herakleia (HQ). One sample each was removed at the sites of Lagina and Stratonikeia. The reason for not studying additional quarry samples is the existence of a large data base created by Attanasio and Prochaska, to which Labraunda samples are compared. All samples obtained and analysed are described on schedules which are presented in alphabetic order in the appendix, at first sample from Labraunda samples and then from other quarries and sites.

Several analytical methods have been applied on the Labraunda samples. Each method has advantages and limits. Observations and documentation of the marble element at the time of sampling provided a first impression of the object as entity. It was succeeded by the unsophisticated method of studying the sample with a magnifying glass. This simple method permits necessary observations regarding the quality of the marble, its colour and grain size, which offer an idea that leads to the formation of some preliminary groups. Many marbles have veins of large crystals and, in such cases, the most representative area is sampled, not the particular. Areas with extremely large crystals are not sampled since, in those cases, the size of singular crystals is much too large. Therefore, samples are taken in the vicinity of the large crystals, in order to have the characteristics documented on photos. As an example, one monolithic column observed at Stratonikeia but not sampled, presented great variations; large grains and clusters of crystal at the base, large-medium

101) Karlsson 2013: 75ff.

102) 46 samples in total were examined under the microscope, and mineralogical and petrographic analyses were performed on 39 of these. 


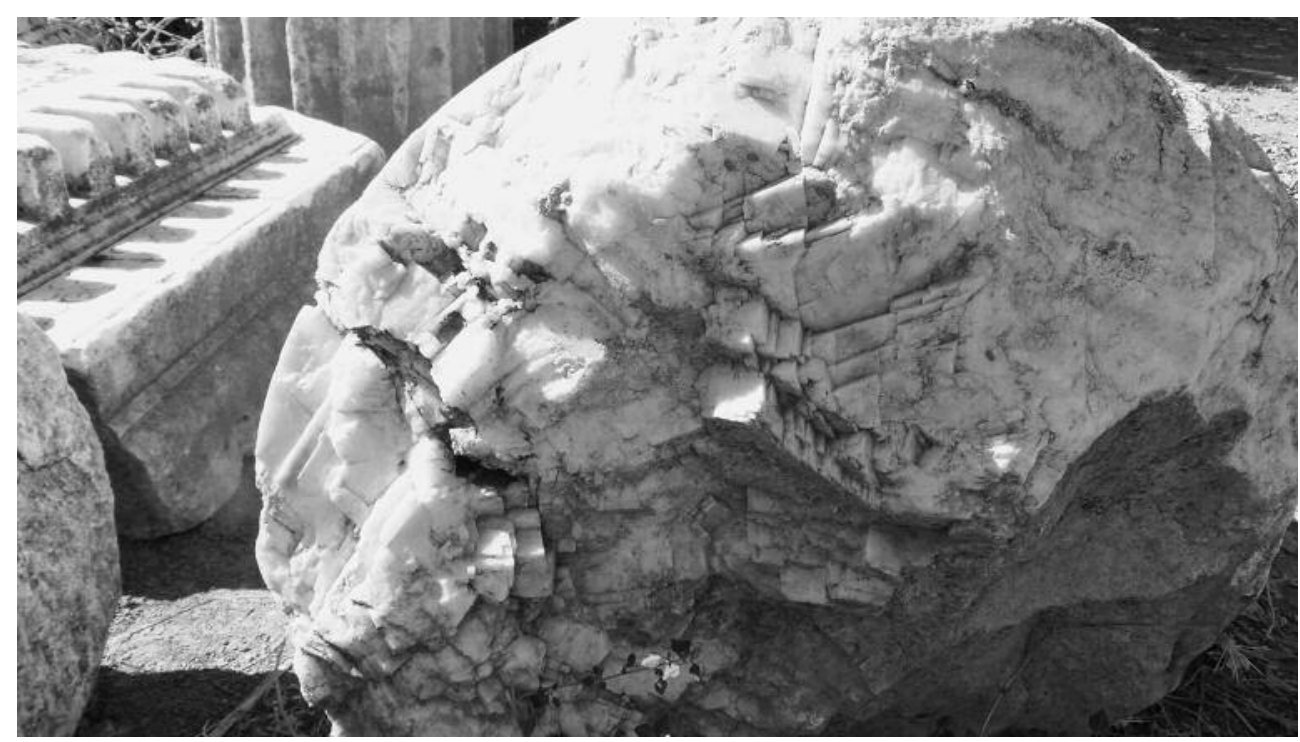

Fig. 12 : The base of the Stratonikeia column (Photo A.F.).

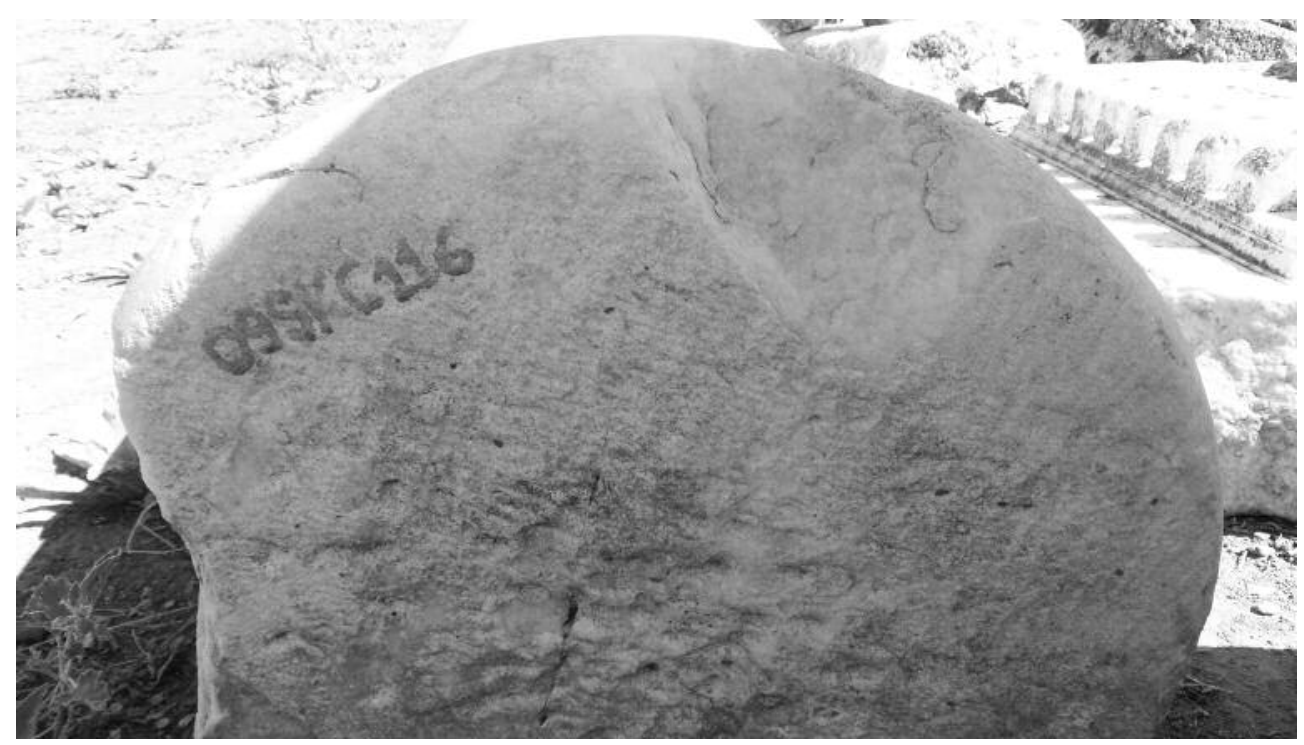

Fig. 13 : The same column, at the top side (Photo A.F.).

grains at the middle and relatively fine grains at the upper part (Fig. 12-13). If sampled, the three areas would show three different results as far as grain size is concerned. Therefore, observations of the material and documentation in situ are necessary. The disadvantage is the shortcoming in defining the type of stone, that is, the mineralogical composition, and it is impossible to determine the origin.

Mineralogical and petrographic analyses provide information about the stone investigated, if it is marble or another kind of stone. It gives information on the stone's internal structure, showing if two samples are of the same kind or not. Such analytical methods provide information about the areas sampled, not the whole object. Samples are obtained at the surface which often is weathered, not at the interior fresh stone, unless the object was recently accidentally broken. A badly decayed stone has lost much material and is not representative. Therefore, samples should preferably be large enough to comprise undamaged material. (Fig. 14-17)

Isotopic analyses constitute an additional method with which it is possible to determine the area in which the marble was once formed. Nineteen Labraunda samples were investigated by the following set of methods; isotopic analysis, Electron Paramagnetic Resonance Spectroscopy (EPR) and petrographic analysis, which was limited to measurement of max- 
imum grain size (MGS) and colour of the samples ${ }^{103}$. Based on the results and by comparisons with marbles in the general data base, it is possible to establish a statistical determination of the provenance by a linear discriminate function analysis using six

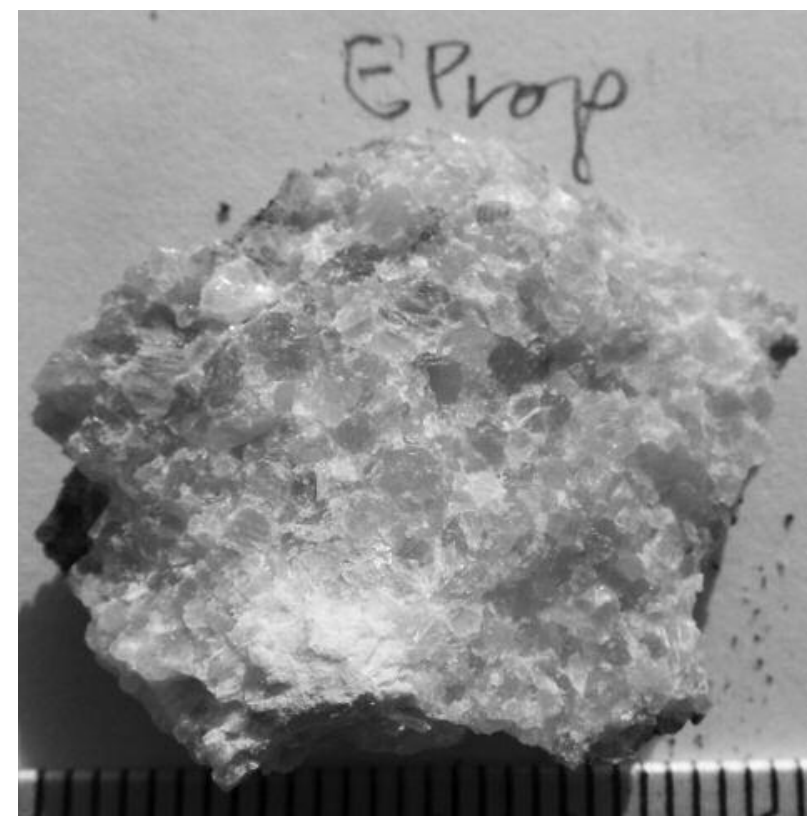

Fig. 14 : Sample LabEprop (Photo A.F.). discriminate variables, see Attanasio, Table 1 and the following figures. These are Isotopic variables $\left(\delta^{18} \mathrm{O}, \delta^{13} \mathrm{C}\right)$, EPR variables (intensity, linewidth), and petrographic/morphologic variables (MGS, colour). The statistical methods first used define suitable linear combinations, which provide the possibility of calculating the distances and probabilities of provenances.

\section{RESULTS}

Petrographic and mineralogical investigation at CNR/ICVBC confirms there are two general types of marble and these are either coarse/mediumgrained or fine-grained.

Table 1 shows the 6 groups into which all samples were placed based on results of ocular observations and petrographic and chemical analyses. Groups 1 and 2 contain large-grained white marbles. Group 3 has marbles with medium-large grains, and groups 4,5 , and 6 , contain marbles with fine grains and with different chemical compositions or structures. Group 7 contains grey marbles with dolomite composition and Groups 8 and 9 contain other kinds of stones.

Table 2 shows the samples from Labraunda on which all analytical methods were applied, and the

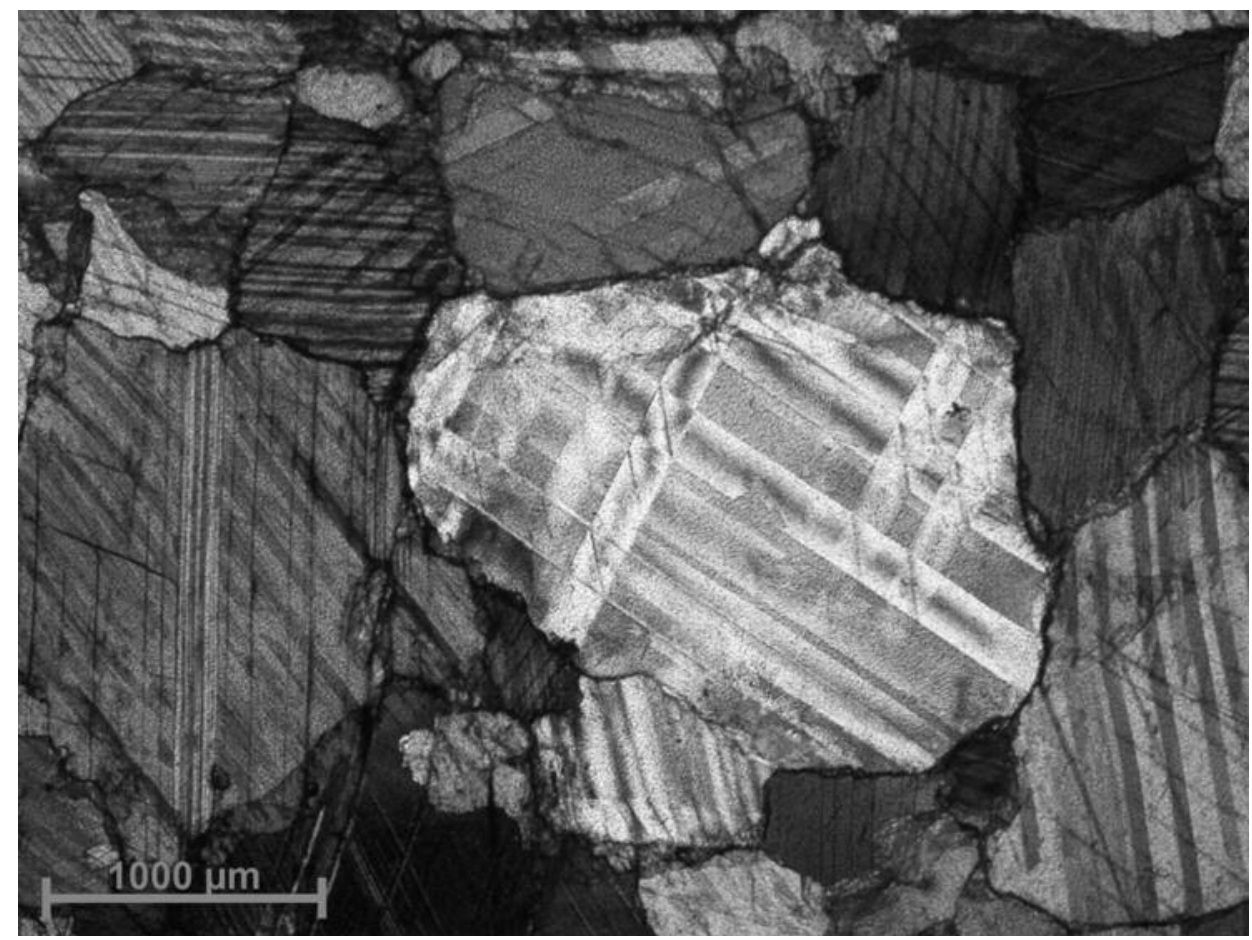

Fig. 15 : Sample EProp in polarized optical microscopy (Photo Emma Cantisani).

103) Analyses performed by Donato Attanasio and Walter Prochaska. 
periods in which the marbles were used. It shows that the marble used for Hekatomnid buildings, group 1, was brought from one quarry district, presumably Herakleia. Pure calcite marbles were used for Andron A and Andron B, but the marbles are slightly different. Further analyses will most probably provide an answer. This little difference was noted by Herz' too when he made an isotopic analysis of two samples, as explained in the schedules. These preliminary results show the marble originated from different quarries in different periods.

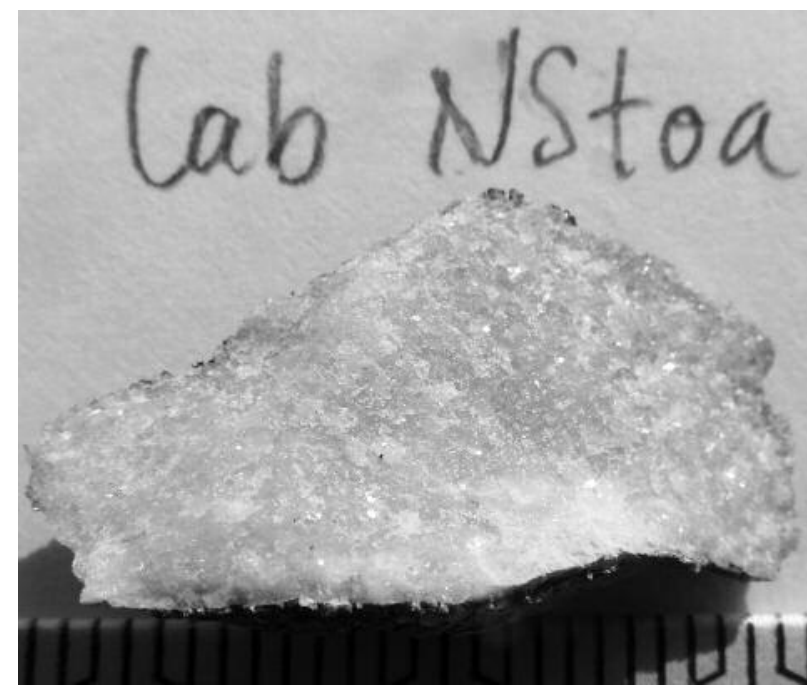

Fig. 16 : Sample LabNStoa (Photo A.F.).
The Monumental Built Tomb and the Old Temple are not dated exactly because of their complex building history - they are of the Hekatomnid period and at least partially earlier than the buildings mentioned above. The elements studied from these two buildings have a marble similar to that extracted at the Miletos quarries (HMQ), that is, the same quarries that provided marble for the Temple of Apollo at Didyma. The two architectural elements of the Exedra and the anta block of Propylon Y, dated to the Hellenistic period, have a marble of the same kind as one of the marble blocks of the podium at Beçin, which points at the possibility that the marble had been extracted in some not yet identified quarries south of Milas.

Different kinds of marble were used for the Roman elements and these marbles are spread in different groups. Most belong to group 4, where we find the Corinthian capitals, and to group 5 which contains fine-grained calcite marbles with accessory minerals and a variable microstructure. The two unfluted columns are similar in shape but the material is not. Grain sizes as well as chemical compositions differ; LabCol is of pure calcite and LabTTCol contains calcite, traces of quartz, muscovite and chlorite.

The results of isotopic analysis, electron paramagnetic resonance spectroscopy (EPR), and petrographic analysis of minimum grain size (MGS) and colour show that the 19 samples investigated belong to two main groups; course grained and fine grained.

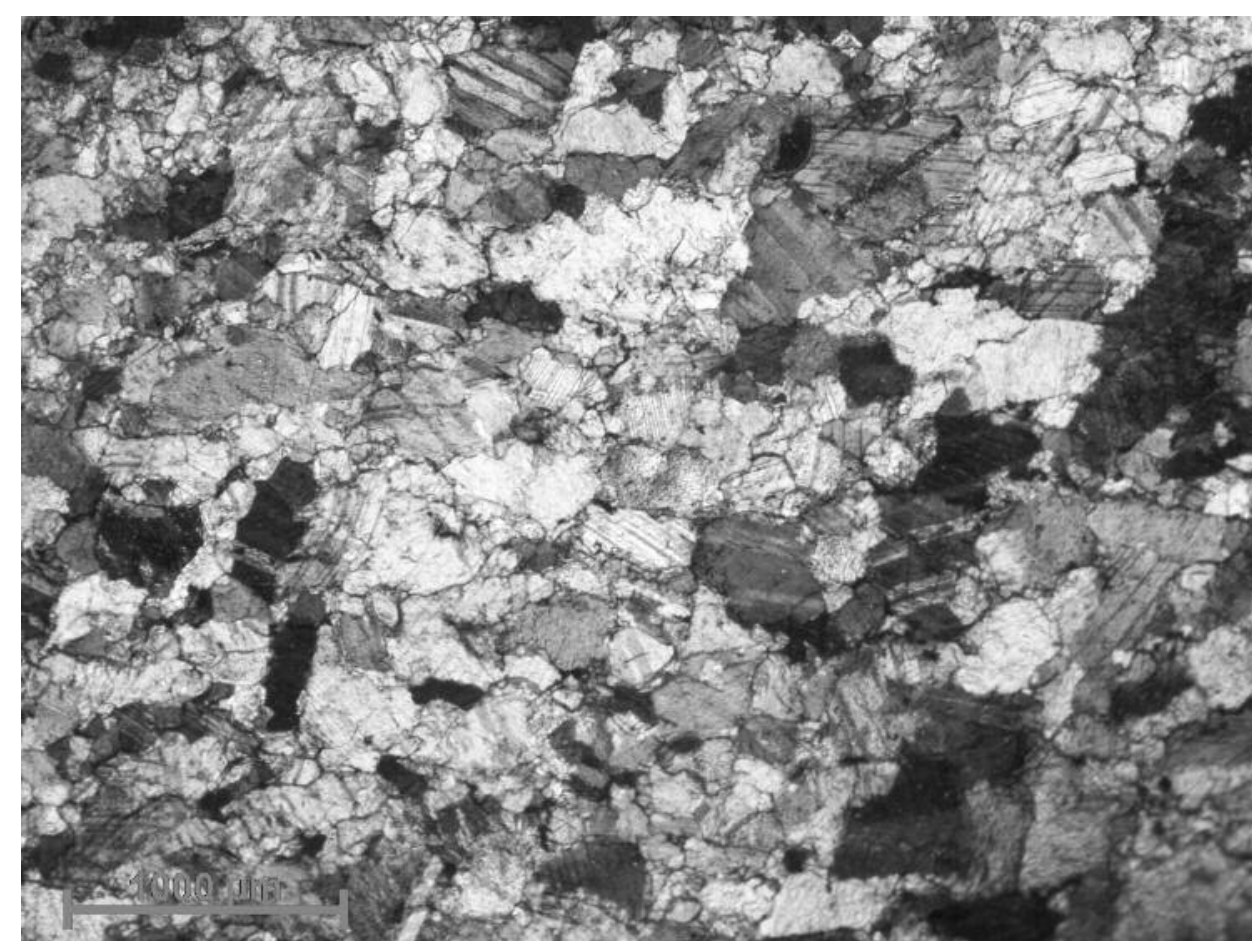

Fig. 17 : Sample LabNStoa in polarized optical microscopy (Photo Emma Cantisani). 


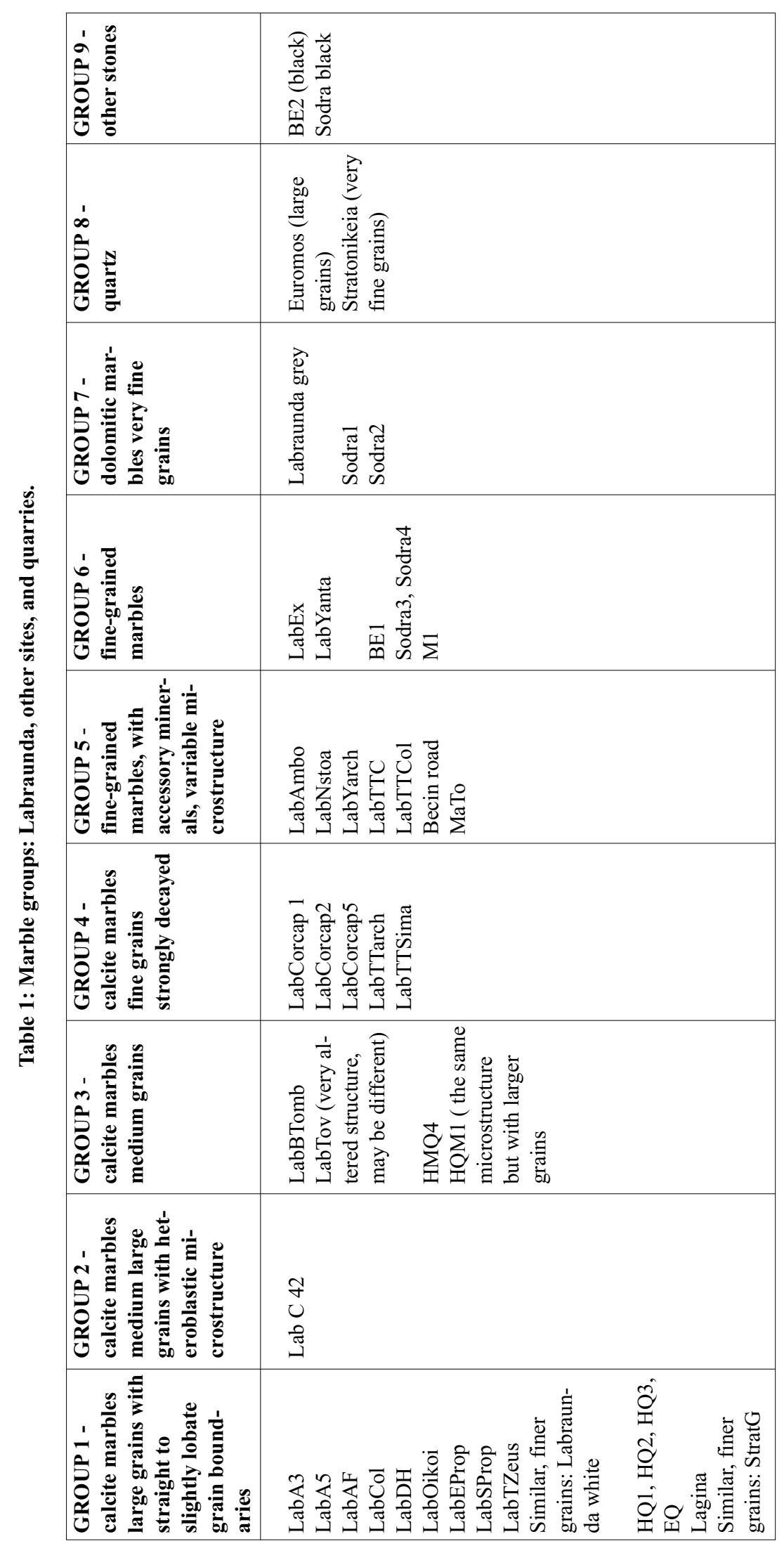


Table 2: Periods, buildings and elements, samples and marble groups.

\begin{tabular}{|c|c|c|c|c|c|}
\hline Period & Building & Architectural element & Sample & Group & $\begin{array}{l}\text { Isotopic } \\
\text { analysis }\end{array}$ \\
\hline Hekatomnid 1 & $\begin{array}{l}\text { Built Tomb } \\
\text { Old Temple }\end{array}$ & $\begin{array}{l}\text { Marble slab, inv } 3 \text { Y } 13 \\
\text { Ovolo }\end{array}$ & $\begin{array}{l}\text { LabBTomb } \\
\text { LabTov }\end{array}$ & $\begin{array}{l}\text { Group } 3 \\
\text { Group } 3\end{array}$ & $\begin{array}{l}1 \\
1\end{array}$ \\
\hline Hekatomnid 2 & $\begin{array}{l}\text { Andron B } \\
\text { Andron A } \\
\text { Andron A } \\
\text { Andron A } \\
\text { First terrace } \\
\text { Doric House } \\
\text { Oikoi } \\
\text { East Propylon } \\
\text { South Propylon } \\
\text { Temple of Zeus }\end{array}$ & $\begin{array}{l}\text { Architrave block, inv C42 } \\
\text { Architrave block, inv A3 } \\
\text { Architrave block, inv A5 } \\
\text { Eared triglyph block } \\
\text { Unfluted column } \\
\text { Architrave block } \\
\text { Architrave block } \\
\text { Architrave block } \\
\text { Architrave block, inv K81 } \\
\text { Architrave block }\end{array}$ & $\begin{array}{l}\text { Lab C42 } \\
\text { LabA3 } \\
\text { LabA5 } \\
\text { LabAF } \\
\text { LabCol } \\
\text { LabDH } \\
\text { LabOikoi } \\
\text { LabEProp } \\
\text { LabSProp } \\
\text { LabTZeus }\end{array}$ & $\begin{array}{l}\text { Group } 2 \\
\text { Group 1 } \\
\text { Group 1 } \\
\text { Group 1 } \\
\text { Group 1 } \\
\text { Group 1 } \\
\text { Group 1 } \\
\text { Group 1 } \\
\text { Group 1 } \\
\text { Group 1 }\end{array}$ & $\begin{array}{l}2 \\
- \\
2 \\
2 \\
- \\
2 \\
2 \\
2 \\
2 \\
2\end{array}$ \\
\hline Hellenistic & $\begin{array}{l}\text { Exedra } \\
\text { Propylon Y }\end{array}$ & $\begin{array}{l}\text { Central block } \\
\text { Anta block }\end{array}$ & $\begin{array}{l}\text { LabEx } \\
\text { LabYanta }\end{array}$ & $\begin{array}{l}\text { Group } 6 \\
\text { Group } 6\end{array}$ & $\begin{array}{l}1 \\
1\end{array}$ \\
\hline Roman & $\begin{array}{l}\text { North Stoa } \\
\text { North Stoa } \\
\text { North Stoa } \\
\text { North Stoa } \\
\text { Temple terrace } \\
\text { Temple terrace } \\
\text { Temple terrace } \\
\text { Temple terrace } \\
\text { Propylon Y }\end{array}$ & $\begin{array}{l}\text { Frieze/architrave } \\
\text { Corinthian capital, inv B152 } \\
\text { Corinthian capital, inv B147 } \\
\text { Corinthian capital, inv B141 } \\
\text { Unfluted column } \\
\text { Architrave, type B, inv B54 } \\
\text { Sima, inv B71 } \\
\text { Architrave/frieze type C } \\
\text { Architrave block, inv Y21 }\end{array}$ & $\begin{array}{l}\text { LabNstoa } \\
\text { CorCap1 } \\
\text { CorCap2 } \\
\text { CorCap5 } \\
\text { LabTTCol } \\
\text { LabTTArch } \\
\text { LabTTSima } \\
\text { LabTTC } \\
\text { LabYarch }\end{array}$ & $\begin{array}{l}\text { Group } 5 \\
\text { Group } 4 \\
\text { Group } 4 \\
\text { Group } 4 \\
\text { Group } 5 \\
\text { Group } 4 \\
\text { Group } 4 \\
\text { Group } 5 \\
\text { Group } 5\end{array}$ & $\begin{array}{l}1 \\
- \\
- \\
1 \\
4 \\
3 \\
3 \\
1 \\
3\end{array}$ \\
\hline Late Antiquity & West Church & Ambo & LabAmbo & Group 5 & 1 \\
\hline Undatable & $\begin{array}{l}\text { Andron A terrace } \\
\text { Andron A terrace }\end{array}$ & $\begin{array}{l}\text { Fragment } \\
\text { Fragment }\end{array}$ & $\begin{array}{l}\text { Labraunda white } \\
\text { Labraunda grey }\end{array}$ & $\begin{array}{l}\text { Group } 1 \\
\text { Group } 7\end{array}$ & $\begin{array}{l}- \\
-\end{array}$ \\
\hline
\end{tabular}


Table 3: Concordance table of historic period and marble groups determined by petrographic and mineralogical investigation (P/M) and Isotopic analyses (Iso).

\begin{tabular}{|c|c|c|c|c|c|}
\hline Period & Sample & $\begin{array}{c}\text { Architectonic } \\
\text { element }\end{array}$ & $\begin{array}{c}\text { P/M } \\
\text { Sample }\end{array}$ & $\begin{array}{c}\text { Iso. } \\
\text { Label }\end{array}$ & $\begin{array}{c}\text { Iso. } \\
\text { group }\end{array}$ \\
\hline Hekatomnid 1 & Lab Btomb & slab & 3 & AF4 & 1 \\
\hline Hekatomnid 1 & Lab Tov & ovolo & 3 & AF19 & 1 \\
\hline Hekatomnid 2 & Lab A5 & architrave & 1 & $\mathrm{AF} 1$ & 2 \\
\hline Hekatomnid 2 & Lab AF & frieze & 1 & AF2 & 2 \\
\hline Hekatomnid 2 & Lab DH & architrave & 1 & AF6 & 2 \\
\hline Hekatomnid 2 & Lab TZeus & architrave & 1 & AF11 & 2 \\
\hline Hekatomnid 2 & Lab Oikoi & architrave & 1 & AF9 & 2 \\
\hline Hekatomnid 2 & Lab Eprop & architrave & 1 & AF17 & 2 \\
\hline Hekatomnid 2 & Lab Sprop & architrave & 1 & AF18 & 2 \\
\hline Hellenistic & Lab Ex & exedra & 6 & AF7 & 1 \\
\hline Hellenistic & Lab Yanta & anta block & 6 & AF13 & 1 \\
\hline Roman & Lab TTcol & column, unfluted & 5 & AF10 & 4 \\
\hline Roman & Lab TTSima & sima & 4 & AF12 & 3 \\
\hline Roman & Lab Yarch & architrave & 5 & AF14 & 3 \\
\hline Roman & Lab TTarch & architrave/frieze & 4 & AF15 & 3 \\
\hline Roman & Lab TTC & architrave/frieze & 5 & AF16 & 1 \\
\hline Roman & Lab CorCap5 & Corinthian capital & 4 & AF5 & 1 \\
\hline Roman & Lab NStoa & architrave/frieze & 5 & AF8 & 1 \\
\hline Byzantine & Lab Ambo & ambo & 5 & AF3 & 1 \\
\hline
\end{tabular}

The samples were placed in four different groups. Below is a summary of the results in the Attanasio's report.

Group 1 includes 8 fine-grained samples exhibiting MGS values below $1.0 \mathrm{~mm}$. The properties of these samples resemble very closely the properties of the marbles from the Milas quarries located on the city's hills.

Group 2 includes 7 medium to coarse grained samples with MGS ranging from 1.1 to $3.1 \mathrm{~mm}$. These samples may belong to quarries such as Miletos, Herakleia on Lathmos or Stratonikeia. The correct provenance is based on statistical analyses of the small differences that do exist, according to which the quite reliable assignment is Herakleia.
Group 3 includes 3 fine grained samples that differ markedly from group 1 for their unusually high $\delta^{13} \mathrm{C}$ (from 5.84 to 6.53 ). This is quite unusual in the sense that no quarry data with similar value exists within the whole database. It is therefore reasonable to assume that these marbles originate from an unknown marble site in the region. Some marbles collected at Alinda presented the same characteristics, and these may all originate from the same quarry.

Group 4 contains one sample that differs from all other samples tested for its negative oxygen shift. The sample may be an Ephesian marble belonging to the Tavşantepe (so-called Farm quarry) which is the only known quarry that exhibits such negative oxygen values. See also Table 4. 
Table 4 (Attanasio): Analytical data and provenance results for the 19 samples from Labraunda together with data for the $\mathrm{X}$ quarry sites (XX marble groups) considered to be possible provenances. Quarry data are summarized by mean values and total variable ranges (min-max). The isotopic and EPR variables are given in \%o or \% with respect to specific standards (Pee Dee Belemnite for isotopes and Dolomite N368 BCS for EPR). The MGS is in mm and the color value is given in \% on an 8-bit scale where black $=0$ and white $=255$. The distance and probability parameters are given in a.u. (arbitrary units) or $\%$ and are defined on page $X$.

\begin{tabular}{|c|c|c|c|c|c|c|c|c|c|c|c|c|}
\hline Label & Description & $\begin{array}{c}\text { MGS } \\
\text { mm }\end{array}$ & $\begin{array}{c}\delta_{\% o}^{18} \mathbf{O} \\
\%\end{array}$ & $\begin{array}{c}\delta_{\% o}^{13} \mathbf{O} \\
\%\end{array}$ & $\begin{array}{c}\text { EPR } \\
\text { linewid } \\
\text { th } \\
\%\end{array}$ & $\begin{array}{c}\text { EPR } \\
\text { line- } \\
\text { width } \\
\%\end{array}$ & $\begin{array}{c}\text { Color } \\
\%\end{array}$ & Site & $\begin{array}{l}\text { Dis- } \\
\text { tance } \\
\text { a.u. }\end{array}$ & $\begin{array}{c}\text { Rel. } \\
\text { Prob. } \\
\%\end{array}$ & $\begin{array}{c}\text { Abs. } \\
\text { Prob. } \\
\%\end{array}$ & $\begin{array}{c}\text { Second } \\
\text { choice }\end{array}$ \\
\hline AF1 & Lab A5, architrave & 1.4 & -3.11 & 1.38 & 34.96 & 44.2 & 178 & Herakleia & 1.5 & 38 & 82 & Stratonikeia \\
\hline AF2 & Lab AF, frieze & 2.0 & -2.85 & 2.05 & 16.25 & 50.9 & 225 & Herakleia & 1.1 & 32 & 90 & Mileto \\
\hline AF3 & Lab Ambo, ambo & 0.65 & -3.86 & 1.35 & 5.4 & 48.4 & 193 & Milas & 8.6 & 65 & 7 & \\
\hline AF4 & Lab Btomb, slab & 0.70 & -4.33 & 1.19 & 6.6 & 45.1 & 223 & Milas & 7.9 & 72 & 10 & \\
\hline AF5 & Lab CorCap5, capital & 0.55 & -3.51 & 1.65 & 35.49 & 45.1 & 189 & Milas & 1.8 & 94 & 78 & \\
\hline AF6 & Lab DH, architrave & 1.6 & -2.78 & 1.93 & 19.50 & 54.7 & 168 & Herakleia & 1.0 & 36 & 91 & Mileto \\
\hline AF7 & Lab Ex, exedra & 0.45 & -3.57 & 2.12 & 14.28 & 44.0 & 218 & Milas & 4.8 & 97 & 31 & \\
\hline AF8 & Lab Nstoa, frieze/architr & 0.8 & -4.47 & 1.69 & 16.86 & 49.0 & 205 & Milas & 1.7 & 83 & 79 & \\
\hline AF9 & Lab Oikoi, architrave & 2.3 & -3.20 & 1.70 & 16.04 & 46.1 & 202 & Herakleia & 1.9 & 43 & 76 & Mileto \\
\hline AF10 & Lab TTcol, column & 1.1 & -8.81 & 1.29 & 135.4 & 58.4 & 189 & Eph farm & 9.1 & 98 & 6 & \\
\hline AF11 & Lab Tzeus, architrave & 3.1 & -3.06 & 2.05 & 11.42 & 48.4 & 133 & Herakleia & 4.8 & 35 & 31 & Mileto \\
\hline AF12 & Lab TTsima, sima B71 & 0.6 & -6.24 & 6.31 & 407.67 & 77.1 & 169 & Eph $1 ? ?$ & 24 & 100 & 0 & \\
\hline AF13 & Lab Yanta, anta block & 0.55 & -3.57 & 1.80 & 19.69 & 44.4 & 137 & Milas & 2.1 & 93 & 72 & \\
\hline AF14 & $\begin{array}{l}\text { Lab Yarch, architrave } \\
\text { Y21 }\end{array}$ & 0.65 & -6.10 & 6.53 & 150.94 & 61.3 & 213 & Eph $1 ? ?$ & 31 & 100 & 0 & \\
\hline AF15 & $\begin{array}{l}\text { Lab TTarch, } \\
\text { architr/frieze }\end{array}$ & 0.65 & -5.71 & 5.84 & 323.89 & 70.2 & 166 & Eph 1 ?? & 46 & 100 & 0 & \\
\hline AF16 & Lab TTC, architr/frieze & 0.75 & -3.69 & 0.99 & 55.95 & 46.3 & 188 & Milas & 3.7 & 74 & 45 & \\
\hline AF17 & Lab Eprop, architrave & 1.75 & -3.41 & 1.30 & 7.98 & 42.6 & 180 & Herakleia & 2.4 & 51 & 66 & Mileto \\
\hline AF18 & Lab Sprop, architrave & 1.75 & -2.99 & 1.60 & 14.38 & 46.9 & 166 & Herakleia & 0.4 & 45 & 98 & Mileto \\
\hline AF19 & Lab Tov, ovolo & 0.65 & -2.55 & 2.51 & 10.47 & 57.4 & 196 & Milas & 4.2 & 62 & 39 & \\
\hline $\begin{array}{l}\text { Herakleia } \\
\text { on Latmos }\end{array}$ & 51 & $\begin{array}{l}1.85 \\
1.3 ; \\
2.5\end{array}$ & $\begin{array}{c}-2.59 \\
-3.4 ; \\
-1.2\end{array}$ & $\begin{array}{c}1.74 \\
-0.1 ; \\
2.9\end{array}$ & $\begin{array}{c}22.6 \\
2.4 ; \\
123\end{array}$ & $\begin{array}{c}53.2 \\
41 ; \\
74\end{array}$ & $\begin{array}{l}179 \\
99 ; \\
230\end{array}$ & & & & & \\
\hline Milas & 40 & $\begin{array}{c}0.88 \\
0.5 ; \\
1.7\end{array}$ & $\begin{array}{c}-3.48 \\
-5.3 \\
-1.8\end{array}$ & $\begin{array}{c}1.97 \\
0.1 ; \\
2.8\end{array}$ & $\begin{array}{c}45.5 \\
2 ; \\
268\end{array}$ & $\begin{array}{c}48.7 \\
39 ; \\
61\end{array}$ & $\begin{array}{l}172 \\
34 ; \\
216\end{array}$ & & & & & \\
\hline Mileto & 56 & $\begin{array}{c}1.49 \\
1.0 ; \\
2.5\end{array}$ & $\begin{array}{c}-2.56 \\
-4.0 ; \\
-1.0\end{array}$ & $\begin{array}{c}2.05 \\
1.2 ; \\
2.6\end{array}$ & $\begin{array}{l}17.7 \\
3.3 ; \\
129 \\
\end{array}$ & $\begin{array}{c}53.2 \\
41 ; \\
71\end{array}$ & $\begin{array}{c}208 \\
164 ; \\
237\end{array}$ & & & & & \\
\hline Stratonikeia & 39 & $\begin{array}{c}1.63 \\
0.9 ; \\
2.5 \\
\end{array}$ & $\begin{array}{c}-2.88 \\
-3.8 ; \\
-0.6\end{array}$ & $\begin{array}{c}2.28 \\
1.6 ; \\
2.7\end{array}$ & $\begin{array}{l}25.0 \\
16.3 \\
49.8 \\
\end{array}$ & $\begin{array}{c}50.0 \\
34, \\
65 \\
\end{array}$ & $\begin{array}{l}190 \\
162, \\
212 \\
\end{array}$ & & & & & \\
\hline Efeso 1 & 88 & $\begin{array}{c}1.74 \\
0.4 ; \\
4.6 \\
\end{array}$ & $\begin{array}{c}-4.42 \\
-8.3 ; \\
-2.2\end{array}$ & $\begin{array}{c}3.81 \\
-0.6 ; \\
5.1\end{array}$ & $\begin{array}{c}60.0 \\
14.7- \\
513 \\
\end{array}$ & $\begin{array}{c}56.4 \\
42 ; \\
73 \\
\end{array}$ & $\begin{array}{c}191 \\
105 ; \\
231\end{array}$ & & & & & \\
\hline Efeso 2 & 38 & $\begin{array}{c}1.71 \\
1.3 \\
2.4\end{array}$ & $\begin{array}{c}-3.14 \\
-4.3 ; \\
-2.6\end{array}$ & $\begin{array}{c}0.35 \\
-0.8 ; \\
1.5 \\
\end{array}$ & $\begin{array}{c}41.8 \\
23 ; \\
69\end{array}$ & $\begin{array}{c}45.5 \\
39 ; \\
60 \\
\end{array}$ & $\begin{array}{c}194 \\
158 ; \\
221\end{array}$ & & & & & \\
\hline Efeso Farm & 14 & $\begin{array}{c}1.85 \\
1.3 ; \\
2.5\end{array}$ & $\begin{array}{c}-6.27 \\
-9.1 ; \\
-4.6\end{array}$ & $\begin{array}{c}2.04 \\
1.3 ; \\
2.4\end{array}$ & $\begin{array}{c}192.5 \\
82 ; \\
522\end{array}$ & $\begin{array}{c}59.2 \\
51 ; \\
66\end{array}$ & $\begin{array}{c}140 \\
126 ; \\
159\end{array}$ & & & & & \\
\hline $\begin{array}{l}\text { Efeso } \\
\text { Aya Klıkiri }\end{array}$ & 10 & $\begin{array}{c}2.16 \\
1.9 ; \\
2.5\end{array}$ & $\begin{array}{c}-6.20 \\
-7.1 ; \\
-5.3\end{array}$ & $\begin{array}{c}0.78 \\
-0.3 ; \\
2.3\end{array}$ & $\begin{array}{l}63.8 \\
12 ; \\
239\end{array}$ & $\begin{array}{c}50.9 \\
40 ; \\
67\end{array}$ & $\begin{array}{c}216 \\
202 ; \\
228\end{array}$ & & & & & \\
\hline Proconn 1 & 380 & $\begin{array}{c}1.72 \\
0.4 ; \\
3.5\end{array}$ & $\begin{array}{c}-2.08 \\
-5.2 ; \\
-0.3\end{array}$ & $\begin{array}{c}2.65 \\
-0.9 ; \\
3.9\end{array}$ & $\begin{array}{c}6.0 \\
0.8 ; \\
46.4\end{array}$ & $\begin{array}{c}57.8 \\
37 ; \\
87\end{array}$ & $\begin{array}{c}197 \\
137 \\
243\end{array}$ & & & & & \\
\hline
\end{tabular}




\section{CONCLUSIONS}

The methods applied to study nineteen samples of white marble from dated structures at Labraunda show that they constitute two principal groups; coarse/medium-grained and fine-grained. All facts indicate that, as a principle, the coarse/medium grained marble used during the Hekatomnid period was quarried at Herakleia on Lathmos, and that the fine grained quality used in the Roman period had been extracted at Milas.

Two samples of the Hekatomnid period fall out; both are regarded as earlier than the period of Maussollos/Idrieus, therefore labelled Hekatomnid 1. Mineralogical/petrographic analysis of these calcite marbles of medium grain size, assigned them, together with three samples from the Miletus quarries to group 3, but in the isotopic investigation they belong to the Milas marble group, which means there are some uncertainties regarding the marbles of the Old Temple and the Monumental Built Tomb. Were they extracted at Miletus or Milas? All methods consider the samples labelled Hekatomnid 2 as Herakleian marbles, and as a consequence, it can be established that the marble for the extensive Hekatomnid building programme was brought from quarries in the Herakleia district. Only two elements of Hellenistic structures were sampled. These marbles were on petrographic and mineralogical criteria placed in the fine-grained group 6 together with marbles from Beçin and the areas south of Milas. According to the isotopic investigation these samples belong to the Milas marble group too. Further studies are needed to determine the location of the actual quarry.
The marbles used in the Roman period have one characteristic in common; they are all fine-grained. However, the petrographic/mineralogical investigations as well as the isotopic investigation show there is not one kind of marble, but varieties. The variations may be explained as due to different extraction areas in Milas or other areas in the vicinity, as is the case with the unfluted column at the Temple Terrace, which by Attanasio and Prochaska is regarded as made of marble from Ephesus. Three elements had quite a different isotopic fingerprint. Samples with the same characteristics had been collected by Prochaska at Alinda and therefore these marbles presumably derive from the same, not yet identified quarry.

The questions regarding marble trade show that large and heavy blocks of marble were transported in the Hekatomnid period; in fact, transport and trade in the area had been developed at a much earlier date, both by land and by sea. The Hekatomnids as a prominent family and rulers of the region had the means to bring the marbles they preferred from near and from far away, as shown at the building programme at Halikarnassos and at the Sanctuary of Labraunda. The identification of quarries has provided evidence of trade and transport routes in the area from the Hekatomnid period to Late Antiquity. Some buildings were made of imported marble while local marble was used for other constructions. Further studies are needed in order to establish the location of some not yet identified quarries.

A. F. 


\section{ANNEXE 01 - LABRAUNDA SCHEDULES and ANALYSIS}

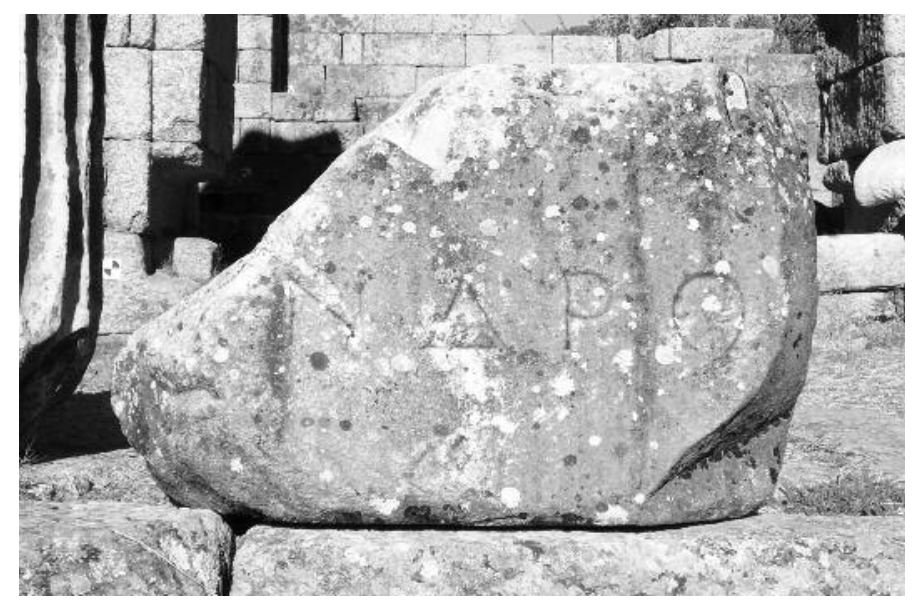

Fig. 18.

\section{Sample: Lab A3}

(Fig. 18-19)

Location: Andron A.

Object: Inscribed block, inv. A3. Architrave with dedication of Idrieus. Letters visible on this block are $\mathrm{N} \Delta \mathrm{P} \Omega$.

Period: 351-344 B.C.

Photos: SAM 8594; 9011-12.

Sampling: September 2013.

Ocular investigation: Coarse-grained white marble with grey veins.

Analyses

Herz (Isotopic analysis)

Results: Coarse-grained (1-2 mm) calcite crystals.

Isotope analysis: Heracleia (76\%), Paros (74), Aphrodisias (67). Most probably the marble came from Herakleia sul Latmos/Bafa Gölü.

CNR/ICVBC (optical microscopy, mineralogical and petrographic investigation).

Results: Marble with medium large grains.

Mineralogical composition: pure calcite.

Petrographic description: Granulometry: Maximum: $2 \mathrm{~mm}$; Medium: 600 micron; Minimum 400 micron. The shape of the crystals is euhedral and the grain boundaries are straight. The microstructure is not oriented. The calcitic crystal twinning has not deformed twins.

Preliminary results

According to Herz' analyses the architrave marbles of Andron A and Andron B are quite similar. Analyses at CNR show the marbles are similar but not identical.

Samples LabA3, LabA5, LabAF, LabCol, LabDH, LabOikoi, LabEProp, LabSProp belong to the same group. All samples were obtained at buildings constructed in the

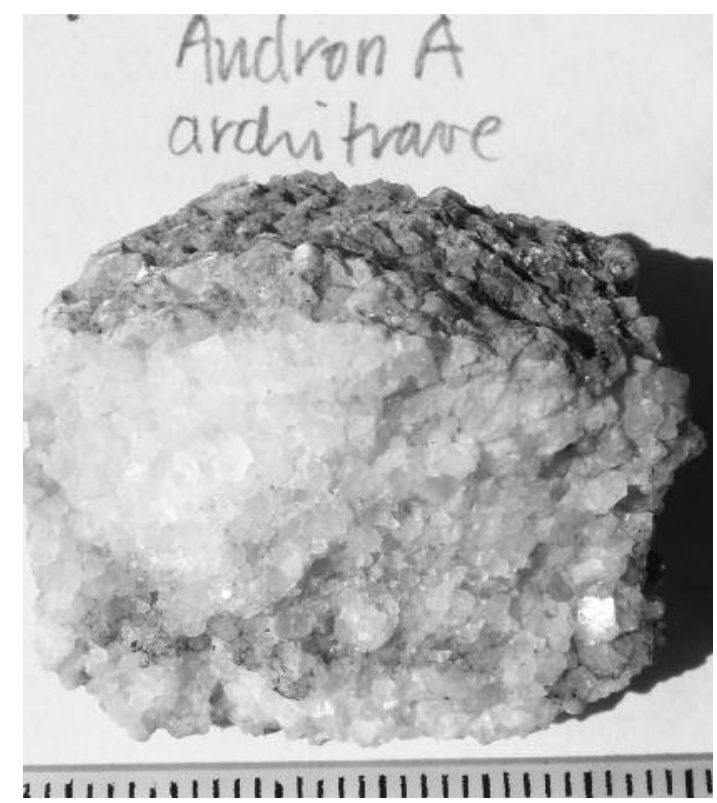

Fig. 19.

period of Idrieus, except for LabCol, for which the date is uncertain. To this group belong samples from quarries at Herakleia (HQ1, HQ2, HQ3) Euromos (EQ) and at the site of Lagina. Labraunda white is similar but with finer grains. (Group1)

\section{Notes}

Block A5 and A3 belong to central part of the broken architrave of Idrieus Andron. The marble looks, at ocular inspection, to be large-grained with areas of finer and areas of larger grains, and it looks similar to the marble used for the architrave of Maussollos Andron. This Andron was presumably built around $351 / 350$, before Idrieus became satrap and moved to Halikarnassos. The architrave was conserved in 2012.

\section{References}

Labraunda, Andron A: Crampa 1972: 11-13, pl. 1; Hellström and Thieme 1982; Hellström 2007: 127-133; 2011: 154f.

Marble: Monna and Pensabene 1977; Herz, letter to Pontus Hellström, December 11, 2006; Freccero, Conservation report 2012; Cantisani Report 2014; Freccero 2014: 51.

\section{Sample: Lab A5}

(Fig. 20-21)

\section{Location: Andron A.}

Object: Architrave with dedication of Idrieus, inv.

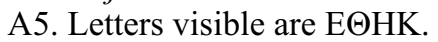




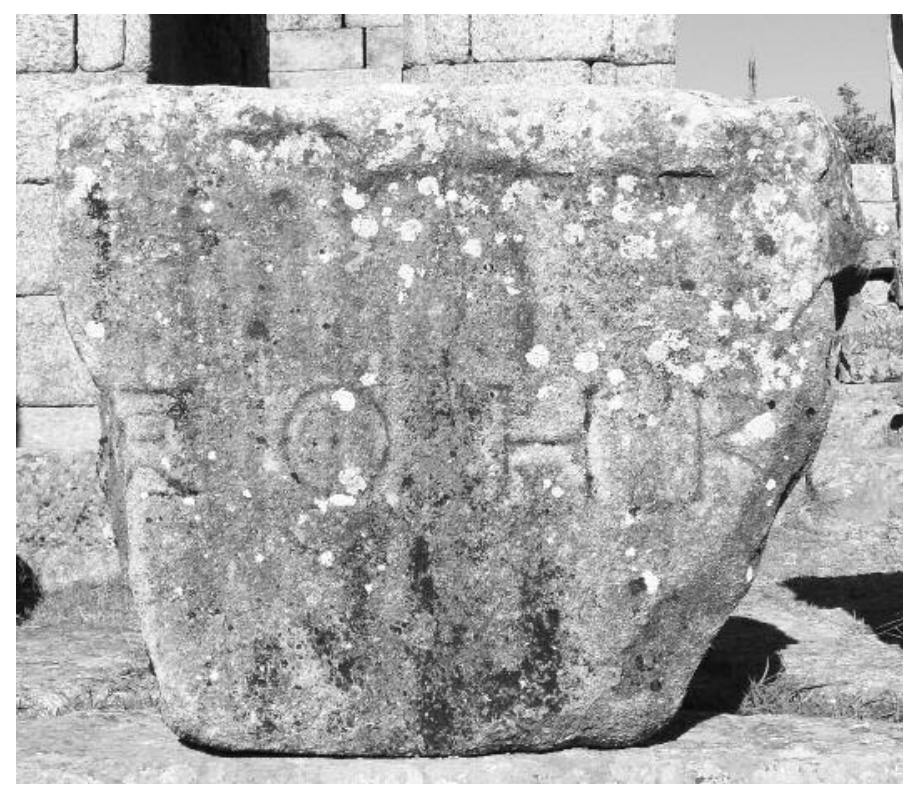

Fig. 20.

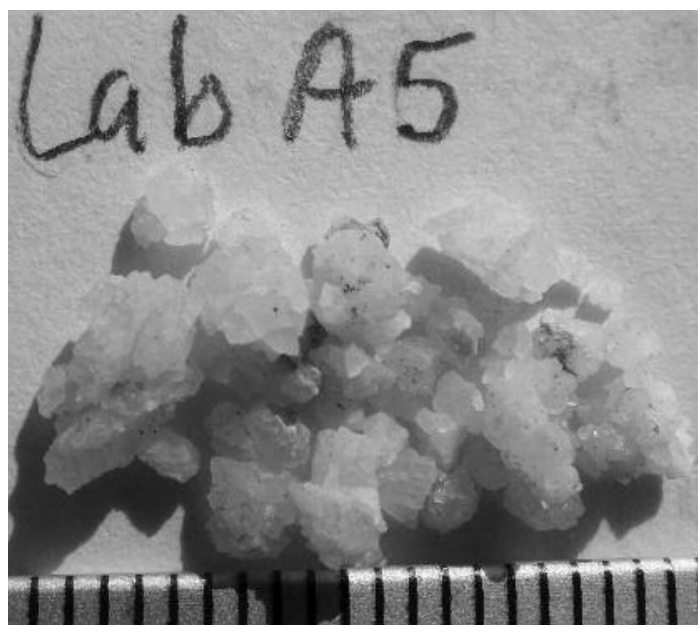

Fig. 21.
Period: Hekatomnid, Idrieus (351-344 B.C.).

Sampling: September 2013.

Photos: SAM 8592; 1271-72; 1340.

Ocular investigation: Coarse-grained white marble (1-3mm). Very frail.

Analyses

CNR/ICVBC (optical microscopy).

Results: Lab A3 and Lab A5 are very similar.

Attanasio and Prochaska (Isotopic, EPR, and petrographic analysis).

Results: marble from Herakleia (A/P: group 2, medium to coarse grained samples with MGS ranging from 1.1 to $3.1 \mathrm{~mm})$.

Preliminary results

Marbles of samples LabA3, LabA5, LabAF, LabCol, LabDH, LabOikoi, LabEProp, LabSProp belong to the same group. All samples were obtained at building constructed in the period of Idrieus, except for LabCol, for which the date is uncertain. To this group belong samples from quarries at Herakleia (HQ1, HQ2, HQ3) Euromos (EQ) and at the site of Lagina. Labraunda white is similar but with finer grains (Group 1).

\section{Notes}

Inventories A 3 and A5 are part of the same architrave and block number A5 belonged to the central part of the architrave. As the two samples were of the same kind, I decided not to do any further investigation on this sample. It is highly unlikely there would be any difference. The architrave was conserved in 2012.

\section{References}

Labraunda, Andron A: Crampa 1972; Hellström and Thieme 1981: 72, fig. 22; Hellström 2007: 127-133; Marble: Monna and Pensabene 1977; Freccero, Conservation Report 2012; Attanasio and Prochaska, Analysis 2014; Cantisani Report 2014.

\section{Sample: Lab AF.}

(Fig. 22-23)

Location: At Andron A.

Object: Triglyph block with eared triglyph, inv. Ak10.

Period: Hekatomnid, Idrieus (351-344 B.C.).

Sampling: September 2013

Photos: SAM 1272, 1293-95; 1339.

Ocular investigation: Coarse-grained white marble (1-2mm). Hard.

\section{Analyses}

CNR/ICVBC (optical microscopy)

Results: Lab AF and Lab A3 are very similar.

Attanasio and Prochaska (Isotopic, EPR, and petrographic analysis).

Results: marble from Herakleia (A/P: group 2, medium to coarse grained samples with MGS ranging from 1.1 to $3.1 \mathrm{~mm})$.

\section{Preliminary results}

Marbles of samples LabA3, LabA5, LabAF, LabCol, LabDH, LabOikoi, LabEProp, LabSProp belong to the same group. All samples were obtained at building constructed in the period of Idrieus, except for LabCol, for which the date is uncertain. To this group belong samples 


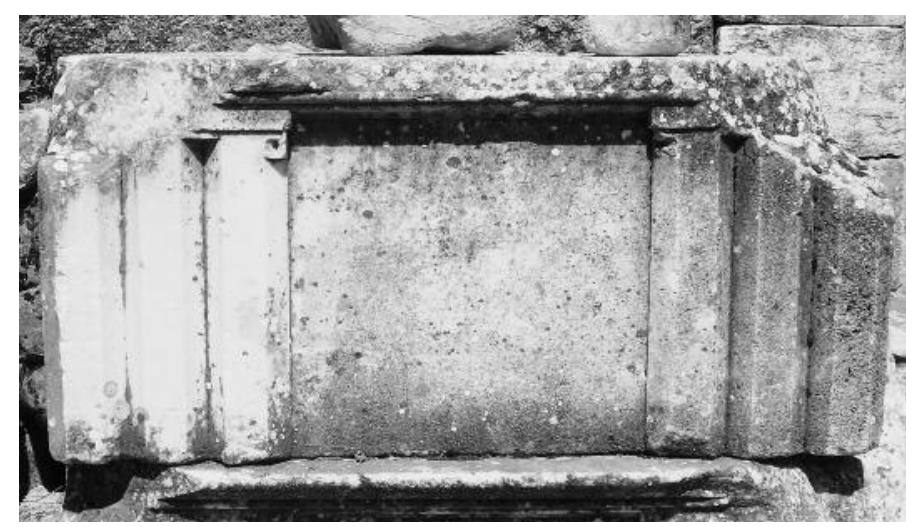

Fig. 22.

from quarries at Herakleia (HQ1, HQ2, HQ3) Euromos (EQ) and at the site of Lagina. Labraunda white is similar but with finer grains (Group 1).

\section{Notes}

The marble of this sample is of the same kind as the architrave of Andron A. It belonged to the same building, and at ocular observations under the microscope there were no indications that pointed at different marble types. Therefore the sample was not further investigated.

\section{References}

Labraunda, Andron A: Hellström and Thieme 1981: 73, fig. 25; Hellström 2007: 127-133;

Marble: Monna and Pensabene 1977; Attanasio and Prochaska, Analysis 2014; Cantisani Report 2014.

\section{Sample: LabAmbo}

(Fig. 24-25)

Location: West Church.

Object: Ambo, inv. Z07-2.

Period: $5^{\text {th }}-6^{\text {th }}$ century. Byzantine.

Sampling: September 2013.

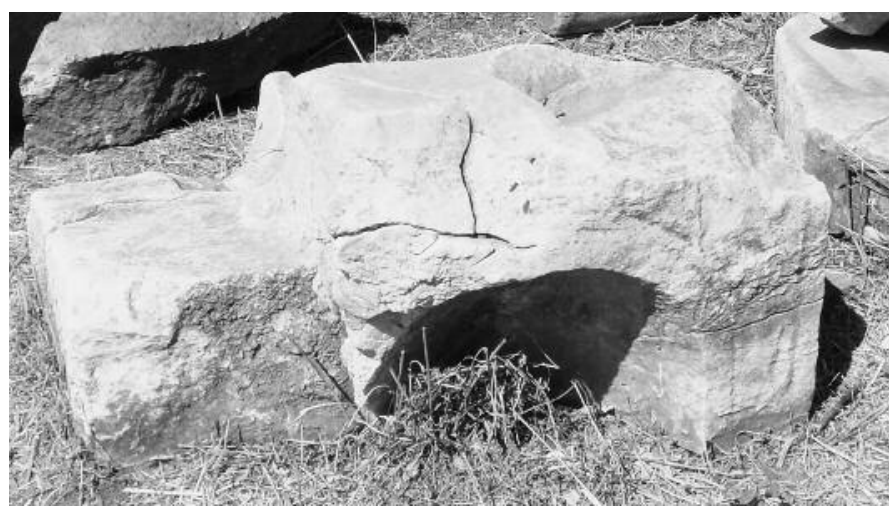

Fig. 24.

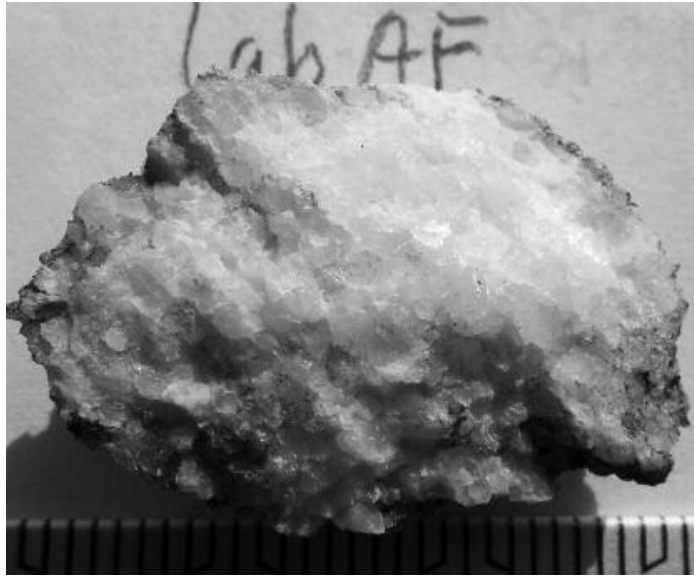

Fig. 23.

Photos: SAM 1269-70; 1325.

Ocular investigation: Fine-grained white marble. Hard.

Analyses

CNR/ICVBC (optical microscopy, mineralogical and petrographic investigation).

Results: Medium-fine marble with zones of finer grains.

Mineralogical composition: Calcite, traces of quartz.

Petrographic description: Granulometry: maximum $1 \mathrm{~mm}$, minimum 100 micron.

The prevailing crystal form is subhedral, and the boundaries between crystals are mainly lobate. The marble is strongly decayed and therefore the petrographic characteristics are difficult to discern.

Attanasio and Prochaska (Isotopic, EPR, and petrographic analysis).

Results: marble from Milas (A/P: group 1, fine grained samples with MGS below $1.0 \mathrm{~mm}$ ).

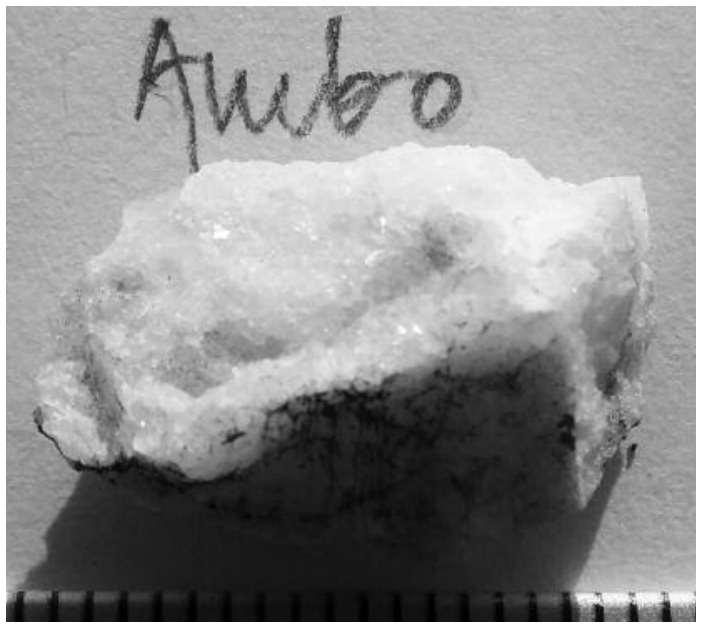

Fig. 25. 


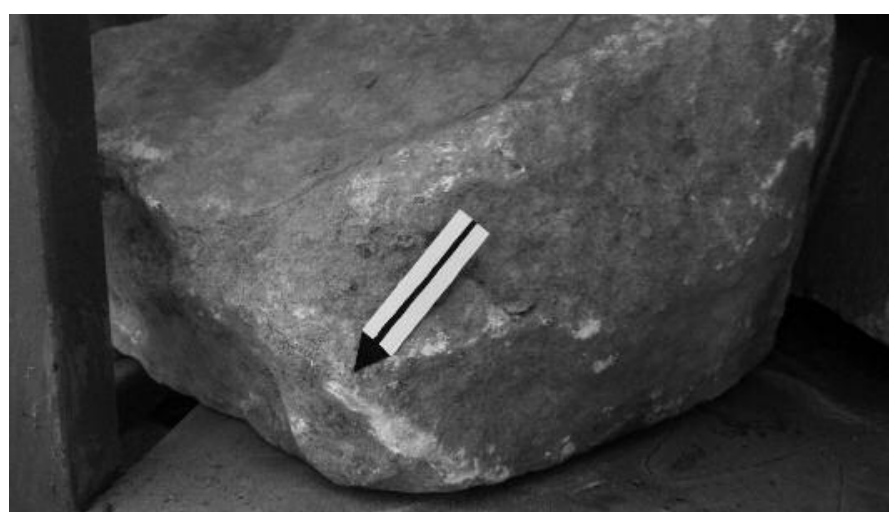

Fig. 26.

Preliminary results

This sample is placed in a group of calcite marbles with accessory minerals and variable microstructure. (Group 5)

Notes

According to Blid the ambo is typical for Karia and southern Ionia. A similar ambo found at Miletos is dated to the Late Antiquity, late $5^{\text {th }}-$ early $6^{\text {th }}$ century A.D. and another, dated to A.D. 430 was found at the Episcopal Complex at Kourion on Cyprus. The first fragments of the Labraunda ambo were found during excavations in 2007. The question was if this was a reused block or if it had been brought to Labraunda for this specific purpose.

\section{References}

Labraunda, West Church: Blid 2007: 231-255; 2010: 30-51; 2012: 136f.

Marble: Attanasio and Prochaska, Analysis 2014; Cantisani Report 2014.

\section{Sample: LabBtomb}

(Fig. 26-27)

Location: Found in the open court at the Monumental Built Tomb above the temple terrace. Depot.

Object: Marble slab. Inv. 3Y13

Period: Probably $4^{\text {th }}$ century B.C.

Sampling: September 2013.

Photos: SAM 1301-04; 1323. Hard.

Ocular investigation: Very fine-grained white marble.

Analyses

CNR/ICVBC (optical microscopy, mineralogical and petrographic investigation).

Results: Marble with fine grains.

Mineralogical composition: calcite. No visible presence of accessory minerals.

Petrographic description: Granulometry: Maximum: 350 micron, minimum: 150 micron. The crystals, of eu-

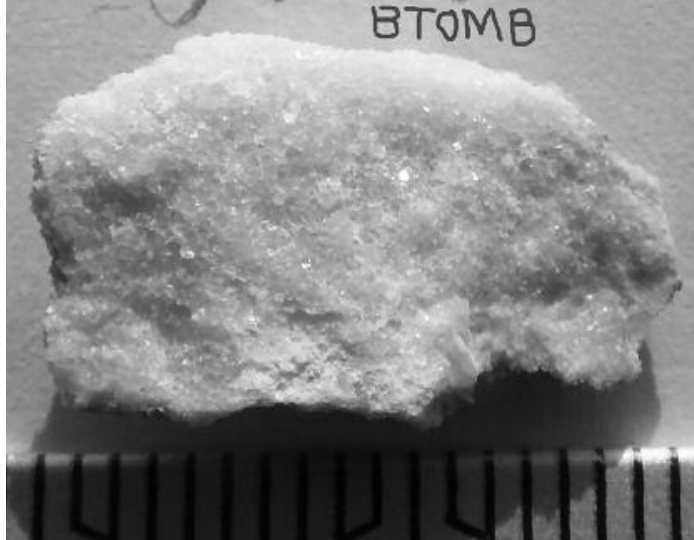

Fig. 27.

hedral form, are not oriented in any preferential way. The prevailing boundaries between crystals are straight to slightly lobate. The microstructure is slightly oriented.

Attanasio and Prochasca (Isotopic, EPR, and petrographic analysis).

Results: marble from Milas (A/P: group 1, fine grained samples with MGS below $1.0 \mathrm{~mm})$.

Preliminary results

To this group belong samples LabBtomb, and possibly LabTov, which is very altered and therefore might be different. Samples from Miletos quarries (HMQ1, HMQ3, and HMQ4) belong to this group too (Group 3).

\section{Notes}

The date of the Built Tomb is not quite clear. According to Olivier Henry it resembles other monumental tombs such as the Mausoleum at Halikarnassos and the recently discovered Uzun Yuva at Milas. It is dated to the Hekatomnid period, maybe to the period of Idrieus.

\section{References}

Labraunda, Built Tomb: Hellström 2007: 135f; Henry 2011, 2012.

Marble: Attanasio and Prochaska, Analysis 2014; Cantisani, Report 2014.

\section{Sample: Lab C42.}

(Fig. 28-29)

\section{Location: Andron B}

Object: Inscribed block, inv. C 42. Architrave dedication of Maussollos. This is the final part at the right hand side of the architrave seen from the front.

Letters visible on this block are $\Omega I$ at the left hand side.

Period: 377-352 B.C.

Sampling: September 2012

Photos: SAM 8919; 9032. 


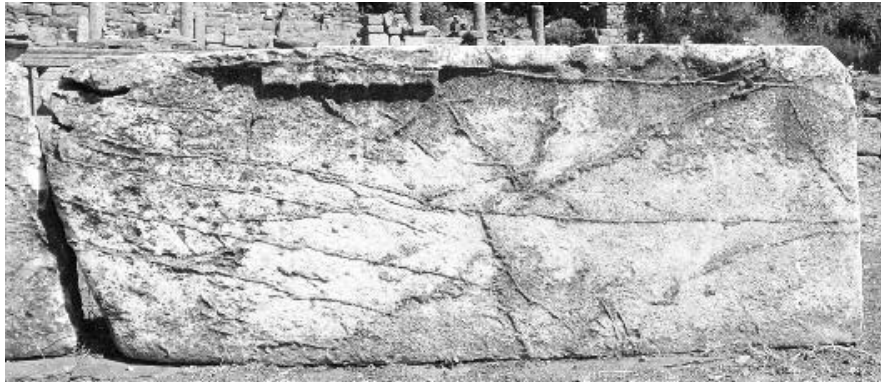

Fig. 28.

Ocular investigation: Medium-grained white marble with grey veins.

Analyses

Herz (isotopic analysis)

Results: Coarse-grained (1-2 mm) calcite crystals. Isotope analysis: Heracleia (89\%), Paros (77), Mylasa (73). Most probably the marble came from Herakleia sul Lathmos/Bafa Gölü.

CNR/ICVBC (optical microscopy, mineralogical and petrographic investigation).

Results: Marble with large sized grains.

Mineralogical composition: calcite.

Petrographic description: Granulometry: Maximum: 3 mm; Medium: 700 micron; Minimum 250 micron.

The crystals have euhedral to subhedral shape. The grain boundaries vary from straight to slightly lobate. There are zones of finer or larger grains. The microstructure is not oriented. The calcitic crystals have not deformed twins.

Preliminary results

This marble is the only of its kind obtained at Labraunda. (Group 2)

Notes

At ocular inspection the marble of the inscribed block looks partially fine-grained, but there are areas of larger grains. It looks similar to the marble used for the architrave at Idrieus Andron. Herz' analyses show the marbles are similar. According to the CNR analysis the marbles of the two Andron's are quite similar but not identical. Further studies are needed to establish the provenance. This Andron was, according to Hellström 2011: 154f, probably built around 377-6. The architrave was conserved in 2012.

\section{References}

Labraunda, Andron B: Crampa 1972: 9-11, pl. 2; Hellström and Thieme 1981: 59ff, fig. 8; Hellström 2007: 85-89; 2011.

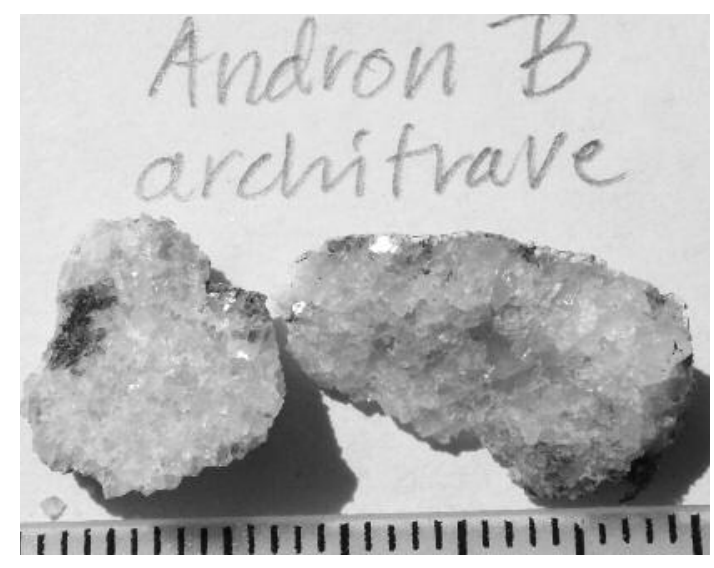

Fig. 29.

Marble: Monna and Pensabene 1977; Herz, letter to Pontus Hellström, December 11, 2006; Freccero, Conservation report 2012; Cantisani Report 2014; Freccero 2014: 51 .

\section{Sample: LabCol.}

(Fig. 30-31)

Location: The terrace above the entrance to the sanctuary.

Object: Column without flutes, without inv. nr.

Period: Presumably Hekatomnid.

Sampling: September 2012

Photos: SAM 8996, 8999, 9000; 9018.

Ocular investigation: Coarse-grained white marble.

Analyses

CNR/ICVBC (optical microscopy, mineralogical and petrographic investigation).

Results: Marble with medium-large grains.

Mineralogical composition: calcite.

Petrographic description: Granulometry: Maximum: $1.5 \mathrm{~mm}$; Medium: 700 micron; Minimum:

The crystals are of euhedral shape. The prevailing grain boundaries are straight and the microstructure is not oriented. The marble is strongly decayed, and has a high porosity due to the detachment of crystals.

\section{Preliminary results}

Samples LabA3, LabA5, LabAF, LabCol, LabDH, LabOikoi, LabEProp, LabSProp belong to the same group. All samples were obtained at buildings constructed in the period of Idrieus, except for LabCol, for which the date is uncertain. To this group belong samples from quarries at Herakleia (HQ1, HQ2, HQ3) Euromos (EQ) and at the site of Lagina. Labraunda bianco is similar but with finer grains (Group 1).

Notes

At sampling, the question was if this column was of the Hekatomnid or the Roman period. It is located in an 


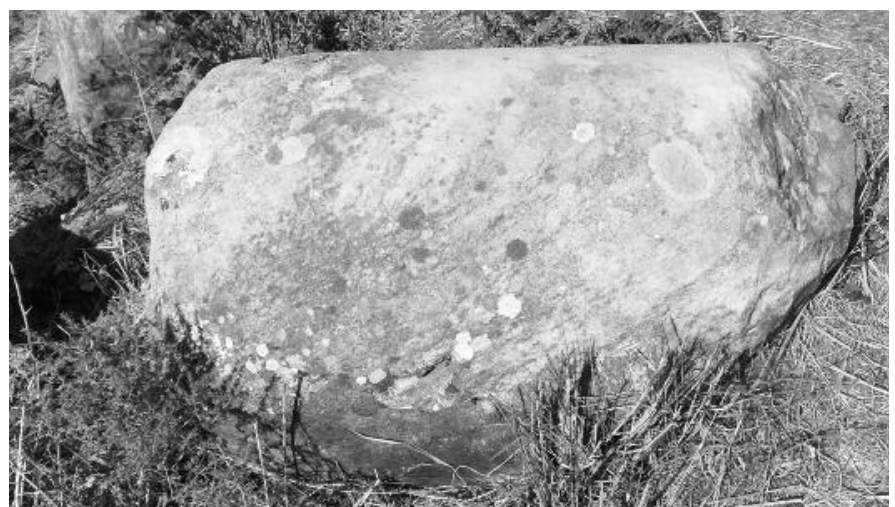

Fig. 30.

area, by Westman called space 28, which has not yet been excavated. At ocular inspection the marble of the column looks similar to the marble used for the two architrave blocks of the andrones of Maussollos and Idrieus. According to the CNR analysis the marbles are quite similar but not identical.

\section{References}

Marble: Cantisani Report 2014; Freccero 2014: 51.

\section{Sample: Lab CorCap 1}

(Fig. 32-33)

Location: North Stoa

Object: Corinthian capital, inv. B152. janus).

Period: Roman period, Poleites A.D. 102-114 (Tra-

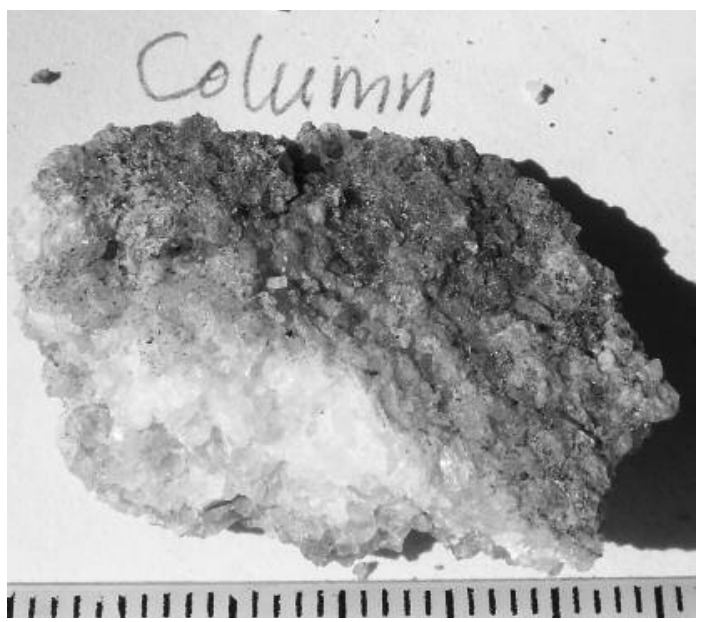

Fig. 31 .

Sample: Lab CorCap 1

Sampling: September 2012.

Photos: SAM 1103-04; 9005.

Ocular investigation: Fine-grained white marble.

Analyses

CNR/ICVBC (optical microscopy, mineralogical and petrographic investigation).

Results: Marble with very fine grains.

Mineralogical composition: calcite.

Petrographic description: Granulometry: Maximum: 600 micron; Medium: 200 micron; Minimum: $50 \mathrm{mi}-$ cron.

The crystals have subhedral shape. The grain boundaries vary from straight to lobate. This sample is characterized by areas that are strongly deformed, and presents phenomena of alteration.

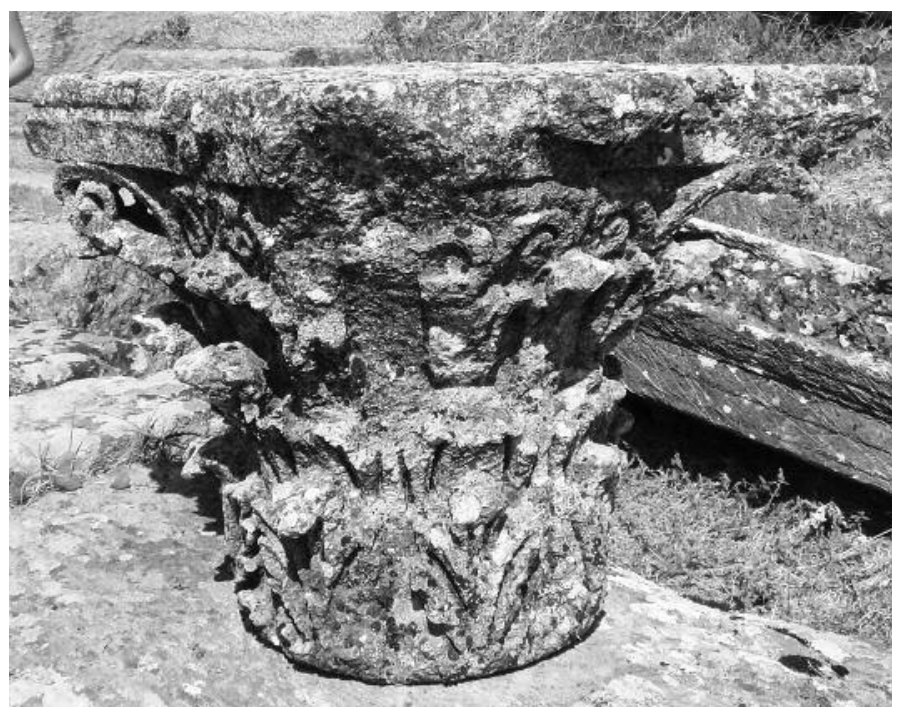

Fig. 32.

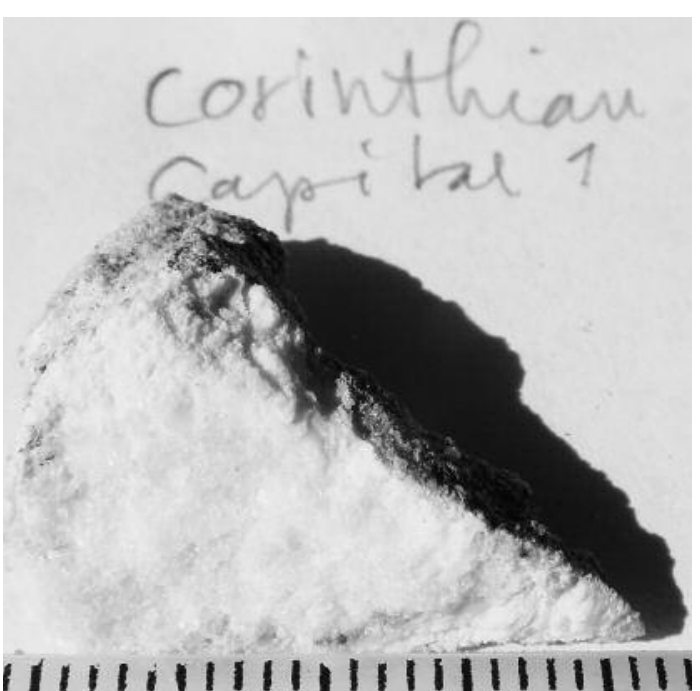

Fig. 33. 


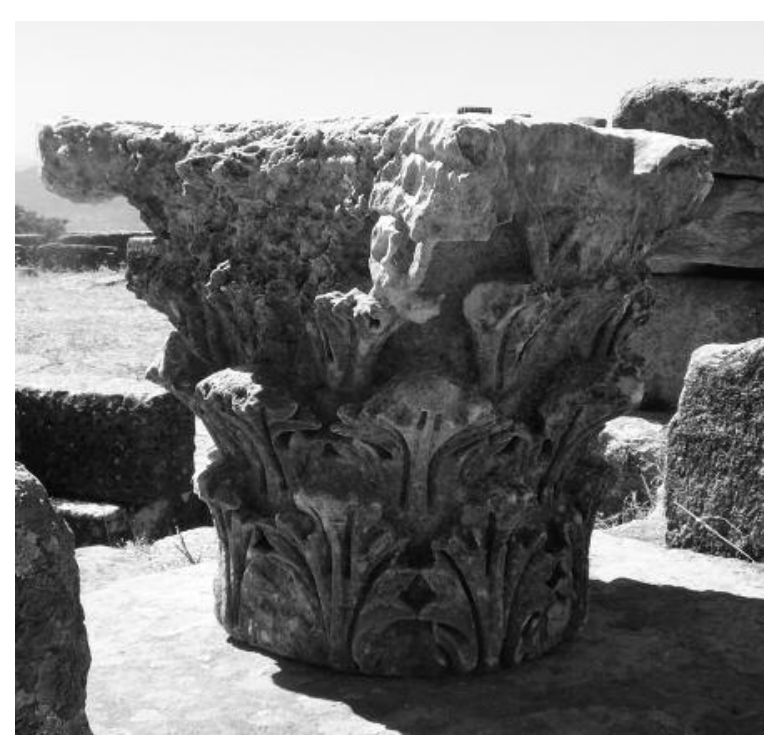

Fig. 34 .

Preliminary results

There is a great similarity between the CorCap samples, which are considered as of the same kind. To this group belong Corcap 1, Corcap 2, Corcap 5, Lab TTsima, and TTarch. All elements are dated to the Roman period (Group 4).

Notes

Ocular observations show a very fine-grained white marble. The surface is weathered and covered with surface deposits such as earth and lichens. All Corinthian capitals seem to have been made from the same type of marble. The capital was conserved by E. Andersson in 2013.

References

Labraunda, North Stoa: Liljenstolpe and von Schmalensee 1996; Hellström 2007: 103-109.

Marble: Freccero, Conservation Report 2013; Cantisani Report 2014; Freccero 2014: 51.

\section{Sample: Lab CorCap 2}

(Fig. 34-35)

Location: North Stoa.

Object: Corinthian capital, inv. B147. jan).

Period: Roman period, Poleites A.D. 102-114 (Tra-

Sampling: September 2012.

Photos: SAM 1091; 9008.

Ocular investigation: Fine-grained white marble.

Analyses

CNR/ICVBC (optical microscopy, mineralogical and petrographic investigation).

Results: Marble with very fine grains.

Mineralogical composition: calcite.

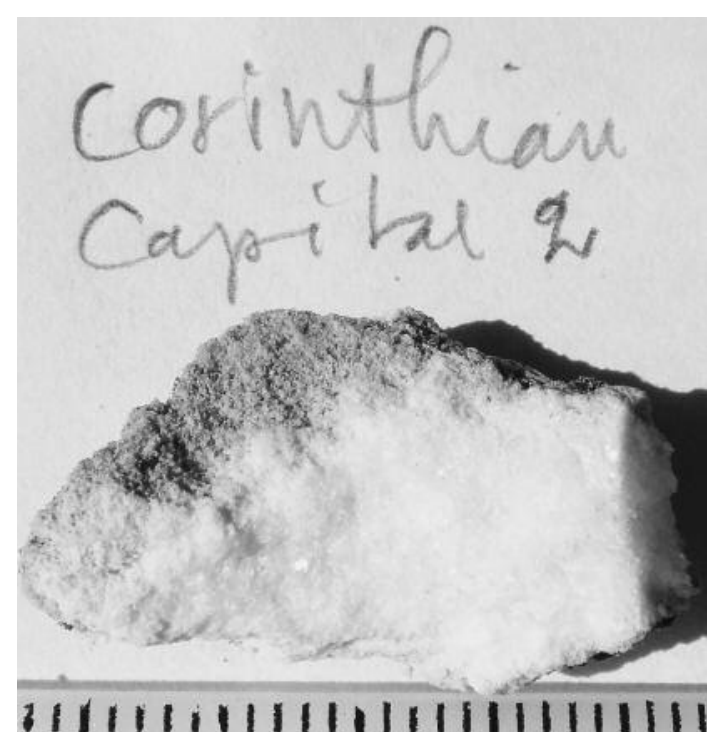

Fig. 35 .

Petrographic description: Granulometry: Maximum: 600 micron; Medium: 200 micron; Minimum: 50 micron.

The crystals have subhedral shape. This sample is characterized by strongly deformed areas and it presents phenomena of alteration. The boundaries between crystals are straight to lobate.

Preliminary results

There is a great similarity between the CorCap samples, which are considered as of the same kind. To this group belong Corcap 1, Corcap 2, Corcap 5, Lab TTsima, and TTarch. All elements are dated to the Roman period (Group 4)

\section{Notes}

Ocular observations show a very fine-grained white marble. The surface is weathered and covered with surface deposits such as earth and lichens. All Corinthian capitals seem to have been made from the same type of marble. The capital was conserved by A. Plahn in 2013.

\section{References}

Labraunda, North Stoa: Liljenstolpe and von Schmalensee 1996; Hellström 2007: 103-109.

Marble: Freccero, Conservation report 2013; Cantisani Report 2014; Freccero 2014: 51.

\section{Sample: Lab CorCap 5}

(Fig. 36-37)

Location: North Stoa.

Object: Corinthian capital, B 141. jan).

Period: Roman period, Poleites A.D. 102-114 (Tra-

Sampling: September 2013.

Photos: SAM 1098-1100; 1342.

Ocular investigation: Fine-grained white marble. 


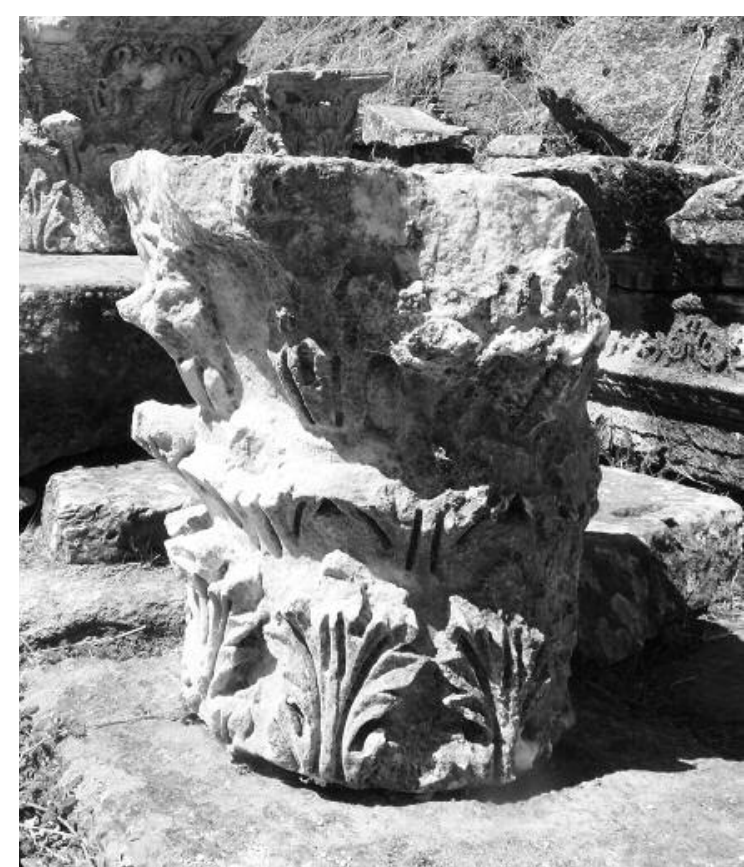

Fig. 36.

Analyses

CNR/ICVBC (optical microscopy).

Results: CorCap 5 is very similar to CorCap1.

Attanasio and Prochaska (Isotopic, EPR, and petrographic analysis).

Results: marble from Milas (A/P: group 1, fine grained samples with MGS below $1.0 \mathrm{~mm}$ ).

Preliminary results

There is a strong similarity between the CorCap samples, which are considered as of the same kind.

To this group belong Corcap 1, Corcap 2, Corcap 5, Lab TTsima, and TTarch. All elements are dated to the Roman period. (Group 4)

Notes

The capital was conserved by A. Enberg in 2013.

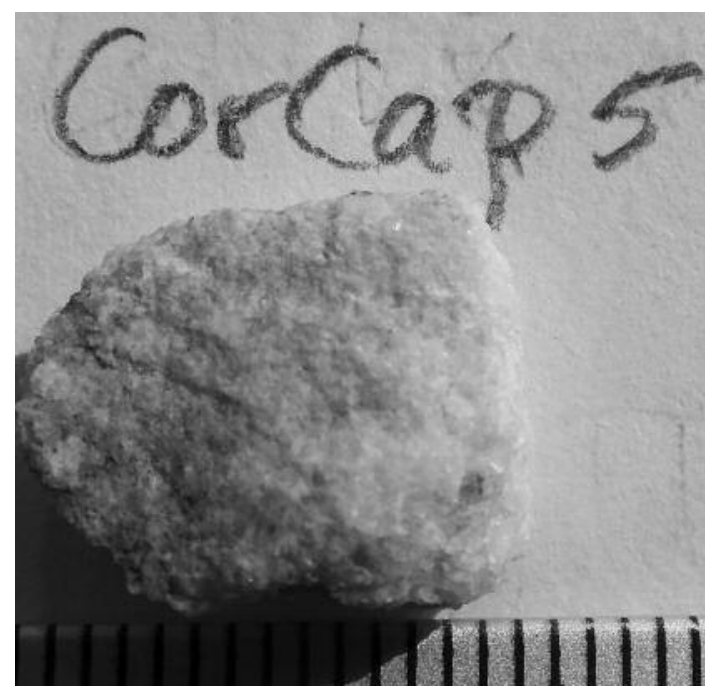

Fig. 37.

References

Labraunda, North Stoa: Liljenstolpe and von Schmalensee 1996; Hellström 2007: 103-109.

Marble: Freccero, Conservation report 2013; Attanasio and Prochaska, Analysis 2014; Cantisani Report 2014.

\section{Sample: Lab DH}

(Fig. 38-39)

Location: Doric house.

Object: Architrave block of the Hekatomnid building, inv. P12.

Period: The inscription of the Hekatomnid period or an addition of the Hellenistic period.

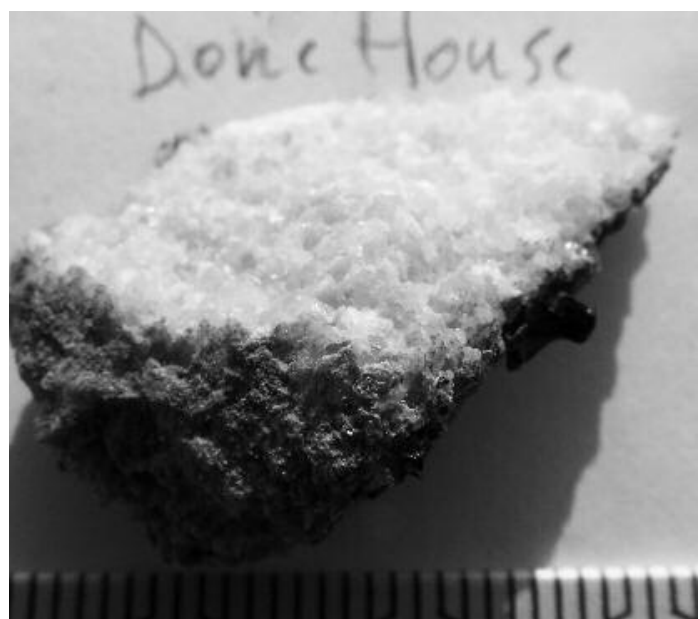

Fig. 39.

Fig. 38. 
Sampling: September 2013.

Photos: SAM 1309-14; 1326. Hard.

Ocular investigation: Coarse-grained white marble.

Analyses

CNR/ICVBC (optical microscopy, mineralogical and petrographic investigation).

Results: Marble with medium-large grains.

Mineralogical composition: calcite. No presence of accessory minerals.

Petrographic description: Granulometry: Maximum:1.8 $\mathrm{mm}$, minimum: 300 micron.

The microstructure is granoblastic, there are only few finer grains. The crystals, of euhedral shape, are not oriented in any preferential way. The prevailing boundaries between crystals is straight, there are triple joints. Single crystals present e twins.

Attanasio and Prochaska (Isotopic, EPR, and petrographic analysis).

Results: marble from Herakleia (A/P: group 2, medium to coarse grained samples with MGS ranging from 1.1 to $3.1 \mathrm{~mm})$.

Preliminary results

Samples LabA3, LabA5, LabAF, LabCol, LabDH, LabOikoi, LabEProp, LabSProp belong to the same group. All samples were obtained at buildings constructed in the period of Idrieus, except for LabCol, for which the date is uncertain. To this group belong samples from quarries at Herakleia (HQ1, HQ2, HQ3) Euromos (EQ) and at the site of Lagina. Labraunda bianco is similar but with finer grains (Group 1).

Notes

According to Hellström the Doric House is probably datable to the period of Idrieus. The interior part was reused in the Roman period. The house got its name by its Doric order. The building may have been a treasury or a fountain house, maybe a nympheum. A dedicatory inscription of Idrieus appears on an architrave block (OM$\mathrm{N} \Omega \mathrm{MY}$ ). The house was rebuilt in successive periods and finally became part of the Late antique complex of the East Church. At the time of sampling I was informed the inscription was in a Roman style.

\section{References}

Labraunda, Doric House: Crampa 1972; Hellström 2007: 74f; 2009: 267ff; Blid 2012: 161-220.

Marble: Attanasio and Prochaska, Analysis 2014; Cantisani Report 2014.

\section{Sample: Lab EProp}

(Fig. 40-41)

Location: East Propylon.

Period: Hekatomnid, $4^{\text {th }}$ century B.C.

Object: Architrave, inv. H11.

Sampling: September 2013.

Photos: 1306-08; 1328.

Ocular investigation: Coarse-grained white marble.

(1-3 mm). Hard.

Analyses

CNR/ICVBC (optical microscopy, mineralogical and petrographic investigation).

Results: Marble with large grains.

Mineralogical composition: calcite. No presence of accessory minerals.

Petrographic description: Granulometry: Maximum: $2 \mathrm{~mm}$, minimum: 400 micron.

The crystals have euhedral shape, and the prevailing boundaries between crystals are straight. There are triple joints. The microstructure is granoblastic, and the crystals, which present typical e twins, are not oriented in any preferential way.

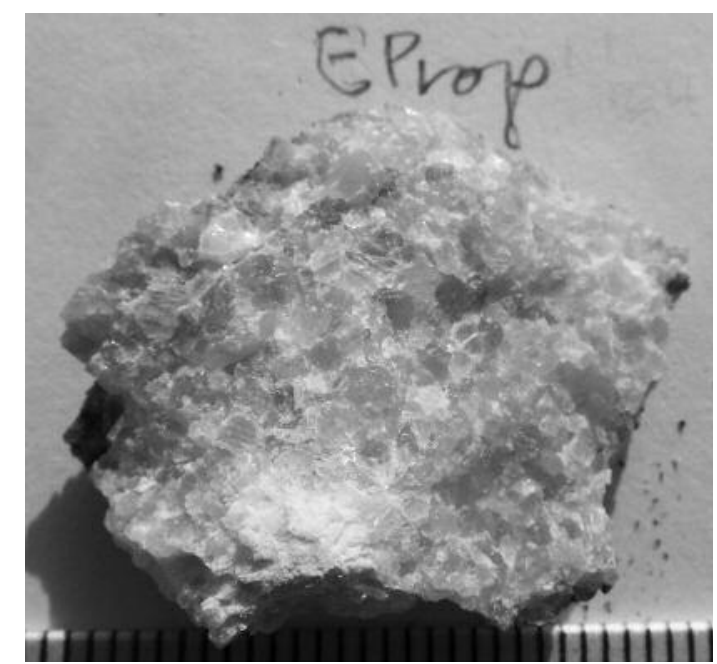

Fig. 41.
Fig. 40.

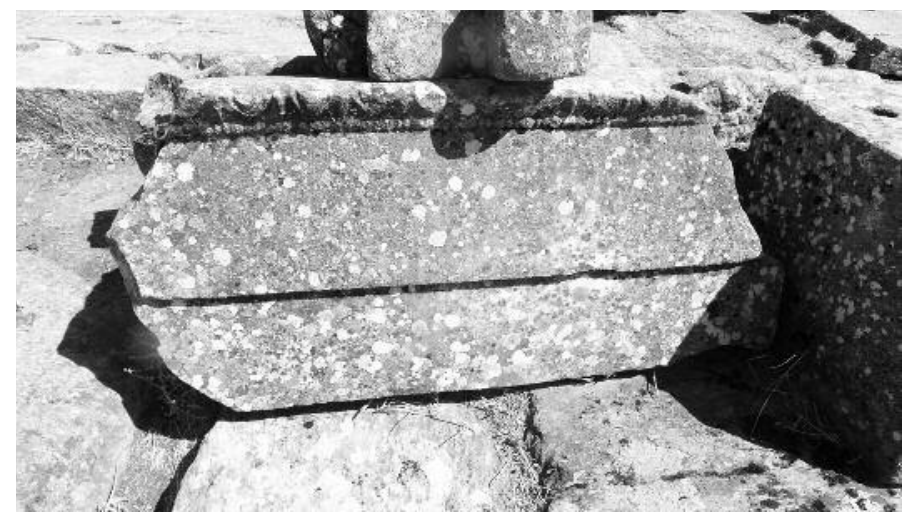


Attanasio and Prochaska (Isotopic, EPR, and petrographic analysis).

Results: marble from Herakleia (A/P: group 2, medium to coarse grained samples with MGS ranging from 1.1 to $3.1 \mathrm{~mm})$.

\section{Preliminary results}

To this group belong samples LabA3, LabA5, LabAF, LabCol, LabDH, LabOikoi, LabEProp, LabSProp belong to the same group. All samples were obtained at buildings constructed in the period of Idrieus, except for LabCol, for which the date is uncertain. To this group belong samples from quarries at Herakleia (HQ1, HQ2, HQ3) Euromos (EQ) and at the site of Lagina. Labraunda bianco is similar but with finer grains. (Group 1)

\section{Notes}

The East Propylon was constructed in the Hekatomnid period, but it has not been possible to date the building exactly. It may be contemporary with the South Propylon.

\section{References}

Labraunda, East Propylon: Jeppesen 1955: 31ff; Hellström 2007: 81.

Marble: Attanasio and Prochaska, Analysis 2014; Cantisani Report 2014.

\section{Sample: LabEx}

(Fig. 42-43)

Location: Temple terrace. B48.

Object: Exedra. Rear side of the central block, inv.

Period: Hellenistic, $3^{\text {rd }}$ century B.C.

Sampling: September 2013.

Photos: SAM 1088, 1005-06; 1341.

Ocular investigation: Fine-grained white marble. Frail
Analyses

CNR/ICVBC (optical microscopy, mineralogical and petrographic investigation).

Results: Marble with varying grain sizes.

Mineralogical composition: calcite. No accessory minerals.

Petrographic description: Granulometry: Maximum: 500 micron. This sample has a variable grain size. The crystals shape is subhedral and the microstructure is slightly oriented. In the areas of medium fine grains the boundaries between crystals varies between straight and slightly lobate.

Attanasio and Prochaska (Isotopic, EPR, and petrographic analysis).

Results: marble from Milas (A/P: group 1, fine grained samples with MGS below $1.0 \mathrm{~mm}$ ).

Preliminary results

Samples LabEx and Lab Yanta are similar and belong to the same group. Both are architectonic elements dated to the Hellenistic period. To this group belong samples BE1, M1, Sodra3 and Sodra4, all obtained south of Milas (Group 6).

Notes

This semicircular building is roughly $4 \mathrm{~m}$ wide and 2 $m$ deep. It consists of a platform on which stand a curved wall and a low bench. The exedra was dedicated by Demetrios Pythonos. The many inscriptions published by Crampa in 1977 are almost completely lost.

\section{References}

Labraunda, Exedra: Crampa 1972; Hellström 2007: 106f; Tobin 2014.

Marble: Attanasio and Prochaska, Analysis 2014; Cantisani Report 2014.

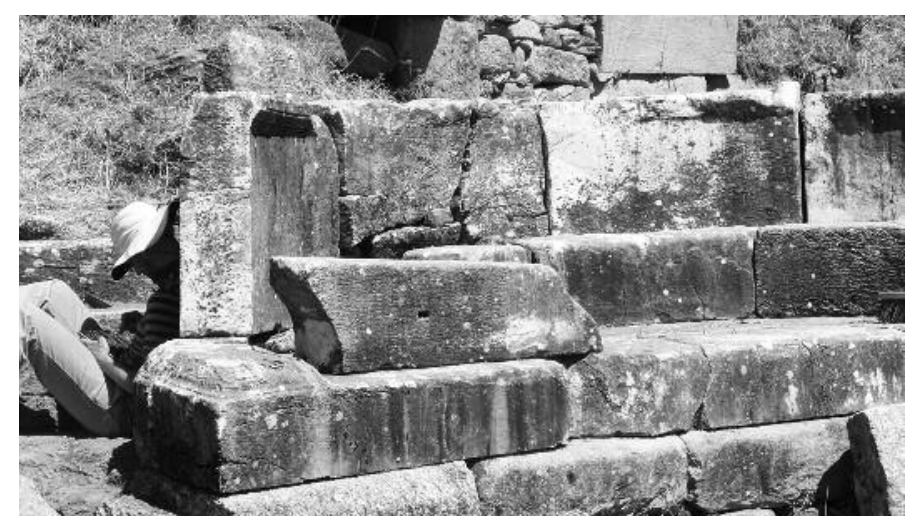

Fig. 42.

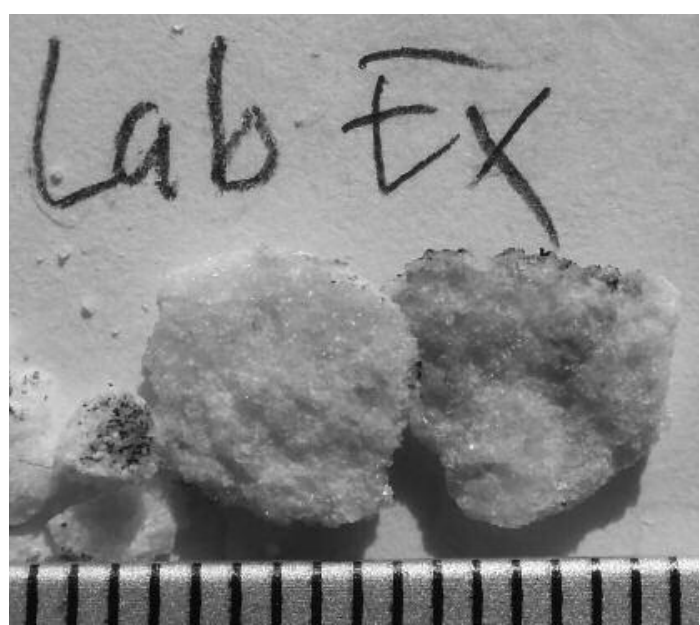

Fig. 43. 


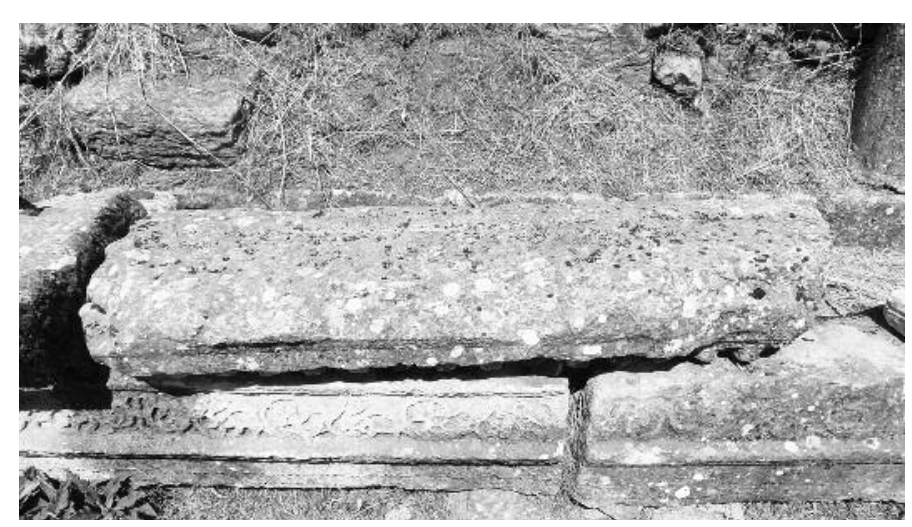

Fig. 44.

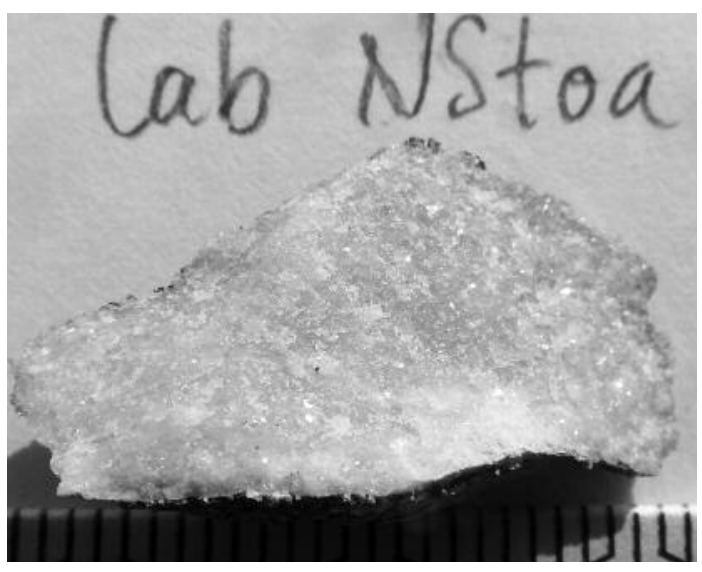

Fig. 45.

\section{Sample: Lab NStoa}

(Fig. 44-45)

Location: North Stoa.

Object: Frieze/architrave.

Period: Roman period, Poleites A.D. 102-114 (Trajanus).

Sampling: September 2013.

Photos: SAM 1276-77, 1292; 1335-36.

Ocular investigation: Fine-grained white marble. Hard.

Analyses

CNR/ICVBC (optical microscopy, mineralogical and petrographic investigation).

Results: Pure calcite marble with medium-fine grains.

Mineralogical composition: calcite. No visible presence of accessory minerals.

Petrographic description: Granulometry: Maximum: 400 micron.

The crystals are subhedral and the prevailing boundaries between crystals are lobate. The crystals seem slightly oriented and the microstructure is elaborated. In some areas the crystals look even finer due to intense disaggregation.

Attanasio and Prochaska (Isotopic, EPR, and petrographic analysis).

Results: marble from Milas (A/P: group 1, fine grained samples with MGS below $1.0 \mathrm{~mm}$ ).

Preliminary results

CNR, under the microscope: The marble of this sample is very much decayed and therefore difficult to determine. It is placed in a group of calcite marbles with accessory minerals and variable microstructure (Group 5).
Notes

The Roman North Stoa was constructed on the still remaining foundations of an earlier stoa dedicated by Maussollos.

\section{References}

Labraunda, North Stoa: Liljenstolpe and von Schmalensee 1006; Hellström 2007: 103ff;

Marble: Attanasio and Prochaska, Analysis 2014; Cantisani Report 2014.

\section{Sample: Lab Oikoi}

(Fig. 46-47)

Location: Oikoi, north of Andron A.

Object: Architrave with dedication, inv. A35. Letters visible on this block are Y $\Sigma \Delta \mathrm{II} \Lambda \mathrm{AMBPAYN} \Delta \Omega$.

Period: Hekatomnid, before 353 B.C.

Sampling: September 2013

Photos: SAM 1296-98; 1338.

Ocular investigation: Coarse-grained white marble (1-2 mm).

\section{Analyses}

CNR/ICVBC (optical microscopy, mineralogical and petrographic investigation).

Results: Marble with large grains.

Mineralogical composition: calcite, traces of quartz. No visible presence of accessory minerals.

Petrographic description: Granulometry: Maximum: $2.5 \mathrm{~mm}$, minimum: 500 micron. The shape of the crystals is euhedral, and the microstructure is granoblastic, with only few finer grains. The crystals are not oriented in any preferential direction. The prevailing boundaries between crystals are straight, and there are triple joints. Single crystals present e twins. 


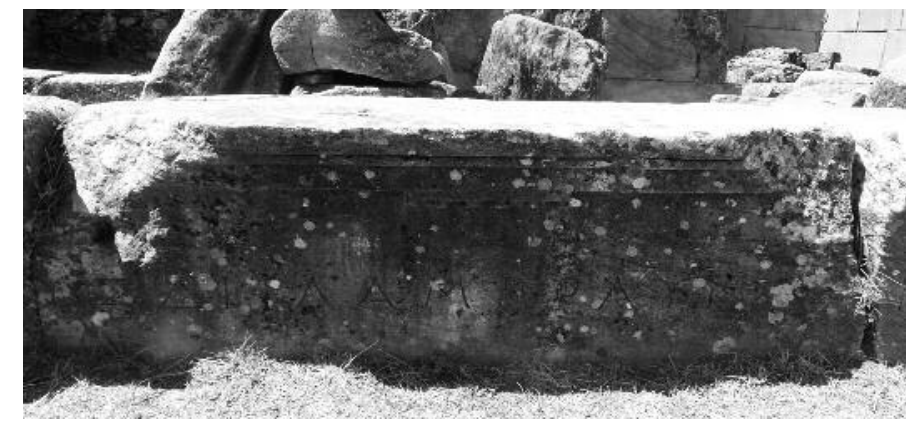

Fig. 46.

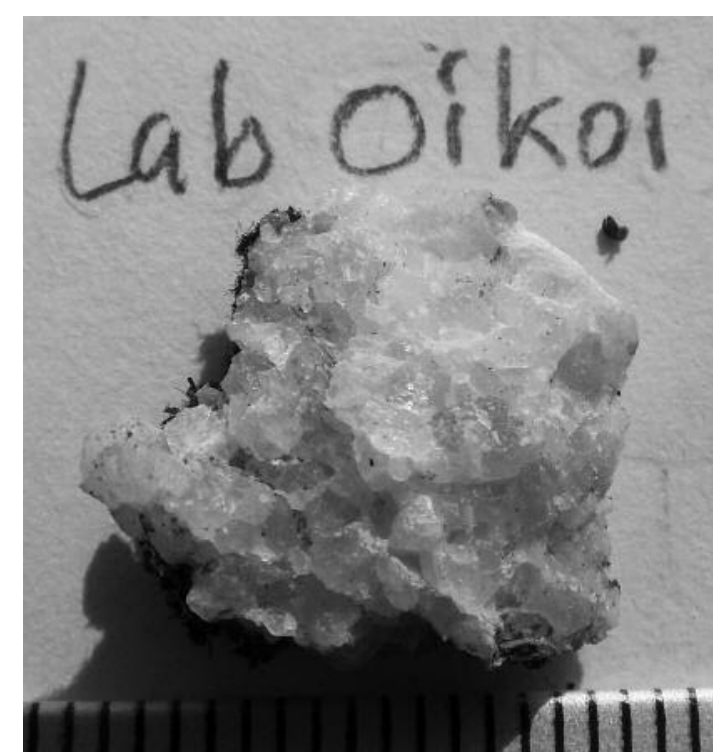

Fig. 47.
Attanasio and Prochaska (Isotopic, EPR, and petrographic analysis).

Results: marble from Herakleia (A/P: group 2, medium to coarse grained samples with MGS ranging from 1.1 to $3.1 \mathrm{~mm})$.

Preliminary results

CNR, under the microscope: Lab Oikoi has the same type of marble as Lab A3 and Lab A5, i.e. the architrave of Andron A, constructed by Idrieus.

To this group belong samples LabA3, LabA5, LabAF, LabCol, LabDH, LabOikoi, LabEProp, LabSProp. All samples were obtained at building constructed in the period of Idrieus, except for LabCol, for which the date is uncertain. To this group belong samples from quarries at Herakleia (HQ1, HQ2, HQ3) Euromos (EQ) and at the site of Lagina. Labraunda bianco is similar but with finer grains (Group 1).

\section{Notes}

The Oikoi building which was maybe begun by Maussollos ca. 353. It was completed by Idrieus who dedicated the building $c a$. 349. The architrave would be a late detail of the building, i.e. compatible with marbles of the period of Idrieus.

\section{References}

Labraunda, Oikoi: Crampa 1972; Hellström and Thieme 1982; Hellström 2007: 119-125; 2011, 154f.; 2015, forthcoming.

Marble: Monna and Pensabene 1977; Attanasio and Prochaska, Analysis 2014; Cantisani Report 2014.

\section{Sample: Lab SProp}

(Fig. 48-49)

Location: South Propylon.

Object: Architrave with dedication. Inv. K81.

Period: Hekatomnid, Idrieus, $c a$. 350-345 B.C.

Sampling: September 2013.

Photos: SAM 1315-17; 1327.

Ocular investigation: White marble with mediumsized grains.

Fairly hard

\section{Analyses}

CNR/ICVBC (optical microscopy, mineralogical and petrographic investigation).

Results:Pure calcite marble with large grains.

Mineralogical composition: calcite. No visible presence of accessory minerals.

Petrographic description: Granulometry: Maximum: $2 \mathrm{~mm}$, minimum: 400 micron.

The crystals are of euhedral shape, and the prevailing boundaries between crystals are straight to slightly lobate, and there are triple joints. The crystals present typical e twins, and the microstructure is oriented in any preferential direction.

Attanasio and Prochaska (Isotopic, EPR, and petrographic analysis).

Results: marble from Herakleia (A/P: group 2, medium to coarse grained samples with MGS ranging from 1.1 to $3.1 \mathrm{~mm})$.

Preliminary results

To this group belong samples LabA3, LabA5, LabAF, LabCol, LabDH, LabOikoi, LabEProp, LabSProp. All 


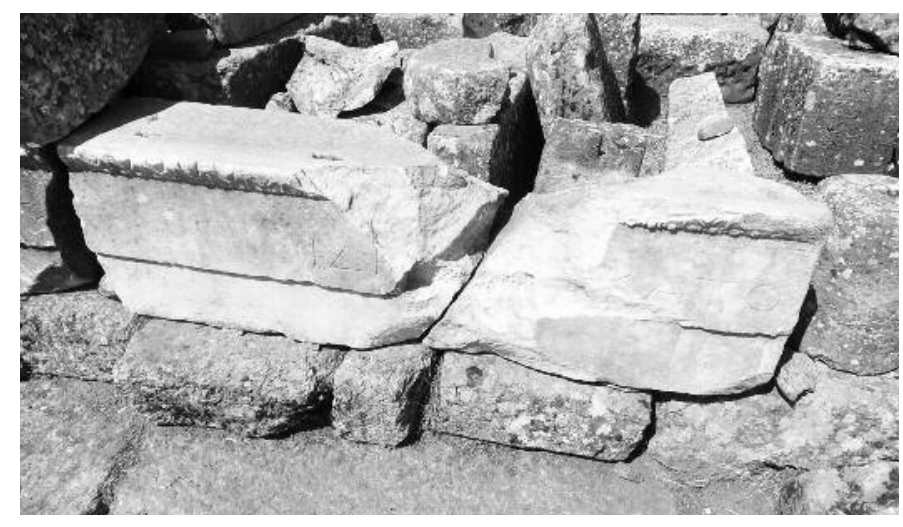

Fig. 48.

samples were obtained at building constructed in the period of Idrieus, except for LabCol, for which the date is uncertain. To this group belong samples from quarries at Herakleia (HQ1, HQ2, HQ3) Euromos (EQ) and at the site of Lagina. Labraunda bianco is similar but with finer grains (Group 1).

Notes

The architrave fragment was conserved by A. Enberg in 2013 .

\section{References}

Labraunda, South Propylon: Jeppesen 1955: 2ff, pl X, fig. 7.

Marble: Freccero, Conservation report 2013; Attanasio and Prochaska, Analysis 2014; Cantisani, Report 2014; Freccero 2014: 48f.

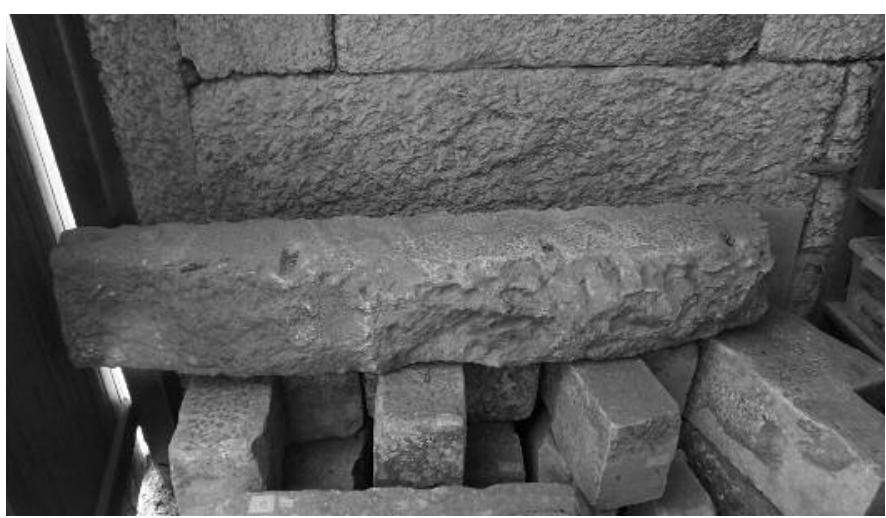

Fig. 50.

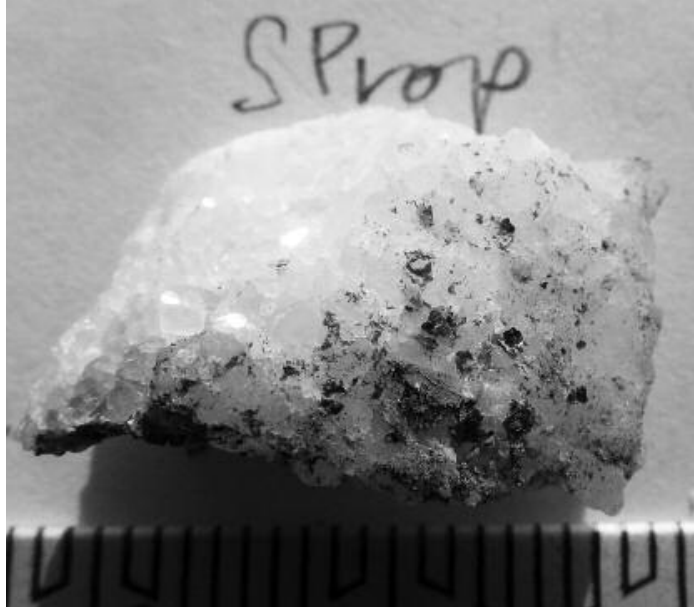

Fig. 49.

\section{Sample: LabTov}

(Fig. 50-51)

Location: Depot. Fragment of the older temple.

Object: Ovolo. Inv. D138.

Period: Late Archaic, $c a .500$ B.C.

Sampling: September 2013

Photos: SAM 1305; 1324.

Ocular investigation: Fine-grained white marble. Very frail and sugaring.

\section{Analyses}

CNR/ICVBC (optical microscopy, mineralogical and petrographic investigation).

Results: Marble with medium-fine grains.

Mineralogical composition: calcite. No accessory minerals.

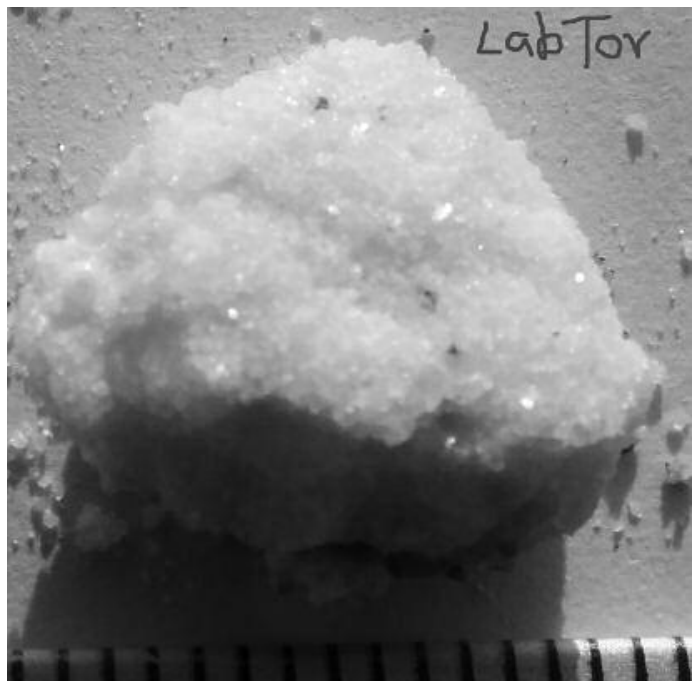

Fig. 51. 
Petrographic description: Granulometry: maximum: 600 micron, minimum 200 micron.

The crystal form is euhedral to subhedral, and the boundaries between crystals are straight to lobate. There are internal deformations in the crystals. The microstructure is deformed.

Attanasio and Prochaska (Isotopic, EPR, and petrographic analysis).

Results: marble from Milas (A/P: group 1, fine grained samples with MGS below $1.0 \mathrm{~mm}$ ).

Preliminary results

Sample LabTov, belongs to the same group as Lab Btomb, a marble slab found at the Monumental Built Tomb. The marbles are similar to HMQ1, HMQ3, and HMQ4, samples from the Miletos quarries (Group 3).

Notes

The archaic temple dated to the $6^{\text {th }}$ century B.C. was extended and rebuilt in the Hekatomnid period, presumably in the period of Maussollos and completed by Idrieus who dedicated the temple. The earlier temple or shrine is evidenced not only by the earliest structures but also by a quantity of Attic black ware figure pottery. This progressive period in Labraunda ends with the battle at Labraunda about 496 during the Ionic revolt.

\section{References} ing.

Labraunda, Old temple: Hellström 2015, forthcom-

Marble: Attanasio and Prochaska, Analysis 2014; Cantisani Report 2014.

\section{Sample: Lab TTarch.}

(Fig. 52-53)

Location: Temple terrace.

Object: Architrave frieze, Type B. Inv. B54.

Period: Roman period (Trajanus).
Sampling: September 2013.

Photos: SAM 1274-75, 1288, 1289; 1334.

Ocular investigation: Fine-grained white marble. Hard.

Analyses

CNR/ICVBC (optical microscopy, mineralogical and petrographic investigation).

Results: Marble with fine grains.

Mineralogical composition: Calcite with traces of dolomite and quarzo.

Petrographic description: Granulometry: Maximum: 300 micron, minimum: 10 micron.

The crystal shape varies from euhedral to subhedral. The marble is disintegrated and has black crusts which are visible in thin sections and the petrographic characteristics are not discernable due to the strong decay. The grain sizes vary from between 10 to 300 micron, in some areas even finer.

Attanasio and Prochaska (Isotopic, EPR, and petrographic analysis).

Results: marble from unidentified cave (A/P: group 3 , which includes three fine grained samples that differ markedly from group 1 for their unusually high $\delta^{13} \mathrm{C}$ (from 5.84 to 6.53 ).

\section{Preliminary results}

Similar to the CorCap samples and to sample LabTTSima. All are architectonic elements which belong to structures dated to the Roman period (Group 4).

Notes

\section{References}

Labraunda, temple terrace: Hellström 2007: 103ff; Blid and Hedlund 2013: 327ff; Blid 2014: 35f.

Marble: Attanasio and Prochaska, Analysis 2014; Cantisani, Report 2014.

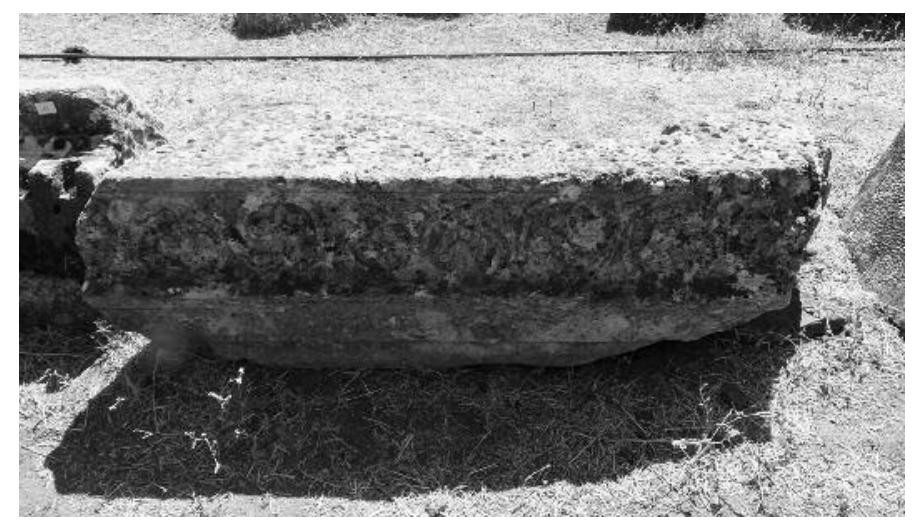

Fig. 52.

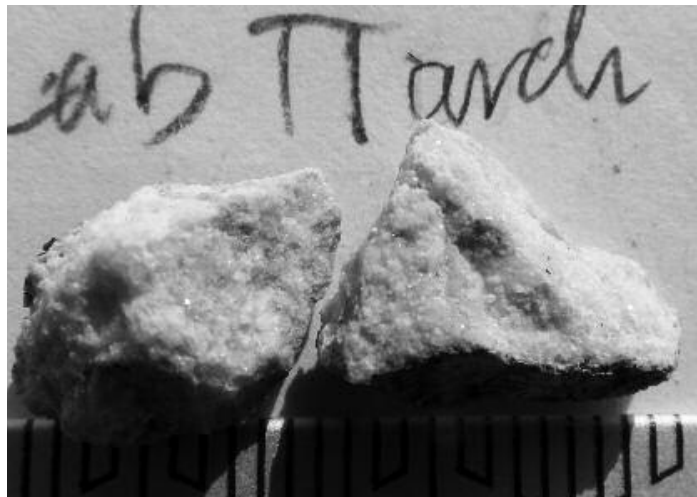

Fig. 53. 


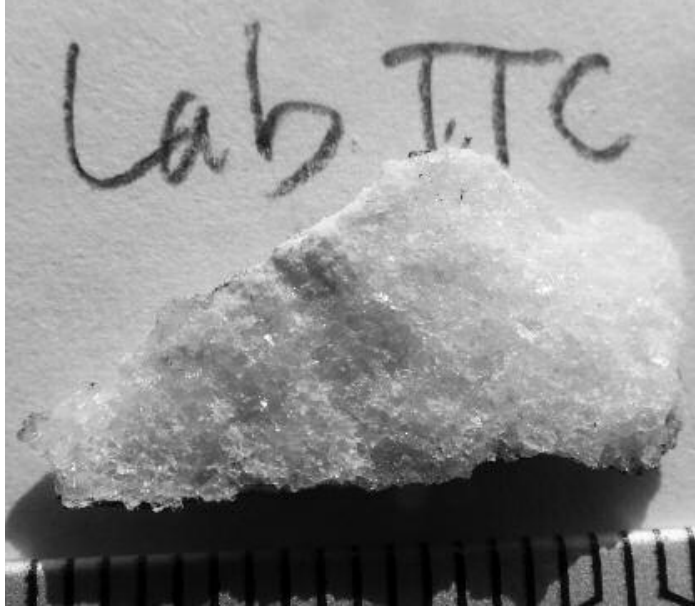

Fig. 54.

\section{Sample: Lab TTC}

(Fig. 54)

Location: Temple terrace.

Object: Architrave/frieze, type C.

Period: Roman, Trajan period.

Sampling: September 2013.

Photos: 1332. Hard.

Ocular investigation: Fine-grained white marble.

Analyses

CNR/ICVBC (optical microscopy, mineralogical and petrographic investigation).

Results: Marble with fine grains.

Mineralogical composition: calcite. No visible presence of accessory minerals.

Petrographic description: Granulometry: Maximum: 500 micron, minimum: 50 micron.

The crystals have varying granulometry, and the shape of the crystals is between euhedral and subhedral. The prevailing boundaries between crystals are straight to slightly lobate and the crystals are not oriented in any preferential way. The marble is disintegrated and has black incrustations that are visible in thin section.

Attanasio and Prochasca (Isotopic, EPR, and petrographic analysis).

Results: marble from Milas (A/P: group 1, fine grained samples with MGS below $1.0 \mathrm{~mm}$ ).

Preliminary results

LabTTC is slightly different to other samples and therefore placed in a group of calcite marbles with accessory minerals and variable microstructure. (Group 5)

Notes

References

Labraunda, Temple terrace: Hellström 2007: 103ff; Blid and Hedlund 2013: 327ff; Blid 2014: 35f.

Marble: Attanasio and Prochaska, Analysis 2014; Cantisani, Report 2014.

\section{Sample: Lab TTcol}

(Fig. 55-56)

Location: Temple terrace.

Object: Column, inv. 179 or 180.

Period: Roman.

Sampling: September 2013

Photos: SAM 1278-79, 1285; 1333.

Ocular investigation: Fine-grained white marble with grey veins. Hard.

Analyses

CNR/ICVBC (optical microscopy, mineralogical and petrographic investigation).

Results:

Mineralogical composition: calcite, traces of quartz, muscovite and chlorite.

Petrographic description: Granulometry: maximum 450 , minimum 250 micron.

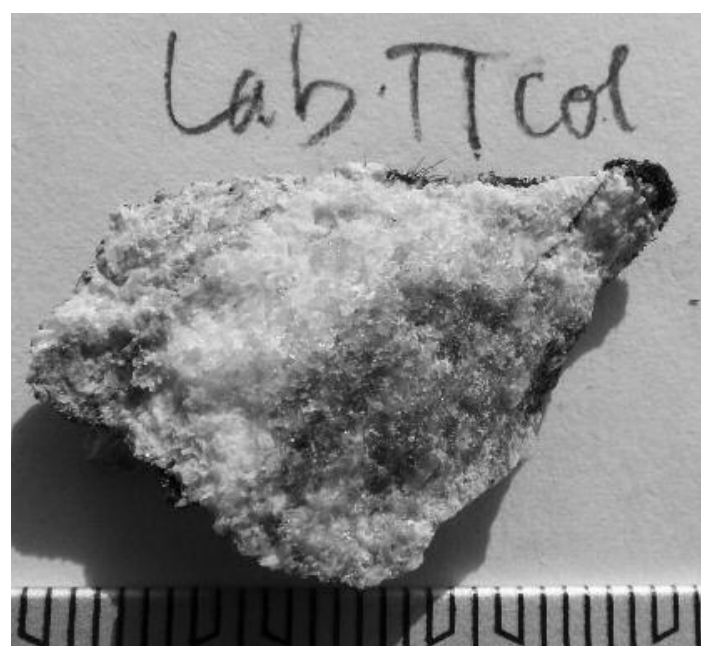

Fig. 56.

Fig. 55. 


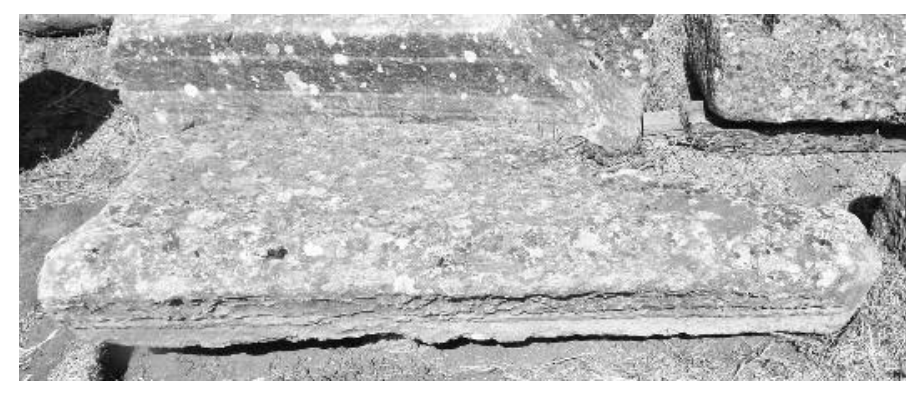

Fig. 57.

Marble with medium sized grains. The crystal shape varies from euhedral to subedral, the boundaries between crystals vary from straight to prevalently lobate. The microstructure is oriented.

There are some areas with accessory minerals such as quartz, muscovite and chlorite.

Attanasio and Prochasca (Isotopic, EPR, and petrographic analysis).

Results: marble maybe an Ephesian marble from the quarry of Tavşantepe (so called Farm Quarry) that is the only one that exhibits such negative oxygen values. No likely alternatives seem to exist. (A/P: group 4, which includes this sample only. The sample differs from any other marble tested for its negative oxygen shift (-8.81).

\section{Preliminary results}

Belongs to the group of different kinds of marble and therefore placed in a group of calcite marbles with accessory minerals and variable microstructure (Group 5).

\section{Notes}

\section{References}

Labraunda, Temple terrace: Hellström 2007: 103ff; Blid and Hedlund 2013: 327ff; Blid 2014: 35f.

Marble: Attanasio and Prochaska, Analysis 2014; Cantisani, Report 2014

\section{Sample: Lab TTsima}

(Fig. 57-58)

Location: Temple terrace.

Object: Sima, inv. B71.

Period: Roman.

Sampling: September 2013.

Photos: SAM 1286-87; 1331.

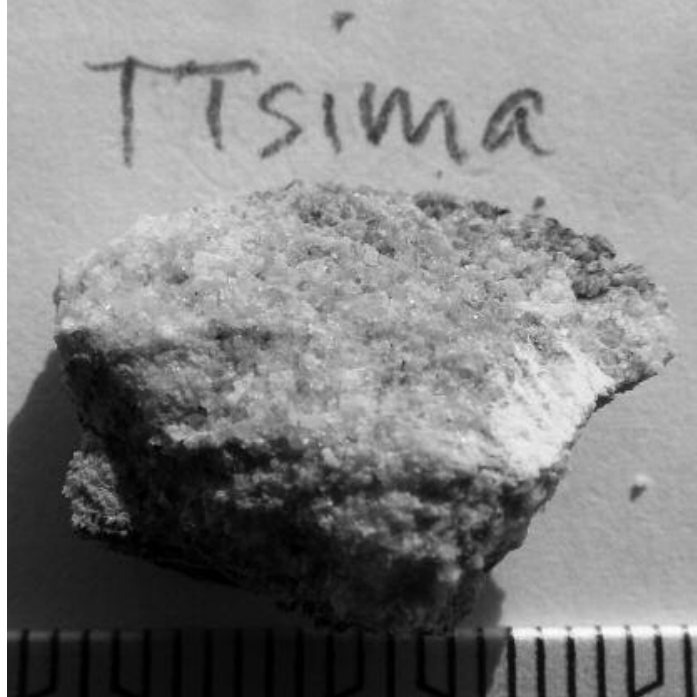

Fig. 58.

Ocular investigation: Medium-grained white marble. Hard. Dirty sample.

\section{Analyses}

CNR/ICVBC (optical microscopy, mineralogical and petrographic investigation).

Results: Marble with zones of fine grains and zones of medium-fine grains.

Mineralogical composition: calcite. There are traces of Dolomite.

Petrographic description: Granulometry: maximum: 500 micron, minimum: micron. The crystals shape in the medium fine area is euhedral and the prevailing shape of the grain boundaries is straight. The crystals are not oriented in any preferential direction. There are a few double twin crystals. In the fine grained zones the characteristics of the grains is impossible to solve under optical microscope.

Attanasio and Prochaska (Isotopic, EPR, and petrographic analysis).

Results: marble from unidentified cave (A/P: group 3 , which includes three fine grained samples that differ markedly from group 1 for their unusually high $\delta^{13} \mathrm{C}$ (from 5.84 to 6.53 ).

Preliminary results

To this group belong samples CorCap 1, Corcap 2, Corcap 5, LabTTsima, Lab TTArch (Group 4).

\section{Notes}

\section{References}

Labraunda, Temple terrace: Hellström 2007: 103ff; Blid and Hedlund 2013: 327ff; Blid 2014: $35 f$.

Marble: Attanasio and Prochaska, Analysis 2014; Cantisani Report 2014. 


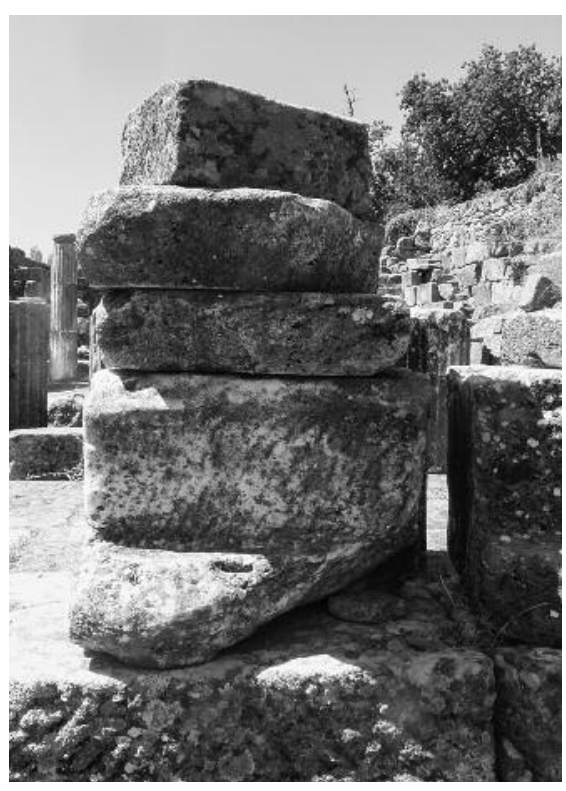

Fig. 59.

\section{Sample: Lab TZeus}

(Fig. 59-60)

Location: Temple of Zeus.

Object: Architrave, inv. D107.

Period: $4^{\text {th }}$ century B.C.

Sampling: September 2013.

Photos: SAM 1299-1300; 1337.

Ocular investigation: Coarse-grained white marble (1-3mm). Frail.

\section{Analyses}

CNR/ICVBC (optical microscopy, mineralogical and petrographic investigation).

Results: Marble with large grains.

Mineralogical composition: calcite. No presence of accessory minerals.

Petrographic description: Granulometry: Maximum: $2 \mathrm{~mm}$, minimum: 500 micron. The crystals have euhedral shape, and the prevailing boundaries between crystals are straight. Single crystals present normal and e twins. Some twins are deformed. The microstructure is granoblastic, only few finer grains

Attanasio and Prochaska (Isotopic, EPR, and petrographic analysis).

Results: marble from Herakleia (A/P: group 2, medium to coarse grained samples with MGS ranging from 1.1 to $3.1 \mathrm{~mm})$.

Preliminary results

Marbles of samples LabA3, LabA5, LabAF, LabCol, LabDH, LabOikoi, LabEProp, LabSProp belong to the same group. All samples were obtained at building constructed in the period of Idrieus, except for LabCol, for

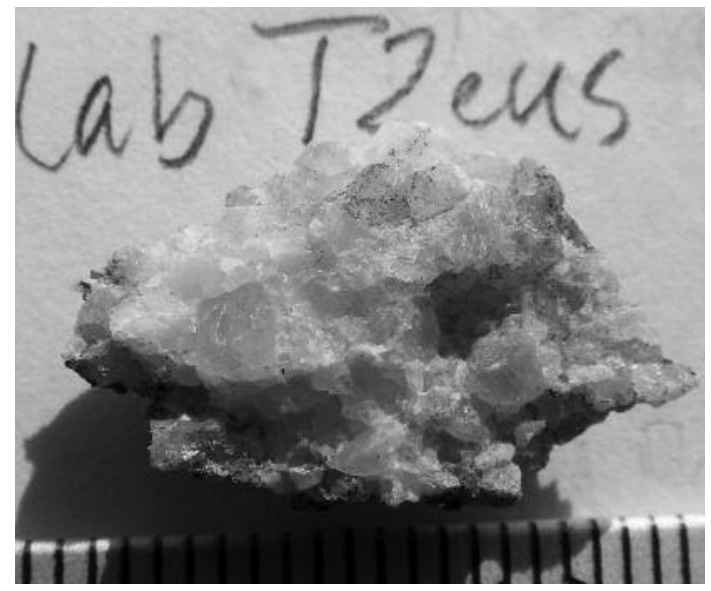

Fig. 60.

which the date is uncertain. To this group belong samples from quarries at Herakleia (HQ1, HQ2, HQ3) Euromos (EQ) and at the site of Lagina. Labraunda bianco is similar but with finer grains (Group 1).

\section{Notes}

The Temple of Zeus was completed in the period of Idrieus. The temple was probably built by the famous architect Pytheos, who had built the Mausoleum at Halikarnassos and the Temple of Athena at Priene. The architrave was conserved by S. Holickova in 2014.

\section{References}

Labraunda, Temple of Zeus: Hellström and Thieme 1982: 78 (E80); Hellström 2007: 111-117; 2015, forthcoming.

Marble: Monna and Pensabene 1977; Attanasio and Prochaska, Analysis 2014; Cantisani Report 2014; Andersson, Conservation report 2014.

\section{Sample: Lab Yanta}

(Fig. 61-62)

Location: Propylon Y

Object: Anta block, inv.Y6.

Period: Hellenistic, $3^{\text {rd }}$ century B.C.

Sampling: September 2013

Photos: SAM 1282-83; 1330.

Ocular investigation: Greyish white marble. Very fine grains. Hard.

Analyses

CNR/ICVBC (optical microscopy, mineralogical and petrographic investigation). 


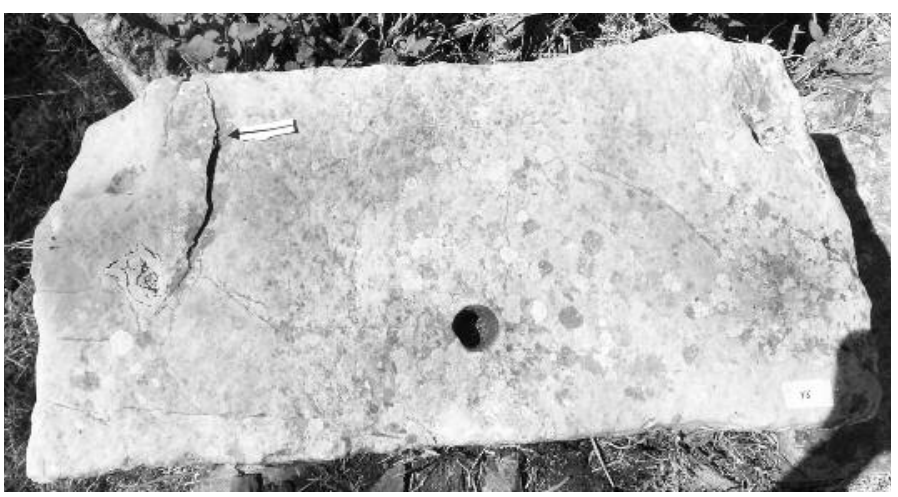

Fig. 61.

Results:

Mineralogical composition: calcite, traces of quartz.

Petrographic description: Granulometry: maximum 400, minimum 50 micron. Marble with medium sized grains. The crystal shape varies from euhedral to subhedral, and the boundaries between crystals vary from straight to lobate. The calcitic crystals present parallel and crossed twins. The microstructure is not oriented and is a "mosaic" micro fabric.

Attanasio and Prochaska (Isotopic, EPR, and petrographic analysis).

Results: marble from Milas (A/P: group 1, fine grained samples with MGS below $1.0 \mathrm{~mm}$ ).

Preliminary results

Samples LabEx and LabYanta belong to the same group. To this group belongs one sample (BE1) from Beçin, and M1 from the plain S of Milas, and samples Sodra3 and Sodra4 from Sodradağ (Group 6).

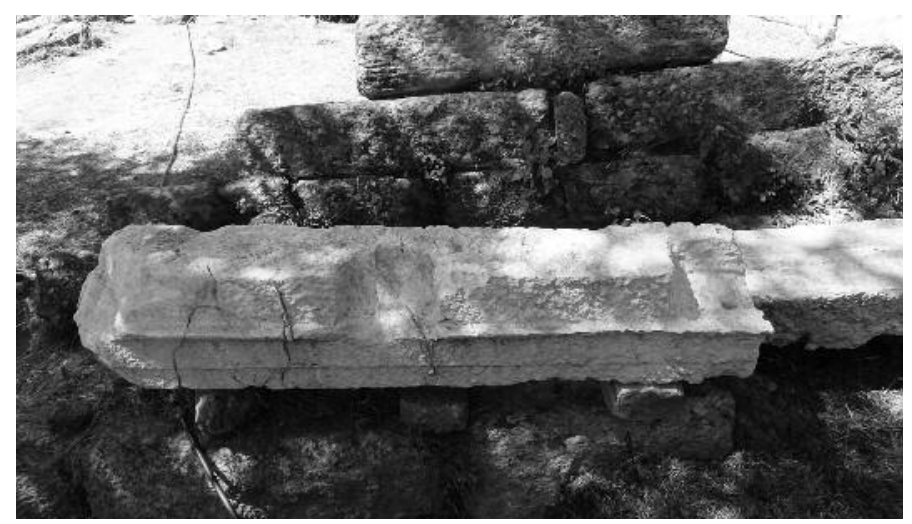

Fig. 63.

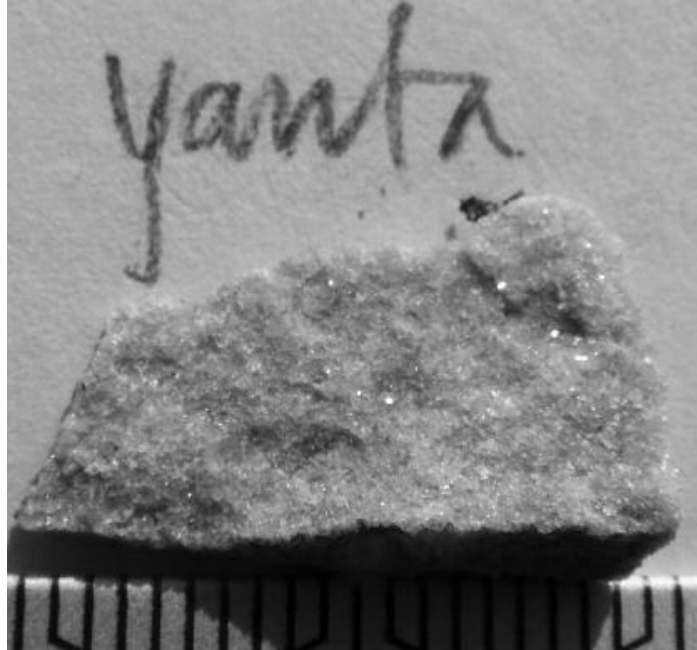

Fig. 62.

Notes

References

Labraunda, Propylon Y: Hellström 2015, forthcoming.

Marble: Attanasio and Prochaska, Analysis 2014; Cantisani Report 2014.

\section{Sample: Lab Yarch}

(Fig. 63-64)

Location: Propylon $\mathrm{Y}$

Object: Architrave, Y21.

Period: Roman.

Sampling: September 2013.

Photos: SAM 1280-84, 1315-17; 1329.

Ocular investigation: White marble with very fine grains. Frail.

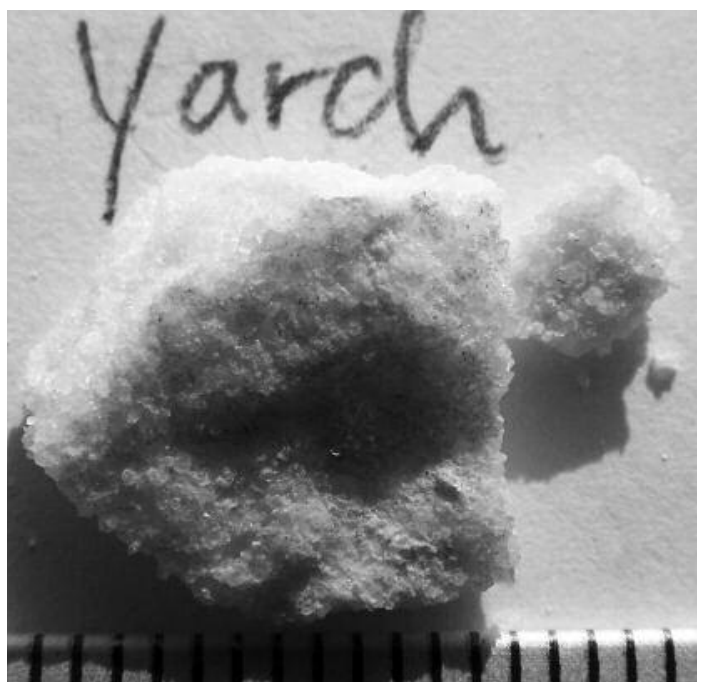

Fig. 64. 


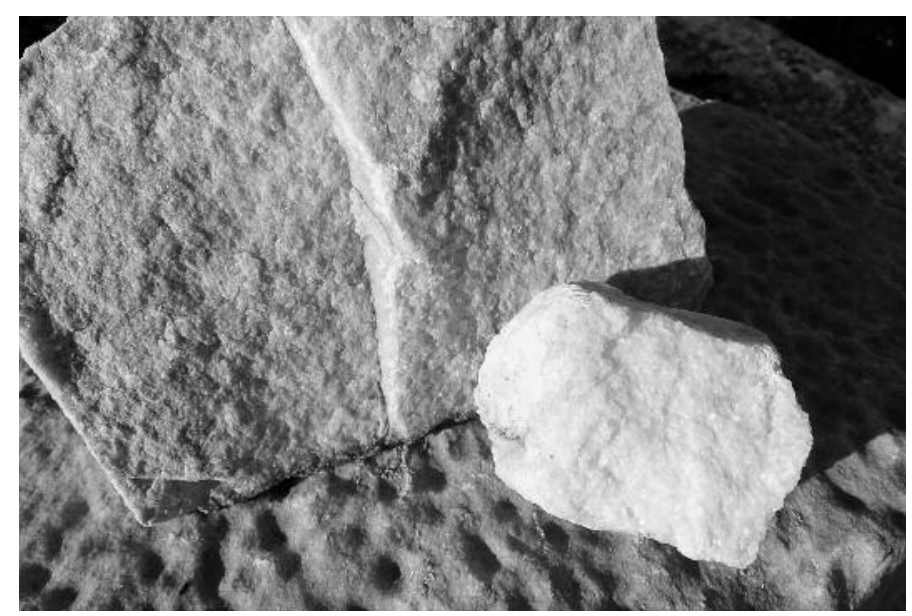

Fig. 65.

Analyses

CNR/ICVBC (optical microscopy, mineralogical and petrographic investigation).

Results:

Mineralogical composition: calcite, traces of quartz and muscovite

Petrographic description: Granulometry: maximum 400, minimum 50 micron.

Marble with a medium-fine grain size. The crystal shape is euhedral, and the boundaries between crystals straight. In thin section the presence of small crystal of micas (muscovite) is evident. The microstructure is not oriented and is a typical granoblastic mosaic micro fabric.

Attanasio and Prochaska (Isotopic, EPR, and petrographic analysis).

Results: marble from unidentified cave (A/P: group 3 , which includes three fine grained samples that differ markedly from group 1 for their unusually high $\delta^{13} \mathrm{C}$ (from 5.84 to 6.53).

Preliminary results

This marble is different from all other samples and therefore placed in a group of calcite marbles with accessory minerals and variable microstructure (Group 5).

\section{Notes}

References ing.

Labraunda, Propylon Y: Hellström 2015, forthcom-

Marble: Attanasio and Prochaska, Analysis 2014; Cantisani Report 2014.

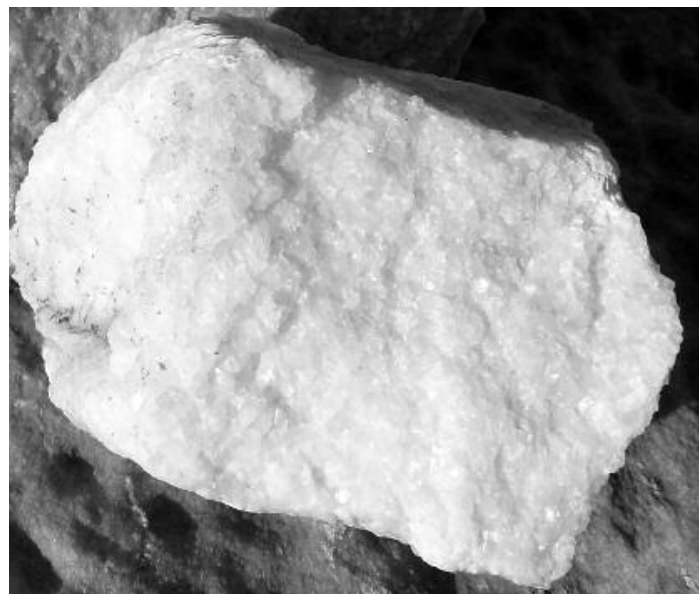

Fig. 66.

\section{Sample: Labraunda white.}

(Fig. 65-66)

Location: Temple terrace.

Object: Loose fragment.

Period:

Sampling: September 2011

Photos: SAM 1868.

Ocular investigation: Coarse-grained white marble.

Analyses

CNR/ICVBC (optical microscopy, mineralogical and petrographic investigation).

Results: Marble with medium-large grains.

Mineralogical composition: calcite, traces of Dolomite. Granulometry:

The marble consists almost only of calcite but there are minor traces of dolomite. The grains are medium/large sized and the granoblastic texture is polygonal.

Preliminary results

Marbles of samples LabA3, LabA5, LabAF, LabCol, LabDH, LabOikoi, LabEProp, LabSProp belong to the same group. All samples were obtained at buildings constructed in the period of Idrieus, except for LabCol, for which the date is uncertain. To this group belong samples from quarries at Herakleia (HQ1, HQ2, HQ3) Euromos (EQ) and at the site of Lagina. Labraunda white is similar but with finer grains (Group 1).

\section{Notes}

References

Marble: Cantisani Report 2014. 


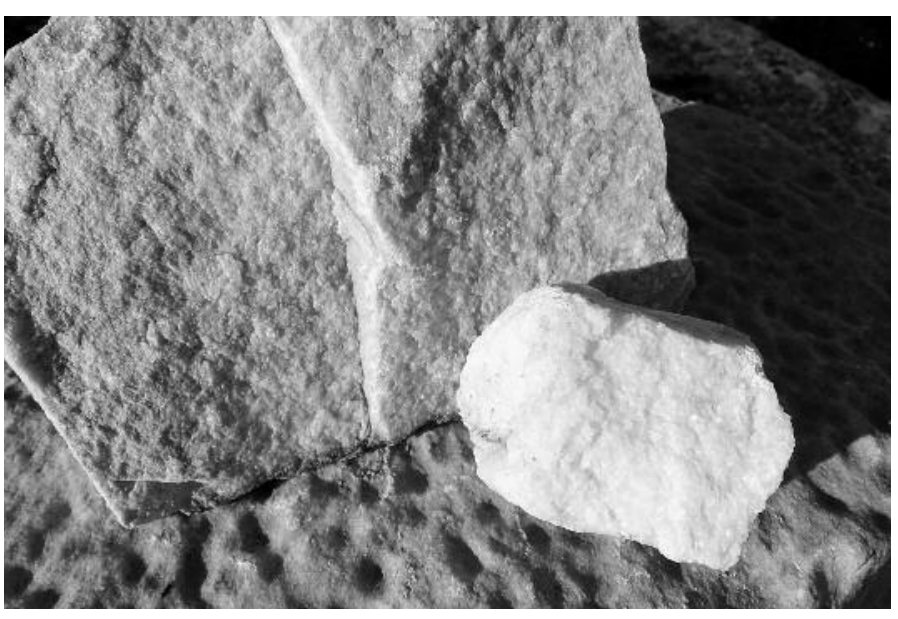

Fig. 67.

\section{Sample: Labraunda grey.}

(Fig. 67-68)

Location: Terrace in front of Andron B.

Object: Fragment of a marble block.

Period:

Sampling: September 2011.

Photos: SAM 1868. marble

Ocular investigation: very fine grained greyish white

Analyses

CNR/ICVBC (optical microscopy, mineralogical and petrographic investigation).

Results: Dolomite marble with fine grains.

Mineralogical composition: Dolomite $\left(\mathrm{Ca}, \mathrm{Mg}\left(\mathrm{CO}_{3}\right)_{2}\right)$ with traces of calcite $\left(\mathrm{CaCO}_{3}\right)$.

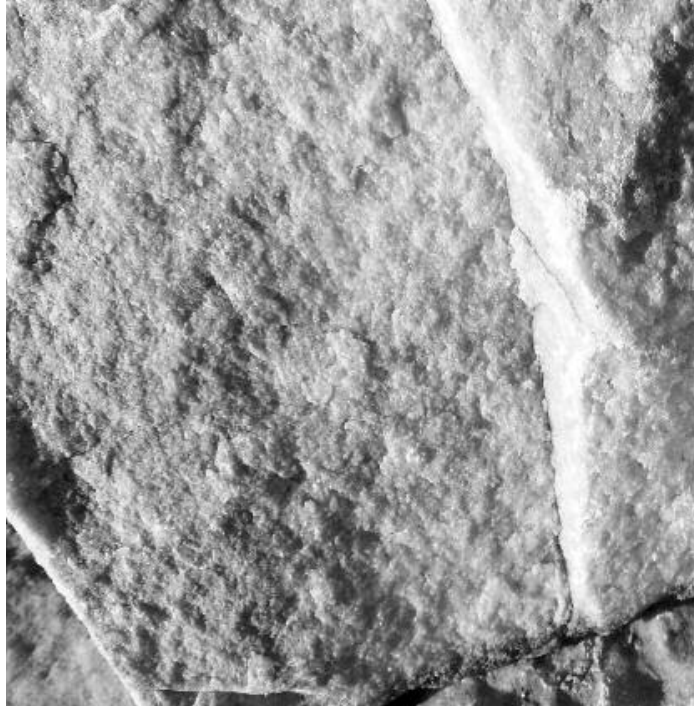

Fig. 68.

\section{Granulometry:}

Preliminary results

Labraunda grigio, Sodra 1 and Sodra 2 are similar. Sodra 1 and 2 were obtained at Sodradağ, SW of Milas, above Gümüşkesen and the Hebrew Cemetery (Group 7).

\section{Notes}

Samples Labraunda grey and Sodra 1 are similar. Both are very fine-grained marbles with veins of larger grains. The mineralogical composition confirms the likeness.

\section{References}

Marble: Cantisani Report 2014. 


\section{BIBLIOGRAPHY}

Aelianus: On Animals.

Andrae, W., 1941: Alte Feststrassen im Nahen Osten, Leipzig.

Attanasio, D., Brilli, M. and Ogle, N., 2006: The Isotopic Signature of Classical Marble, Roma.

Attanasio, D., Bruno, M. and Prochaska, W., 2011: "The Docimium marble of the Ludovisi and Capitoline Gauls and other replicas of the Pergamene dedications", American Journal of Archaeology 115: 1-13.

Attanasio, D., Bruno, M., Prochaska, W. and Bakadir Yavuz, A., 2012: "Aphrodisian marble from the Göktepe quarries: the little Barbarians, Roman copies from the Attalid dedication in Athens", Papers of the British School at Rome 80: 60-87.

Bağcı, M., Kıbıcı, Y., Yıldız, A. and Tezcan Akınc1, Ö., 2010: "Petrographical and geochemical investigation of the Triassic marbles associated with Menderes massif metamorphics, Kavaklıdere, Muğla, SW Turkey", Journal of Geochemical Exploration 107: 39-55.

Barresi, P., 2002: "Il ruolo delle colonne nel costo degli edifice pubblici", in I marmi colorati della Roma imperiale, Venezia: 69-82.

Bean, G. E., 1971: Turkey beyond the Meander, London.

Blid, J., 2012: Felicium Temporum Reparatio. Labraunda in Late Antiquity (c. AD 300-600), Stockholm.

- 2010: "Archaeological investigations at the 'West Church" ", Opuscula 3: 30-51.

Blid, J. and Hedlund, R., 2014: "New research on Labraunda in the Roman Imperial age: The case of the M-terrace", Anatolia Antiqua XXI: 327-336.

Borghini, G. (ed.), 1998: Marmi antichi, Roma.

Brody, L. R., 2007: The Aphrodite of Aphrodisias, Mainz am Rhein.

Bruno, M., 2002: "Considerazioni sulle cave, sui metodi di estrazione, di lavorazione e sui trasporti", in: I marmi colorati della Roma imperiale, Venezia: 179-194.

Carlson, D. N. and Aylward, W., 2010: "The Kizilburun shipwreck and the Temple of Apollo at Claros", American Journal of Archaeology 114: 145-153.

Cramer, T., 2004: Multivariate Herkunftsanalyse von Marmor auf petrografischer und geochemischer Basis, Berlin.

Crampa, J., 1969: The Greek Inscriptions, period of Olympichos, in Labraunda, Swedish Excavations and Research vol III, part I: 1-12, Skrifter utgivna av Svenska Institutet i Athen, 4, V, III.1, Lund.

- 1972: The Greek Inscriptions, in Labraunda, Swedish Excavations and Research vol III, part II: 13133, Skrifter utgivna av Svenska Institutet i Athen, 4, V, III.2, Stockholm.

Durosoy, E. and Altınöz, A. G. B., 2013: "The cultural road between Milas and Labraunda", Anatolia Antiqua XXI: 342-350.

Efe, T., 2007: "The therories of the 'Great Caravan Route' between Cilicia and Troy; The Early Bronze Age
III period in inland Western Anatolia", Anatolian Studies 57: 47-64.

Fant, C., 2013: "Marble use and reuse at Pompeii and Herculaneum; the evidence from the bar", Papers of the British School at Rome 81: 181-209.

Forbes, R. J., 1965: Studies in Ancient Technology, Leiden.

Freccero, A., 2005: Pompeian Plasters. Insula I 9 and Forum, Rome.

- 2007: "Pompeian Plasters", Quaderni di studi Pompeiani 1/2007: 115-126.

- 2008: Pompeian Plasters. Buildings in Regiones I, V, VI, VII, VIII, and IX, Rome.

- 2013: "Marble conservation project", Anatolia Antiqua XXI: 322-327.

- 2015: "The Roman villa at Agios Donatos: Fragments of wall paintings" in: Thesprotia Expedition, Finnish Institute at Athens (forthcoming).

Hedlund, R., 2014: "Antae in the afternoon: Notes on the Hellenistic and Roman Architecture of Labraunda", in: $\triangle A B P Y \Sigma$. Studies presented to Pontus Hellström, Uppsala: $57-70$.

Hellström, P., 2007: Labraunda. A Guide to the Karian Sanctuary of Zeus Labraundos, Istanbul.

- 2011: "Feasting at Labraunda and the chronology of the Andrones", in Karlsson, L. and Carlsson, S. (eds.), Labraunda and Karia, Uppsala:149-157.

- 2015: "Labraunda before the Hekatomids. Excavations on the Temple Terrace 1949-1953", in Henry, O. and Konuk, K. (eds.), Karia Arkana, Istanbul (Forthcoming).

Hellström, P. and Thieme, T., 1982: Labraunda. The Temple of Zeus. Swedish Excavations and Researches, vol.1. Part 3, Stockholm.

Henry, O., 2013a: "La tombe monumentale", Anatolia Antiqua XXI: 301-310.

- 2013b: "A tribute to the Ionian Renaissance", in: $4^{\text {th }}$ Century Karia. Defining a Karian Identity under the Hekatomnids, Paris: 81-90.

- 2014: "Then Whose tomb is that?", in: $\triangle A B P Y \Sigma$. Studies presented to Pontus Hellström, Uppsala.

Herodotos: Herodotos History, translated by A.D. Godley, London 1961-1966.

Jeppesen, K., 1955: The Propylaea, in Labraunda, Swedish Excavations and Researches Vol.I, Part 1, Lund.

Karlsson, L., 2013: "Combining architectural orders at Labraunda: A political statement", in: $4^{\text {th }}$ Century Karia. Defining a Karian Identity under the Hekatomnids, Paris: 65-80.

Liljenstolpe, P. and von Schmalensee, P., 1996: "The Roman Stoa of Poleites at Labraynda", Opuscula Atheniensia XXI: 8.

Marchei, M. C., 1998: Catalogue, in: Marmi antichi, Roma: 247-255.

Monna, D. and Pensabene, P., 1977: Marmi dell'Asia Minore, Roma. 
Niewoehner, P., Audley-Miller, L. and Prochaska, W., 2013: "Marbles, quarries and workshops on the highlands of Northern Macedonia", Archäologischer Anzeiger 2013: 95-145.

Nylander, C., 1970: Ionians in Pasargadae, Uppsala.

Ortolani, G., 1998: "Lavorazione di pietre e marmi nel mondo antico", in: Marmi antichi, Roma: 19-42.

Ökse , A. T., 2007: "Ancient mountain routes connecting Central Anatolia to the Upper Euphrates region", Anatolian Studies 57: 35-45.

Pedersen, P., 2013: "The $4^{\text {th }}$ Century BC 'Ionian Renaissance' and Karian Identity", in: $4^{\text {th }}$ Century Karia. Defining a Karian Identity under the Hekatomnids, Paris: 33-64.

Pensabene, P., 1998: “Amministrazione dei marmi e sistema distributivo nel mondo romano", in: Marmi antichi, Roma: 43-54.

- 2002a: "Il fenomeno del marmo nel mondo romano", in I marmi colorati della Roma imperiale, Venezia: 3-68.

- 2002b: "Le principali cave di marmo bianco", in: I marmi colorati della Roma imperiale, Venezia: $203-$ 222.

Peschlow-Bindokat, A., 1981: "Die Steinbrücke von Milet und Herakleia am Lathmos", Jahrbuch des Deutschen Archäologischen Instituts, Band 96: 157-235.

— 1994: "Steinbruch und Tempel. Die cave di Cusa von Selinunt und die Marmorbrücke von Milet", Antike Welt 25: 122-139.

Plinius: Plinius Naturalis Historiae, translated in English by H. Rackham, Cambridge 1962.

Prochaska, W. and Attanasio, D., 2012: "Tracing the origin of marbles by inclusion fluid chemestry", in: Interdisciplinary studies on Ancient Stone, Tarragona: 230237.
Prochaska, W. and Grillo, S. M., 2012: "The marble quarries of the metropolis of Ephesos and some examples of the use for marbles in Ephesian architecture and sculpting", in: Interdisciplinary studies on Ancient Stone, Tarragona: 584-591.

Rockwell, P., 1993: The Art of Stoneworking, Cambridge.

Söğüt, B., 2011: “Antik Çağda Bir Mermer Şehir: Stratonikeia", Laodikeia Stone 8: 42-47.

Strabo: The Geography of Strabo, translated by H.L. Jones, Cambridge 1950-1954.

Tobin, F., 2014: "The exedra of Demetrios, son of Python, at Labraunda", Opuscula 7: 32-37.

Waelkens, M., De Paepe, P. and Moens, L., 1988: "Patterns of extraction and production in the white marble quarries of the Mediterranean: History, present problems and prospects", in Clayton Fant, J. (ed.), Ancient Marble Quarrying and Trade. Papers from a colloquium held at the annual meeting of the Archaeological Institute of America, San Antonio, Texas, December 1986, Oxford: 81-116.

Walker, S. and Matthews, K. J., 1988: "Recent work in stable isotope analysis of white marble at the British Museum", in Clayton Fant, J. (ed.), Ancient Marble Quarrying and Trade. Papers from a colloquium held at the annual meeting of the Archaeological Institute of America, San Antonio, Texas, December 1986, Oxford: $117-126$

- 1997: "The marbles of the Mausoleum", in: Sculptors and Sculpture of Caria and the Dodecanese, London: 49-67.

Vitruvius: The Ten Books on Architecture, translated by M.H. Morgan, Cambridge 1914. 


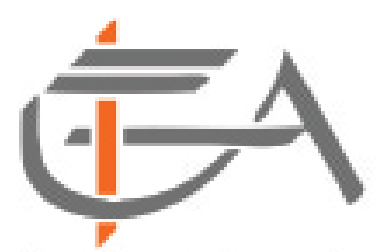

Institut Français d'Etudes Anatoliennes

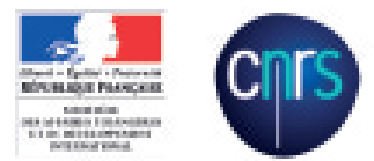

Eglise paléochrétienne de Bindéos (Pisidie), détail de la mosaïque ornant le sal de la nef centrale, $4^{e} \mathrm{~s}$. ap. J.-C. 